San Jose State University

SJSU ScholarWorks

Master's Theses

Master's Theses and Graduate Research

1994

\title{
A crosscultural comparison of the performance of Icelandic children to the norms of U.S. children on the Miller Assessment for Preschoolers : a pilot study
}

Snaefridur Thora Egilson

San Jose State University

Follow this and additional works at: https://scholarworks.sjsu.edu/etd_theses

\section{Recommended Citation}

Egilson, Snaefridur Thora, "A crosscultural comparison of the performance of Icelandic children to the norms of U.S. children on the Miller Assessment for Preschoolers : a pilot study" (1994). Master's Theses. 748.

DOI: https://doi.org/10.31979/etd.bjfp-xjs9

https://scholarworks.sjsu.edu/etd_theses/748

This Thesis is brought to you for free and open access by the Master's Theses and Graduate Research at SJSU ScholarWorks. It has been accepted for inclusion in Master's Theses by an authorized administrator of SJSU ScholarWorks. For more information, please contact scholarworks@sjsu.edu. 


\section{INFORMATION TO USERS}

This manuscript has been reproduced from the microfilm master. UMI films the text directly from the original or copy submitted. Thus, some thesis and dissertation copies are in typewriter face, while others may be from any type of computer printer.

The quality of this reproduction is dependent upon the quality of the copy submitted. Broken or indistinct print, colored or poor quality illustrations and photographs, print bleedthrough, substandard margins, and improper alignment can adversely affect reproduction.

In the unlikely. event that the author did not send UMI a complete manuscript and there are missing pages, these will be noted. Also, if unauthorized copyright material had to be removed, a note will indicate the deletion.

Oversize materials (e.g., maps, drawings, charts) are reproduced by sectioning the original, beginning at the upper left-hand corner and continuing from left to right in equal sections with small overlaps. Each original is also photographed in one exposure and is included in reduced form at the back of the book.

Photographs included in the original manuscript have been reproduced xerographically in this copy. Higher quality $6 "$ " 9 " black and white photographic prints are available for any photographs or illustrations appearing in this copy for an additional charge. Contact UMI directly to order.

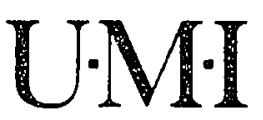

University Microfilms International

A Bell \& Howell Information Company

300 North Zeeb Road. Ann Arbor. MI 48106-1346 USA

$313 / 761-4700 \quad 800 / 521-0600$ 
$\ldots$ 
Order Number 1358172

A crosscultural comparison of the performance of Icelandic children to the norms of U.S. children on the Miller Assessment for Preschoolers: A pilot study

Egilson, Snaefridur Thora, M.S.

San Jose State University, 1994

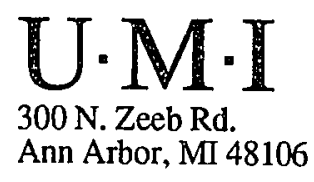



A Crosscultural Comparison of the Performance of Icelandic Children to the Norms of U.S. Children on the Miller Assessment for Preschoolers: A Pilot Study.

\author{
A Thesis
}

Presented to

The Faculty of the Department of Occupational Therapy San Jose State University

in Partial Fulfillment

of the Requirements for the Degree

Master of Science

by

Snaefridur Thora Egilson

May, 1994 
(ㄷ) 1994

Snaefridur Thora Egilson

ALL RIGHTS RESERVED 


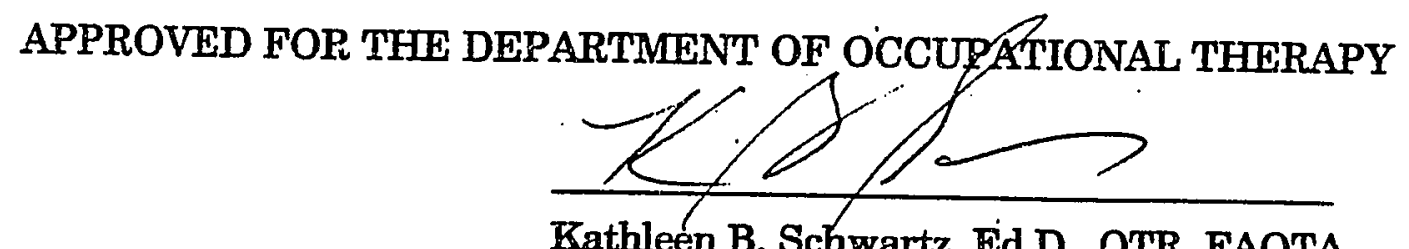

Kathleen B. Schwartz, Ed.D., OTR, FAOTA

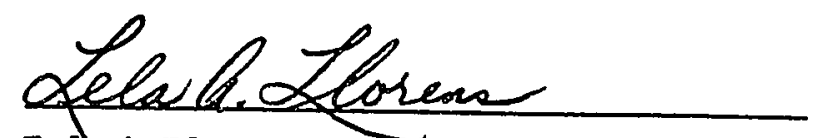

Lelk A. Llorens, Ph. D., OTR, FAOTA

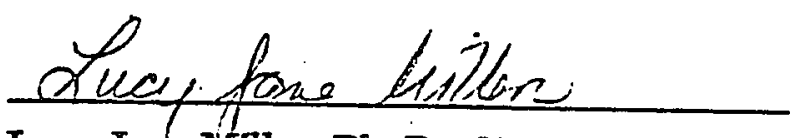

Lucy Jane Miller, Ph. D., OTR

APPROVED FOR THE UNIVERSTTY

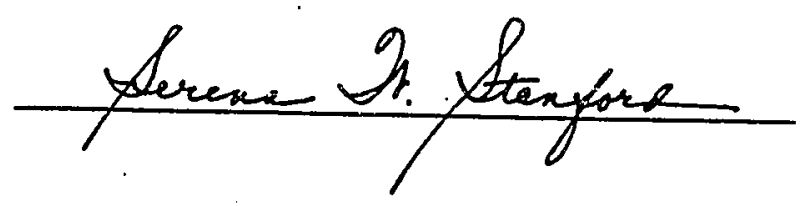




\begin{abstract}
A CROSSCULTURAL COMPARISON OF THE PERFORMANCE

OF ICELANDIC CHILDREN TO THE NORMS OF U.S.

CHILDREN ON THE MLLER ASSESSMENT FOR

PRESCHOOLERS: A PILOT STUDY

by Snaefridur Thora Egilson
\end{abstract}

This study was designed to determine whether differences existed in performance between Icelandic and U.S. children on the Miller Assessment for Preschoolers (MAP).

The MAP was administered to 90 Icelandic children in three age groups of 30 children each. The scores of the Icelandic children were compared descriptively to the U.S. norms on each of the 27 subtests. The results of the study revealed minimal differences in performance on several of the subtests, but noticeable differences on others. This demonstrates the importance of studying the applicability of developmental instruments when using them in a culture different from that which was used to establish the norms. The findings provide a reference point for use of the U.S. norms in Iceland. Further research on the MAP in Iceland is necessary to determine the applicability of the scale for the Icelandic preschool population. 


\section{Acknowledgements}

I would like to thank the many people who assisted with the completion of this study.

To Dr. Kathleen Barker Schwartz, my thesis advisor, my thanks for her time, knowledge and guidance. Special thanks to my thesis reader, Dr. Lela Llorens for her continued support and encouragement, and to Dr. Lucy Jane Miller, the author of the MAP, for her inspiration.

Dr. Bethany Shifflett is acknowledged for her advice on the data analysis.

Appreciation is extended to my colleagues at the State Diagnostic and Councelling Center in Iceland for making this study possible. My deepest thanks to Hlin Gudjondsdottir, OT, for her support with various requests and help with collection of data. And thanks to Sigridur Petursdottir and Gudrun Egilson for their professional advice and help with the translation of parts of the scale.

Last, but not least, I would want to thank all the Icelandic children who participated in the study, as well as their parents for the time set aside for their participation. 


\section{Table of Contents}

Page

CHAPTER 1. INTRODUCTION

$\begin{array}{ll}\text { Purpose } & 1\end{array}$

Statement of the Problem 1

Objective $\quad 2$

Research Question 2

Definitions $\quad 2$

Conceptual Definitions $\quad 2$

Operational Definitions $\quad 3$

Significance of the Study 5

Assumptions 6

Limitations $\quad 6$

CHAPTER 2. REVIEW OF THE LTTERATURE 8

Introduction $\quad 8$

Diagnostic Assessments $\quad 8$

The Miller Assessment for Preschoolers 10

Description 10

Critical Reviews 13

Crosscultural Comparisons $\quad 15$

General Considerations $\quad 15$ 
Reviews of Crosscultural Studies $\quad 17$

$\begin{array}{ll}\text { Summary } & 21\end{array}$

CHAPTER 3. DESIGN AND METHODOLOGY 23

$\begin{array}{ll}\text { Purpose } & 23\end{array}$

Question 23

Research Design 23

Description of the Icelandic Population 23

Sample Selection $\quad 24$

Age and Sex $\quad 24$

Geographic Region and Community Size 24

$\begin{array}{ll}\text { Procedure } & 26\end{array}$

Parent Education and Occupational Level 26

$\begin{array}{ll}\text { Tester Selection } & 27\end{array}$

Development of an Icelandic Translation 27

Administration of the Instrument $\quad 28$

Data Analysis Procedures $\quad 28$

CHAPTER 4. DATA AND RESULTS 31

Introduction $\quad 31$

Demography of the Icelandic Sample 32

Research Findings $\quad 36$

Performance across Age Groups $\quad 64$ 
Age Group II 64

Age Group IV 65

Age Group VI 65

Performance across Indices $\quad 66$

Foundations Index $\quad 66$

Coordination Index $\quad 67$

Verbal Index $\quad 68$

Non-Verbal Index $\quad 69$

Complex-Tasks Index $\quad 70$

$\begin{array}{ll}\text { Question } & 71\end{array}$

$\begin{array}{ll}\text { Conclusion } & 71\end{array}$

CHAPTER 5. SUMMARY, DISCUSSION, IMPLICATIONS, AND RECOMMENDATIONS $\quad 77$

$\begin{array}{ll}\text { Summary } & 77\end{array}$

$\begin{array}{ll}\text { Discussion } & 78\end{array}$

Implications $\quad 84$

Recommendations $\quad 86$

Crosscultural Comparisons $\quad 86$

Study the MAP in Iceland independent of its use in the United States. $\quad 87$

$\begin{array}{ll}\text { References } & 88\end{array}$

vii 


\section{Appendices}

Appendix A: Figures displaying the percentile rank order for the Icelandic and U.S. samples

Appendix B: Content for research at facility

106

Appendix C: Informed consent for subjects

108

Appendix D: Developmental History

113

Appendix E: Letter to Parents

124

Appendix F: Draft for Phoneconversation

with Parents 


\section{List of Tables}

Table

Page

1. Abilities assessed by the MAP

2. Age at time of testing

3. Demographic characteristics of the Icelandic sample

4. Comparison of demographic characteristics of the MAP and Ólafsson's study samples in Iceland

5. Comparison of demographic characteristics of the Icelandic and U.S. Samples

6. Comparison of subtest performance between the Icelandic and U.S. children in age group II

7. Comparison of subtest performance between the Icelandic and U.S. children in age group IV

8. Comparison of subtest performance between the Icelandic and U.S. children in age group VI

9. Differences in subtest performance between the Icelandic and U.S. samples 


\section{List of Figures}

Figure

1. Tower

Page

2. Sequencing

3. Block Designs

4. Block Tapping

5. Stereognosis

40

6. Finger Localization

7. Object Memory

8. Puzzles

9. Figure-Ground

10. Draw-a-Person

11. Motor Accuracy

12. Vertical Writing

13. Hand-to-Nose

14. Romberg

15. Stepping

51

16. Walks Line

52

17. Supine Flexion

53

18. Kneel-Stand 
19. Imitation of Postures

20. Tongue Movements 56

21. Rapid Alternating Movements $\quad 57$

22. Maze 58

23. General Information $\quad 59$

24. Follow Directions $\quad 60$

$\begin{array}{ll}\text { 25. Articulation } & 61\end{array}$

26. Sentence Repetition $\quad 62$

27. Digit Repetition 63

A-1. Reference guide for item score sheet, Icelandic age group Ha 94

A-2. Reference guide for item score sheet, Icelandic age group IIb 95

A-3. Reference guide for item score sheet, Icelandic age group IVa 96

A-4. Reference guide for item score sheet, $\begin{array}{ll}\text { Icelandic age group IVb } & 97\end{array}$

A-5. Reference guide for item score sheet, $\begin{array}{ll}\text { Icelandic age group VIa } & 98\end{array}$

A-6. Reference guide for item score sheet, Icelandic age group VIb 
A-7. Reference guide for item score sheet, U.S. age group IIa $\quad 100$

A-8. Reference guide for item score sheet, U.S. age group IIb 101

A-9. Reference guide for item score sheet, U.S. age group IVa

A-10. Reference guide for item score sheet, U.S. age group IVb

A-11. Reference guide for item score sheet, U.S. age group VIa

A-12. Reference guide for item score sheet, U.S. age group VIb 


\section{CHAPTER 1}

\section{INTRODUCTION}

\section{Purpose}

The purpose of the study was to determine whether there are noticeable differences in subtest performance between Icelandic and U.S. children on the Miller Assessment for Preschoolers (MAP).

\section{Statement of the Problem}

The Miller Assessment for Preschoolers (MAP) is a standardized instrument for the age group 2 years 9 months through 5 years 8 months. It is designed to identify preschool children who are likely to experience school related problems at a later time. It also provides a comprehensive clinical framework to help define a child's strengths and weaknesses and indications for remediation (Miller, 1988a). The MAP has been in use in Iceland for 6 years. As it is used in many settings to differentiate between normal children and children at risk, it is important to determine whether the performance of Icelandic children is similar or different from that of American children since the norms and scoring methodology developed in the United States are also being used. 


\section{Objective}

The objective of the study was to determine whether or not there are noticeable differences in subtest performance between Icelandic preschool children and the U.S. normative data on the Miller Assessment for Preschoolers (MAP).

\section{Research Question}

The question to be answered in the study was:

Are there noticeable differences in subtest performance between Icelandic and U.S. children on the Miller Assessment for Preschoolers (MAP)?

\section{Definitions \\ Conceptual Definitions}

Culture: Patterns of beliefs, values, and behaviors shared by social groups.

Gender: Whether an individual is male or female.

Norm: A standard achievement, represented by the average achievement of a large group of children.

Percentile: The percentage of persons in a sample who scored below a specific raw score. 
Reliability: Consistency or thrustworthiness of measure.

Test Bias: A differential validity of a given interpretation of a test score for any definable, relevant subgroup of test takers.

Test Fairness: How tests are used by the society.

Validity: The extent to which a test measures what it claims to measure.

\section{Operational Definitions}

Icelandic Children: The 90 children who were randomly selected to be representative of the population of Icelandic children aged:

three years three months - three years eight months, four years three months - four years eight months,

five years three months - five years eight months, and participated in this study.

Miller Assessment for Preschoolers: A scale that is designed to evaluate preschool children with mild to severe developmental delays.

Noticeable Difference: Marked patterns and trends that emerge to differentiate the two samples.

Since the purpose of the MAP is to identify children with developmental delays, the distribution of scores is skewed. On many of the subtests the best score a child can receive represents only average 
ability. Therefore, differences within low scores and the way in which the test classifies Icelandic and U.S. children as "at risk" will be used to differentiate. The analysis focuses on the percentages of Icelandic children classified as at risk compared to percentages of U.S. children. Generally, if the number of Icelandic children classified at risk is less than an interval of 10 percentiles compared to U.S. children, the differences are not classified as noticeable. If the differences exceed 10 percentiles, the differences are classified as noticeable. The MAP scoring criteria is based on a color-coded system. A Red score is considerably more extreme than a Yellow score, and has a greater effect on the Total Score. Hence, scores within the Red category weigh twofold relative to scores within the Yellow category when comparing the performance of the two samples.

Preschoolers: Children aged two years nine months through five years eight months.

Subtest Performance: Performance on the 27 subtests of the MAP. U.S. Children: The 1204 children who were randomly selected to be representative of the population of preschool children in the United States during the standardization of the MAP.

U.S. Normative Data: The normative information established for the MAP in the United States. 


\section{Significance of the Study}

When applying a test in a different culture from that which was used to norm the scale, it is accepted that the instrument should be standardized and age norms verified for that culture. For a small nation like Iceland, the process of standardization may become very expensive. Furthermore, a good standardization in itself does not ensure a valid and useful assessment. "A standardization does neither secure the reliability nor the validity of the assessment, but only that a comparison with an external reference exists" (Arnkelsson, 1988, p. 26-27).

If no noticeable differences are found between the samples of the Icelandic children and the U.S. children on the Miller Assessment for Preschoolers in this study, and if the sample is truly representative of the population, it implies that a new standardization in Iceland may not be necessary. "It can be concluded that the U.S. norms are relatively accurate for use in your country and you can use norms already provided in the MAP manual." (Miller, 1983. p. 4). If, however, the results of this study demonstrate noticeable differences in subtest performance between the Icelandic and the U.S. children, it implies that the MAP cannot be administered and scored in Iceland, using the methodology and normative data developed in the U.S.. Therefore, further research and possibly a new standardization in Iceland may be necessary. 
Pediatric occupational therapists in Iceland work at assessment centers, and within the Icelandic school system. There are no standardized Icelandic instruments with which therapists can assess preschool children with developmental delay. The MAP has been the main evaluation tool used by pediatric occupational therapists in Iceland for the past few years. As it is used in many settings to differentiate between normal children and children at risk, it is urgent to determine whether or not the normative information developed in the U.S. can be used for valid decisions about the presence of dysfunction in Icelandic children. This study is the first step toward investigating the applicability of the MAP in Iceland.

\section{Assumptions}

The assumptions held by the researcher are:

1. The sample in the study is representative for Icelandic preschool children within the capital area.

2. If crosscultural differences in development between Icelandic and U.S. children exist, these will be reflected in the study.

\section{Limitations}

The sample size $(\mathrm{N}=90)$ is a limitation as it is usually preferable to have a larger sample. However, a pilot study does not require a large 
sample. Secondly, the sample was not chosen from the entire country, but confined to the capital area where aproximately $60 \%$ of the Icelandic preschool children live. These limitations affect the generalizability of the research. 


\title{
CHAPTER 2
}

\section{REVIEW OF THE LITERATURE}

\begin{abstract}
Introduction
This literature review will initially address diagnostic assessments in pediatrics. Secondly, the MAP will be described and a summary of some of the critical reviews to which the scale has been subjected will be presented. Finally, issues in crosscultural research will be emphasized, followed by discussion of the findings of other crosscultural comparisons on the MAP.
\end{abstract}

\section{Diagnostic Assessments}

"Early identification and early intervention for children with developmental or educational problems have been widely promoted as a valuable responsible approach to serving children with special needs" (Lichtenstein \& Ireton, 1991, p. 488). Diagnostic assessments are commonly used "to determine strengths and limitations, eligibility for special needs programs and services, and possible avenues of remediation" (Miller, 1993, p. 3). The need for reliable and valid tests for the assessment of children who are at risk for developmental dysfunction 
has been identified by authors in numerous disciplines. Campbell (1989) stated that "although standardized tests are continually criticized for labeling, and lack of cultural validity for some groups in the population, such as minorities, they remain the best known means of sorting, classifying, diagnosing, and measuring progress" (p. 3). There is general consensus that "insufficient attention has been focused on the quality of existing instruments used in preschool assessment" (Bracken, 1987, p. 313). It is therefore of utmost importance that practitioners within the field carefully select their instruments, with emphasis on the technical adequacy of the scales in use.

In 1984, McCauley and Swisher identified 10 psychometric criteria compiled from Standards for Educational and Psychological Tests (American Psychological Association) to represent basic information to be considered in the selection of norm-referenced tests. The criteria included: description of the normative sample, adequate sample size, item analysis, the reporting of measures of central tendency and variability, concurrent validity, predictive validity, test-retest reliability and interexaminer reliability.

Miller and Sprong (1986) used those criteria in a psychometric and qualitative comparison of four widely used preschool screening

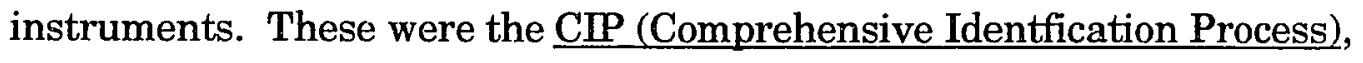


DIAL-R (Developmental Indicators for the Assessment of LearningRevised), DDST-R (Denver Developmental Screening Test) and the MAP. The result indicated that the DIAL-R and the MAP met most of the requirements, the MAP met seven criteria in full. One more criterion, evidence of predictive validity, has since been established.

Within the field of occupational therapy there has long been a lack of objective measurement tools. To date, many of the tests in use in pediatric practice have been developed by professionals other than occupational therapists. However, current trends suggest that therapists are becoming increasingly interested in the use of standardized tests and in conducting research to develop new tests. Only a few of the most commonly used evaluation tools are designed for the preschool age group, and address the range of abilities as the MAP. In recent years the MAP has become popular among pediatric occupational therapists, it is widely used and highly respected.

The Miller Assessment for Preschoolers (MAP)

\section{Description}

Miller Assessment for Preschoolers (MAP) is a standardized instrument for the age group two years nine months - five years eight months. It is designed to provide a statistically sound assessment 
procedure that may be used to identify preschool children with mild to severe delays, and who need further evaluation. In addition, it provides a "comprehensive structured clinical framework to identify a child's strenghts and weaknesses, and to indicate possible avenues of remediation" (Miller, 1988a, p.2). The 27 subtests of the MAP are divided into five Performance Indices:

1. Foundations: Basic motor tasks and the awareness of sensation

2. Coordination: Combination of more complex sensory and motor components.

3. Verbal: Language skills.

4. Non-Verbal: Reasoning skills.

5. Complex Tasks: Combination of sensory, motor and cognitive abilities.

Each Index falls into one of the three types of developmental abilities assessed by the test: Sensory and motor abilites, cognitive abilities, and combined abilities. Some subtests may fall into more than one Index. Abilities assessed by the MAP are listed in Table 1. 
Table 1

Abilities assessed by the MAP

Abilities Assessed $\quad$ Performance Index $\quad$ Number of Subtests in Index

$\begin{array}{lll}\text { Sensory and Motor } & \text { Foundations } & 10\end{array}$

\begin{tabular}{lll} 
& Coordination & 7 \\
Cognitive & Verbal & 4 \\
& Non-Verbal & 5 \\
Combined & Complex Tasks & 4 \\
\hline
\end{tabular}


Norms for the MAP Total Score and Performance Index Scores are expressed in terms of percentiles. A color-coded system is used to indicate whether a child is functioning in the normal or delayed range. The color classifications can be defined as follows:

Red: The child's performance is at or below the 5th percentile rank. The child appears to need further evaluation.

Yellow: The child's performance is in the 6th to 25 th percentile ranks. The child should be watched carefully for developmental delays.

Green: The child's performance is at or above the 25th percentile rank. The child appears to be functioning at an average or above-average level.

The MAP is the result of several years of research involving over 4,000 children and 800 items. The instrument was designed to contain a sufficient number of easy items so that the final score would distinguish among average, low average, and severely dysfunctional groups. Specific patterns of scores among dysfunctional groups that can serve as guidelines to generate hypotheses about performance, have been described by the author (Miller, 1988b).

\section{Critical Reviews}

The MAP has been subjected to numerous critical reviews by experts 
in the areas of psychometrics and child development. These reviews have presented balanced critiques of the strengths and limitations of the scale, and generally they have been favorable. In general, professionals who have used the MAP find the scale to be useful and reliable. "Critical opinion and research evidence to date suggest that the MAP is psychometrically well developed and clinically useful" (Daniels \& Bressler, 1990, p. 49). DeGangi (1983) was critical of the test; however, as data that compared scores and score patterns of the functional delay group with the normative sample were not provided at that time. "Without this information it is difficult to determine the effectiveness of the MAP in screening children with functional delays" (p. 408).

Since 1983, three predictive validity studies have been completed, (Miller \& Lemerand, 1986; Miller, Lemerand, \& Cohn, 1987) that support the MAP's validity. However, Miller (1988a) suggests that more work needs to be completed on the predictive validity of the MAP.

Schouten and Kirkpatrick (1993) stated that the reviews of the studies that evaluated the test's predictive accuracy were overly optimistic and "far more positive than was warranted by the data" (p. 17). They called attention to the risk of underreferral, especially the 5\% cutpoint when the MAP is used as a preschool screening tool. Humphry and King-Thomas (1993) partly agree with Schouten and Kirkpatrick 
on the issue of risk of underreferral when focusing on the respective cutpoint. However, they stressed other important features of the MAP, such as depth of item development, and contribution of unique information about children with developmental delays. Furthermore, they stated that when the MAP is used with observations, it is an excellent tool to "identify the child's current strengths and needs, ...for planning intervention and documenting change" (p. 46).

A review in Buros ${ }^{\prime}$ The Ninth Mental Measurements Yearbook concluded: "The MAP appears to be the best available screening test for identifying preschool children with moderate 'preacademic problems' ...it is short, carefully designed and well standardized...and will quite likely play a major role for many years" (Deloria, 1985, pp. 975-976).

\section{Crosscultural Research}

\section{General Considerations}

Extreme care must be taken when transferring standardized tests between cultural environments, as the norms may differ. "Each culture encourages and fosters certain abilities and ways of behaving, and discourages or suppresses others" (Anastasi, 1988, p. 358). The differences may affect all areas of development, as the normative rates at which children acquire social, linguistic,-and motor skills can vary 
across cultures. There is a growing interest in crosscultural research on psychomotor development in children. However, it is often difficult to compare data across cultures as the methods used and conditions under which the data are collected differ substantially (Wolanski, 1987). Furthermore, it can be questioned if what is being measured by a test is developmentally universal or specific. This requires attention to the comparability of a test within different cultural groups. Validity and reliability studies are important in establishing whether the psychometric characteristics of a test differ significantly in samples from populations that were not included in the standardization population (Jensen, 1980). Fairness to children of different sociocultural, racial, and language background is a particularly important consideration in preschool assessment. Hence, professionals must ensure that an instrument is psychometrically adequate for children of diverse backgrounds when applying it in a different culture than that which was used to establish the norms. If differences between groups exist, one must then determine whether the differences are a function of reality or of error in the test (test bias). According to Gregory (1992), a test should be considered biased if it is differentially valid for different subgroups. 


\section{Reviews of Crosscultural Studies}

A crosscultural comparison by Williams and Williams (1987) of the norms on the DDST, which were developed in Denver (USA), MetroManila (Philippines), Tokyo, Okinawa (Japan), and the Netherlands showed considerable differences in performance. According to the author of the study, "the differences obtained among the crosscultural comparisons may be explained by variables related to age, culture, and child socialization and training. Socioeconomic level is also a possible explanatory variable" (p. 47). Kaplan and Dove (1987) studied Ache children of Eastern Paraguay. Their results suggest that although the Aches followed the same sequence of developmental stages, they acquired some developmental skills at a much slower rate than did American children. Mardell-Czudnowski, Chien-Hou and Tien Miau (1987) studied differences between American and Chinese children on the Dial-R in Taiwan. Their findings imply that the skill development of the Taiwan children is similar to that of American children, with some notable exceptions, some of which develop earlier in Chinese children, others develop earlier in American children. Saeki, Clark and Azen (1985) found differences in performance between the U.S. normative sample and groups of Japanese and Japanese-American children in a study on the Design Copying and Motor Accuracy-Revised Tests of the Southern 
California Sensory Integration Tests. The authors suggested that the differences may be associated with the effects of certain Japanese cultural practices on fine motor ability. In this study, the raw data on the U.S. normative sample were unavailable, and the published average scores were used for the comparison. This procedure may limit the value of the study.

As children from differing cultures develop at different rates, using a set of norms from one culture in different culture can easily misrepresent the child's developmental status. A pilot study in Iceland on the Bayley Scales of Infant Development, showed that the Icelandic study group scored significantly higher than the U.S. standardization sample on the mental scale, while the difference was only marginal and not significant for the motor scale. (Sæmundsen, Halldórsson \& Arnljótsdóttir, 1990). "The results of this study stressed the need to conduct research on developmental tests, when they are moved from one cultural environment to another" (p. 17). This pilot study was conducted on children in the age groups of 6,8 and 10 months. There is general consensus that after 2 years of age, the environmental factors become even more significant.

Frankenburg, Dodds, Fandal, Kazuke and Cors (1970) found no marked difference in the ages at which children of different occupational groups performed on the DDST during the first 2 years of life. After age 2 
years the children of families of higher socioeconomic status performed a number of the language items at an earlier age than those of families of a lower socioeconomic status. A further comparison by Frankenburg, Dick. and Carland (1980) on the functioning level of development for infants and preschool aged children of differing socioeconomic status and ethnic groups in Denver, demonstrated similar results. After 20 months of age, children in a cross-sectional sample were advanced in comparison to children of unskilled laborers in all test sectors except for the personal-social sector. While keeping the occupation group constant, differences between ethnic groups showed less variation in rates of development.

According to the author of the MAP, Dr. Lucy Jane Miller, only a few countries have undertaken a crosscultural study on the scale. The most advanced study was undertaken in Japan, and in 1989 a Japanese version of the Miller Assessment for Preschoolers (JMAP) was published in Japan, preceded by several pilot studies (Tsuchida, 1992). The test is a revised version of the MAP. The authors found it necessary to change half of the subtests in items and five of the subtests in test materials. The main reasons for these changes were different language culture, a difference of passing rates and importance of cultural familiarity for children.

Normative data from selected subtests were used to compare the 
performance of Japanese and US children. Only 9 subtests were selected "because these were the only subtests in which the item's normative data were collected in exactly the same manner as in the MAP" (p. 38).

Significant differences in score distribution among the groups were found in a few of the subtests, especially regarding eye-hand coordination, where Japanese children performed better. These results seem to support findings by Saeki, Clark and Azen (1985) on fine motor ability measured on Japanese and U.S. children by selected subtests of the Southern California Sensory Integration Tests.

Furthermore, Tsuchida compared JMAP score patterns among a Japanese dysfunctional population to MAP score patterns that are based on an U.S. dysfunctional population. Eight different score patterns emerged, on the JMAP whereas six were found to be basically similar to the U.S. score patterns reported by Miller (1988b). These findings imply that the patterns may have cross-cultural validity.

A crosscultural comparison has also been undertaken in Israel on age groups II and VI (Schneider, Parush, Katz, \& Miller, 1993). Despite differences in performance on several of the subtests, no significant differences between the two samples in either age group were found on the MAP Total Score, or on four out of five Performance Indices. However, Israeli children performed at a significantly lower level than the U.S. 
sample on the Foundations Index. The results indicate that the overall performance of Israeli children is not significantly different from the performance of U.S. children on the MAP. In a few other countries similar studies are in process, but nothing has been published thus far. As the Miller Assessment for Preschoolers is designed for the age group 2.9-5.8 years, it is important to verify the norms when using the test outside the United States.

\section{Summary}

Use of reliable, valid instruments has become a high priority for the profession of occupational therapy. Few standardized instruments address the sensory, neurodevelopmental, motor, and perceptual aspects of behavior, which are of concern for therapists working with children. The Miller Assessment for Preschoolers (MAP) is a highly respected and widely used scale, intended to evaluate preschool children with supspected preacademic problems.

The review of the literature suggests that differences in child development exist across cultures. These differences may be explained by variables related to culture, age, child socialization and training. Socioeconomic status is also an explanatory variable. Therefore, using a set of norms from one culture in another culture, has the potential to mis- 
represent a child's true developmental status. If developmental differences across cultural groups exist, then such differences may affect childrens ${ }^{\prime}$ performance on the MAP. This study is designed to provide a reference point for use of the U S. norms of the MAP to Icelandic children. It is the first step in an investigation of the applicability of the scale in Iceland. 


\title{
CHAPTER 3
}

\section{DESIGN AND METHODOLOGY}

\begin{abstract}
Purpose
The purpose of the study was to determine whether there are noticeable differences in performance between Icelandic and U.S. children on the Miller Assessment for Preschoolers (MAP).
\end{abstract}

\section{Question}

The study was designed to answer the following question:

Are there noticeable differences in subtest performance between Icelandic and U.S. children on the Miller Assessment for Preschoolers (MAP)?

\section{Research Design}

The design can be classified as test or instrument assessment research. This was a pilot study, non-experimental research, as there was no manipulation involved.

\section{Description of the Icelandic Population}

The population of Iceland is approximately 260,000 and relatively 
homogenous in cultural and ethnic/racial terms. Everyone speaks the same language. Approximately $60 \%$ of the population lives in the capital area (Reykjavík and suburbs), and $80 \%$ of Icelandic preschool children live within 70 miles radius from Reykjavik. The rest of the population lives in small villages and farms, spread mainly along the coast.

\section{Sample Selection}

\section{Age and Sex}

The sample consisted of 90 children in three age groups, 30 children aged three years three months - three years eight months, 30 children aged four years three months - four years eight months, and 30 children aged five years three months - five years eight months. Age at the time of testing was determined by rounding to the nearest month of age. (See Table 2).

\section{Geographic Region and Community Size}

Geographically, the study was confined to the capital area, where approximately $60 \%$ of Icelandic preschool children live, according to the Icelandic Census Bureau. The test population was chosen from Reykjavík and five neighbour-communities, and randomized and stratified by the Icelandic Census Bureau, according to age, sex, and size of residential community. 
Table 2

Age at Time of Testing

\begin{tabular}{ccc}
\hline Age group & Age range & Median age \\
\hline 2 & $3: 3-3: 8$ & $3: 6$ \\
4 & $4: 3-4: 8$ & $4: 6$ \\
6 & $5: 3-5: 8$ & $5: 6$ \\
\hline
\end{tabular}

Each age group included 15 boys and 15 girls. 


\section{$\underline{\text { Procedure }}$}

A list of prospective children was compiled by the Icelandic Census Bureau. Parents were informed about the study by phone and asked for their consent (Appendix F). If they gave a permission for their child to participate, they were sent a packet including a letter (Appendix E), a consent form (Appendix C), a list of questions regarding the child's health, and some biographical information (Appendix D). A stamped addressed envelope was attached to each packet, but parents were also given the option of returning the forms when they brought in their child for testing. The information was gathered to determine whether the sample was truly representative for the population intended. The study excluded children who exhibited noticeable physical, mental or emotional impairment, did not speak Icelandic as their first language, and who did not live at home. If a parent was reluctant to have his/her child tested, the child was dropped from the sample and the next child on the random list was selected. Day care organizers in the respective communities were contacted and gave their permission for testing of respective children at their day care centers, if the parents so wished.

\section{$\underline{\text { Parent Education and Occupational Level }}$}

Information on socio-economic variables, such as education and 
professional category of mother and father was gathered to further describe the sample. Educational status and occupation were determined by a self-report from the parents of participating children. Taxonomy of parents' occupation was performed according to procedures established by University of Iceland, Department of Social Studies (Ólafsson, 1990).

\section{Tester Selection}

Two occupational therapists, including the researcher, participated in the study. Both had pediatric and standardized testing experience, including several years of experience in the use of the MAP. Both testers completed the MAP procedure reliability checklist prior to testing. Furthermore, detailed instructions in the test manual regarding test administration and scoring procedures and a video training tape, helped to insure good interrater reliability.

\section{Development of an Icelandic Translation}

Parts of the tests (Verbal Index, Item Score Sheets and Behavior

during Testing) had already been translated prior to the undertaken of this study. The subtests in the Verbal Index were adjusted with a consultation from a speech pathologist to secure the qualitative evaluation of the translation. As a part of this study, a blind-back review was performed on 
the Verbal Index by a professional translator and necessary modifications made. Furthermore, other parts of the translation were adjusted. The translation was approved by other occupational therapists in Iceland who are familiar with the test.

\section{Administration of the Instrument}

The testing took place in a three weeks period, (August 18 September 5, 1993). The children were tested either at the researcher's place of work, State Diagnostic and Counselling Center (SDCC) in Iceland, or at the child's day care center, according to the parents' convenience. 80 children were tested at SDCC and 10 children at their preschool setting. Testing time per child was approximately 35-40 minutes. Prior to testing each child, an emphasis was put on establishing good rapport. The subtests were administered in the order in which they appeared in the manual and on the score sheets, except when a variation in the order was believed to facilitate a child's performance. The "Behavior during Testing" checklist was completed after testing each child.

\section{Data Analysis Procedures}

Analysis of the data was performed by the researcher, under guidance of a measurement consultant. The statistical software used to 
analyze the data was SPSS. As the raw scores for the U.S. standardization sample were unavailable, a statistical analysis of the differences between the U.S. and Icelandic samples was not possible. Hence, a descriptive comparison was made with the large random U.S. sample of 1204 children for each of the 27 subtests. The raw scores of the Icelandic children in each age group were converted to percentile ranks to enable a comparison to the normative data of the U.S. children of the same age group. The analysis focused on the percentages of Icelandic children classified as "at risk" compared to percentages of U.S. children. If the number of Icelandic children classified as "at risk" was less than an interval of 10 percentiles compared to the number U.S. children in the same category, the differences were not classified as noticeable. If the differences exceeded 10 percentiles, they were classified as noticeable. The MAP scoring criteria is based on a color-coded system. A Red score is more extreme than a Yellow score, and has a greater impact on the Total Score. Hence, scores within the Red category weighed twofold relative to scores within the Yellow category when comparing the performance of the two samples.

Descriptive statistics were also used to analyze the demographic characteristics of the subjects. A comparison of parents' occupations was made to the Ólafsson (1990) study on socioeconomic status in Iceland, and 
parent's occupation and professional level of the Icelandic and the U.S. standardization sample were also compared. 


\section{CHAPTER 4}

\section{DATA AND RESULTS}

\section{Introduction}

This chapter presents the data and the results of the study. The findings are presented as they relate to the question to be answered in this research: Are there noticeable differences in subtest performance between Icelandic and U.S. children on the Miller Assessment for Preschoolers (MAP)? Data are presented in both narrative and table form.

Analysis of the differences in subtest performance between the two samples focused on noticeable patterns and trends that emerged to differentiate the two samples. The purpose of the MAP is to identify children with developmental delays, and thus skewed distribution of final scores facilitates this process. The test has a large number of items that discriminate between mild and severe delays, but it does not distinguish between high-scoring examinees. On many of the subtests the best score a child can receive represents only average ability. Therefore, differences within low scores and how the test classified Icelandic and U.S. children as "at risk" according to the Red and Yellow cutoff points were emphasized in this study. No color was assigned to the Icelandic children, as further 
research is necessary to determine whether these are appropriate and valid for use in Iceland.

\section{Demography of the Icelandic Sample.}

The demographics of the study sample were examined. Table 3 presents the demographic characteristics of the population tested. Very few parents were reluctant to have their child tested. Hence, retrition from the sample was minimal and nothing implied that it was systematic.

Table 4 presents a comparison of parents' occupation to the Ólafisson study of 1990. The study that described standards and ways of living in Iceland, is commonly used as a reference point on socioeconomic status in Iceland. It appears that there are more parents with managerial and professional jobs in the MAP study sample, and that laborers are less common than in the Ólafsson study. Other professional levels appear to be similarly represented in the two samples. A possible explanation is that the Ólafsson study was confined to the whole country, but the MAP study was confined to the capital area only.

A comparison to the U.S. standardization sample was also performed; however, it is limited by the fact that in the MAP manual, parent's education and professional levels are noted for head of household only. Table 5 presents a comparison of the demographic characteristics of 
Table 3

Demographic characteristics of the Icelandic sample.

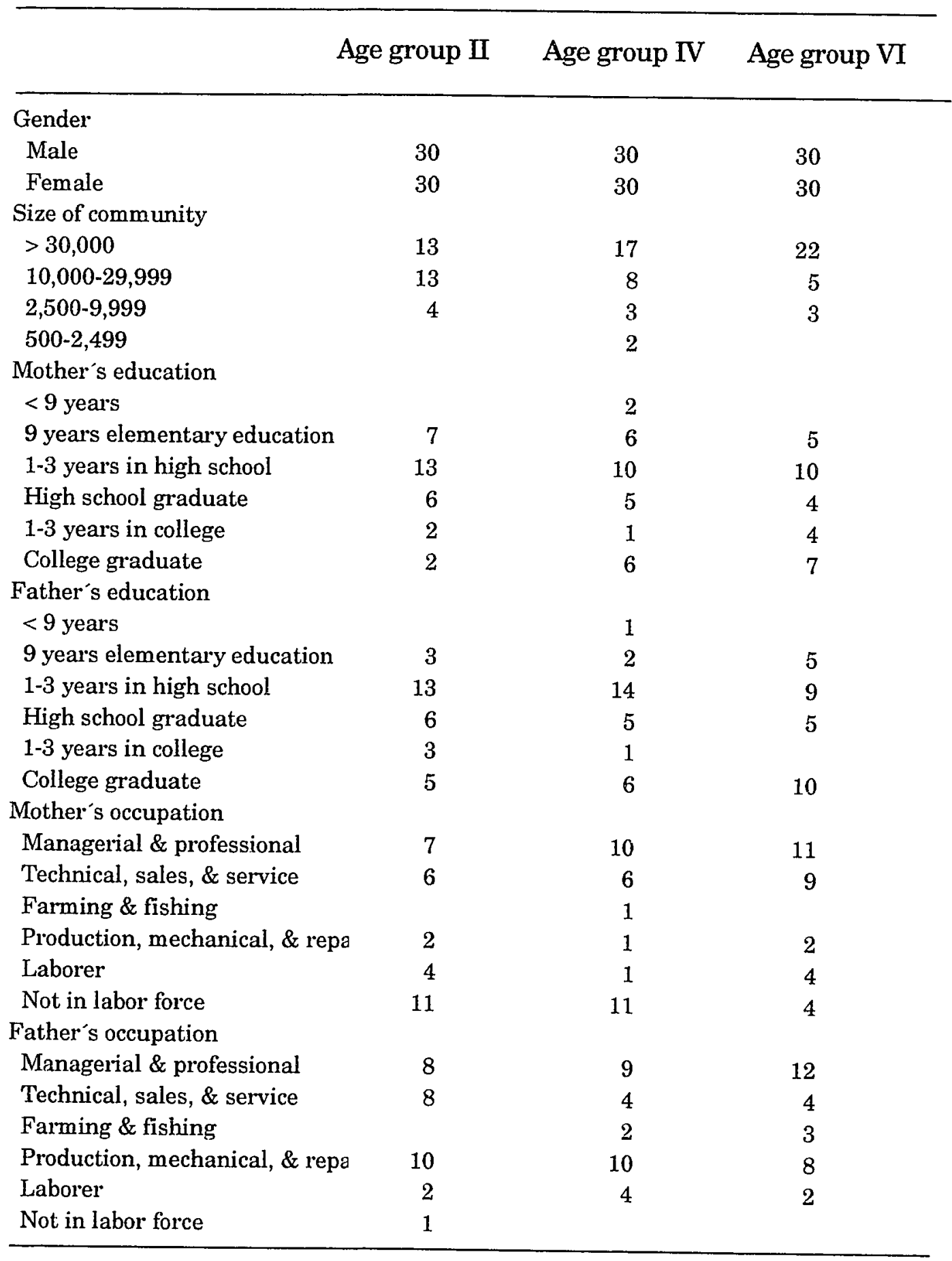


Table 4

Comparison of demographic characteristics of the MAP and the Ólafsson's study samples in Iceland. By percentages.

$$
\text { MAP study sample* Ólafsson study sample }{ }^{* * *}
$$

\begin{tabular}{lrr} 
Parents' occupation & & \\
Managerial \& professional & 38 & 14 \\
Technical, sales, \& service & 25 & 26 \\
Farming \& fishing & 4 & 6 \\
Production, mechanical, \& repair & 22 & 21 \\
Laborer & 11 & 33 \\
\hline
\end{tabular}

Note. $* \mathrm{~N}=150, * * \mathrm{~N}=832$.

The classification is based upon the occupation of employed persons only. 
Comparison of demographic characteristics of the Icelandic and the U.S. samples. By percentages.

Icelandic sample* U.S. sample ${ }^{* *}$

Mother's education

$<9$ years

9 years elementary education

$\begin{array}{rr}2 & 1 \\ 20 & 1 \\ 37 & 5 \\ 17 & 31 \\ 8 & 29 \\ 16 & 33\end{array}$

1-3 years in high school

1-3 years in college

Father's education

$<9$ years

9 years elementary education

$1 \quad 1$

1-3 years in high school

High school graduate

1-3 years in college

18

College graduate

Mother's occupation

Managerial \& professional

$\begin{array}{rr}31 & 33 \\ 24 & 38 \\ 1 & 1 \\ 6 & 5 \\ 10 & 1 \\ 29 & 22\end{array}$

Not in labor force

Father's occupation

Managerial \& professional

$33 \quad 53$

Technical, sales, \& service

18

14

Farming \& fishing

$6 \quad 1$

Production, mechanical, \& repair

$32 \quad 25$

Laborer

10

6

Not in labor force

11

Note. $* \mathrm{~N}=177, * * \mathrm{~N}=1204$. 
the two samples. It would seem to appear that the parents in the U.S. standardization sample are of somewhat higher socioeconomic status than the parents of the Icelandic children that participated in this study.

\section{Research Findings}

In this study, less range was obtained on several of the subtest scores than within the U.S. standardization sample. Hence, the Icelandic children obtained less of the very low scores, but also did not obtain as many of the highest scores possible. This affects the conclusion of the study, as the main focus was on the distribution among the lower scores. Figures 1 to 27 present the performance of the two samples on each of the 27 subtests in percentages, and allow for a comparison and inspection of differences. The order of the subtests is the same as presented in the MAP manual. Figures A-28 to A-33 in Appendix display the percentile rank order for the Icelandic sample on each of the 27 subtests. These figures can be compared to figures A-34 to A-39 that display the performance of the same three age groups within the U.S. standardization sample. The data reveal that there are minimal differences between the performances of the two samples on several of the subtests, but noticeable differences on others. On some of the subtests, the U.S. children tend to perform better, while the Icelandic children perform better on others. Furthermore, on 
Figure 1. Tower.

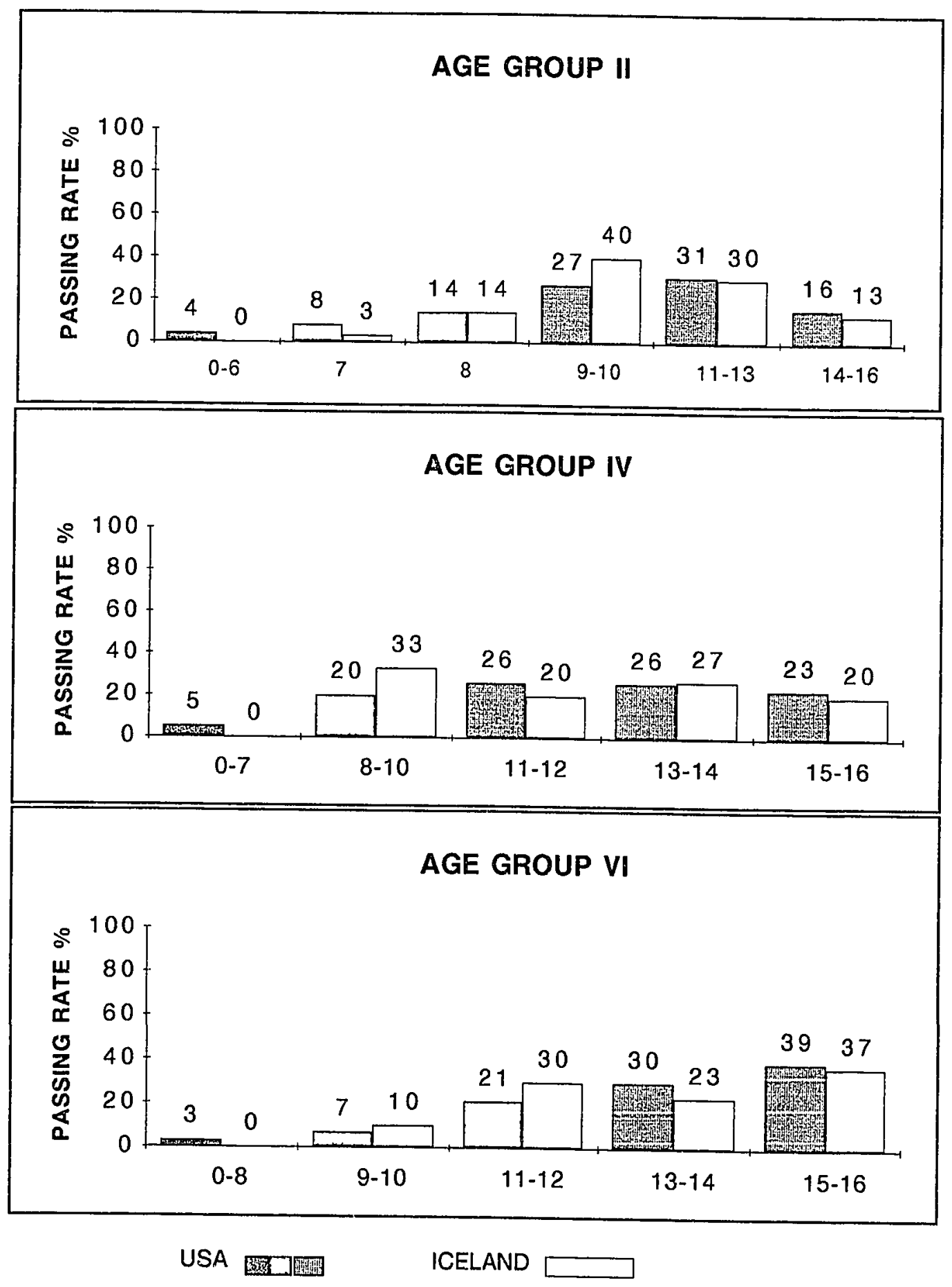

Note. The numbers below the bar graphs indicate subtest raw scores. 
Figure 2. Sequencing.

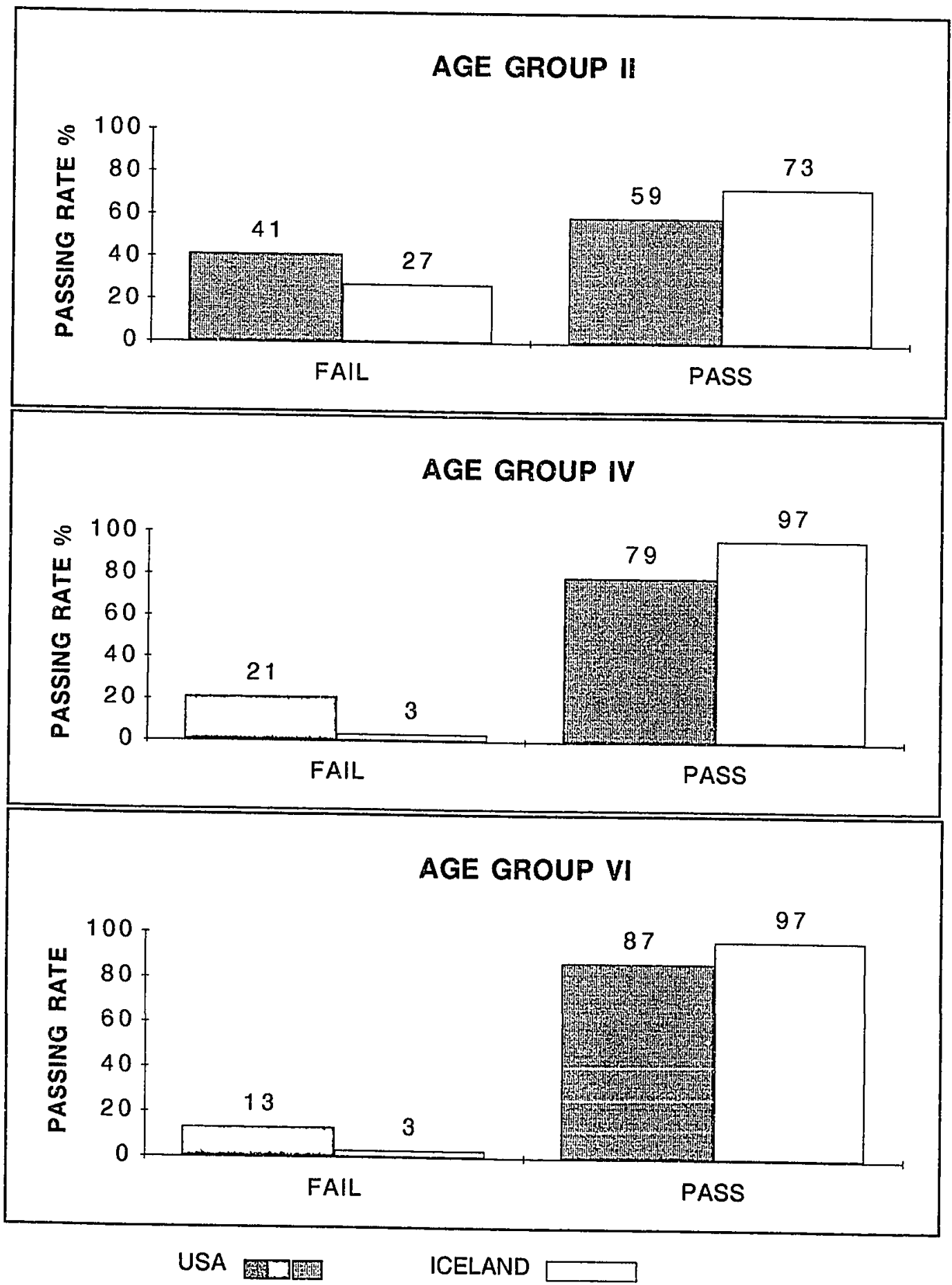

Note. The text below the bar graphs indicates subtest raw scores. 
Figure 3. Block Designs.
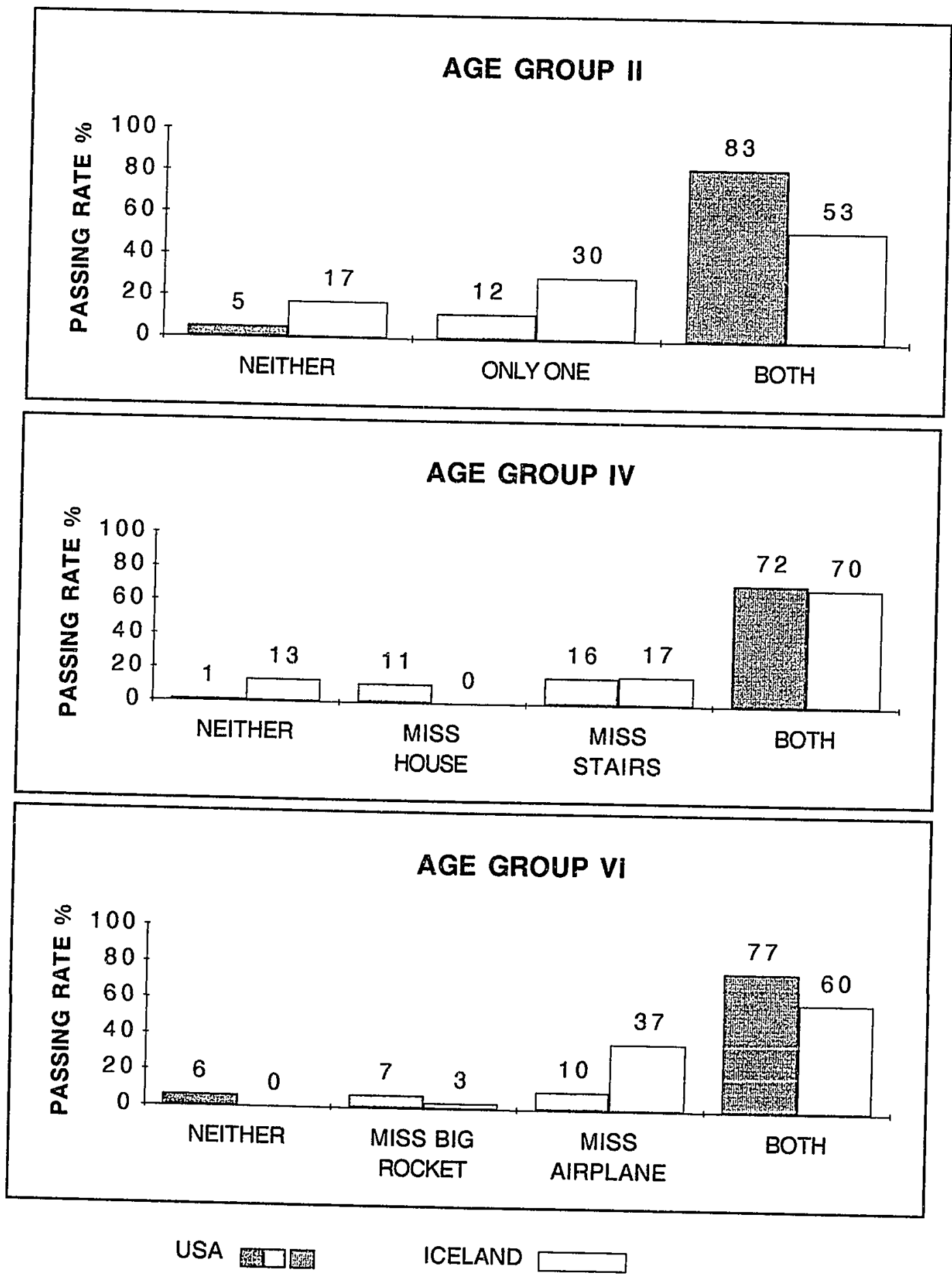

Note. The text below the bar graphs indicates subtest raw scores. 
Figure 4. Block Tapping.

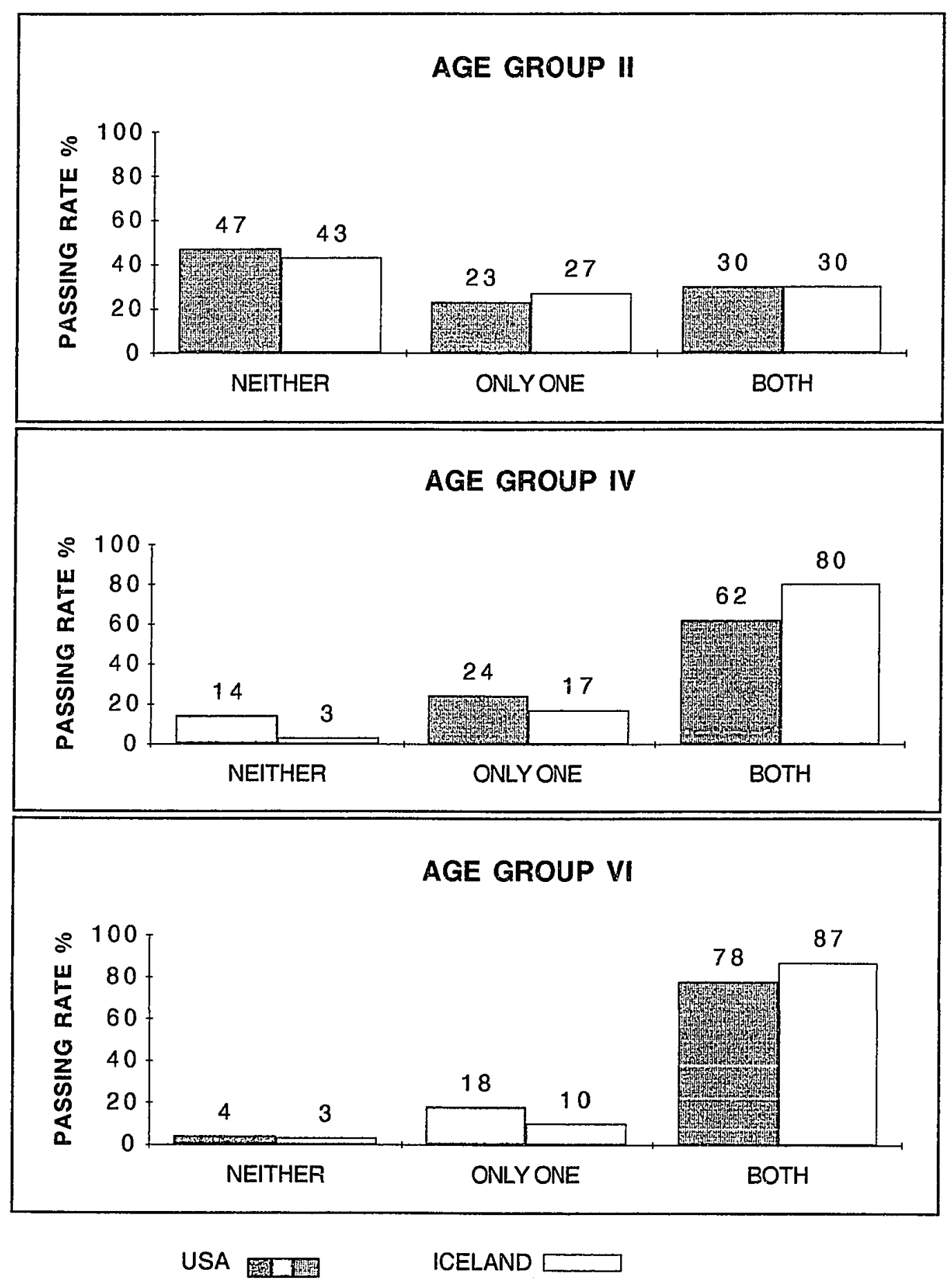

Note. The text below the bar graphs indicates subtest raw scores. 
Figure 5. Stereognosis.
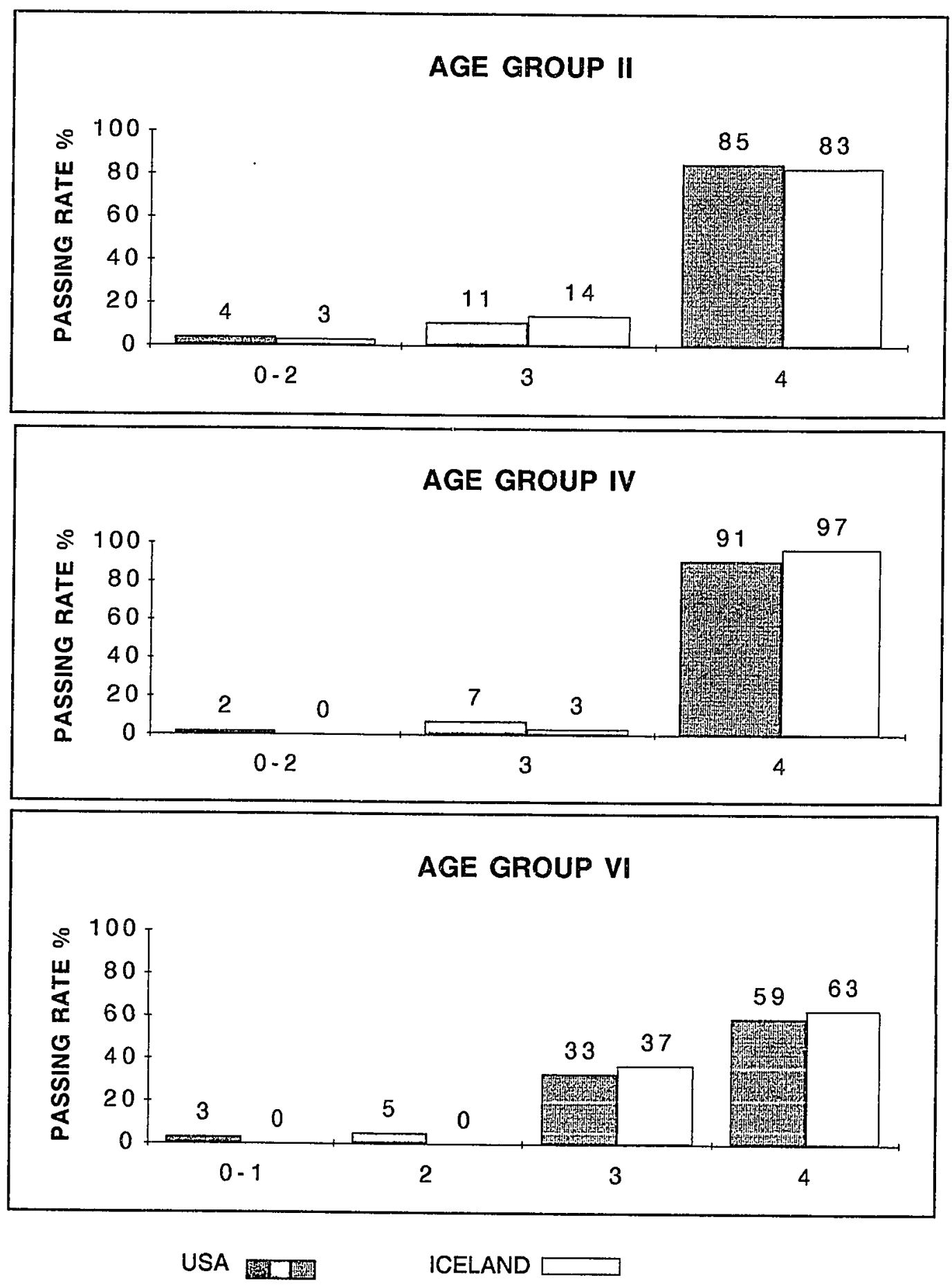

Note. The numbers below the bar graphs indicate subtest raw scores. 
Figure 6. Finger Localization.

\section{AGE GROUP ॥}
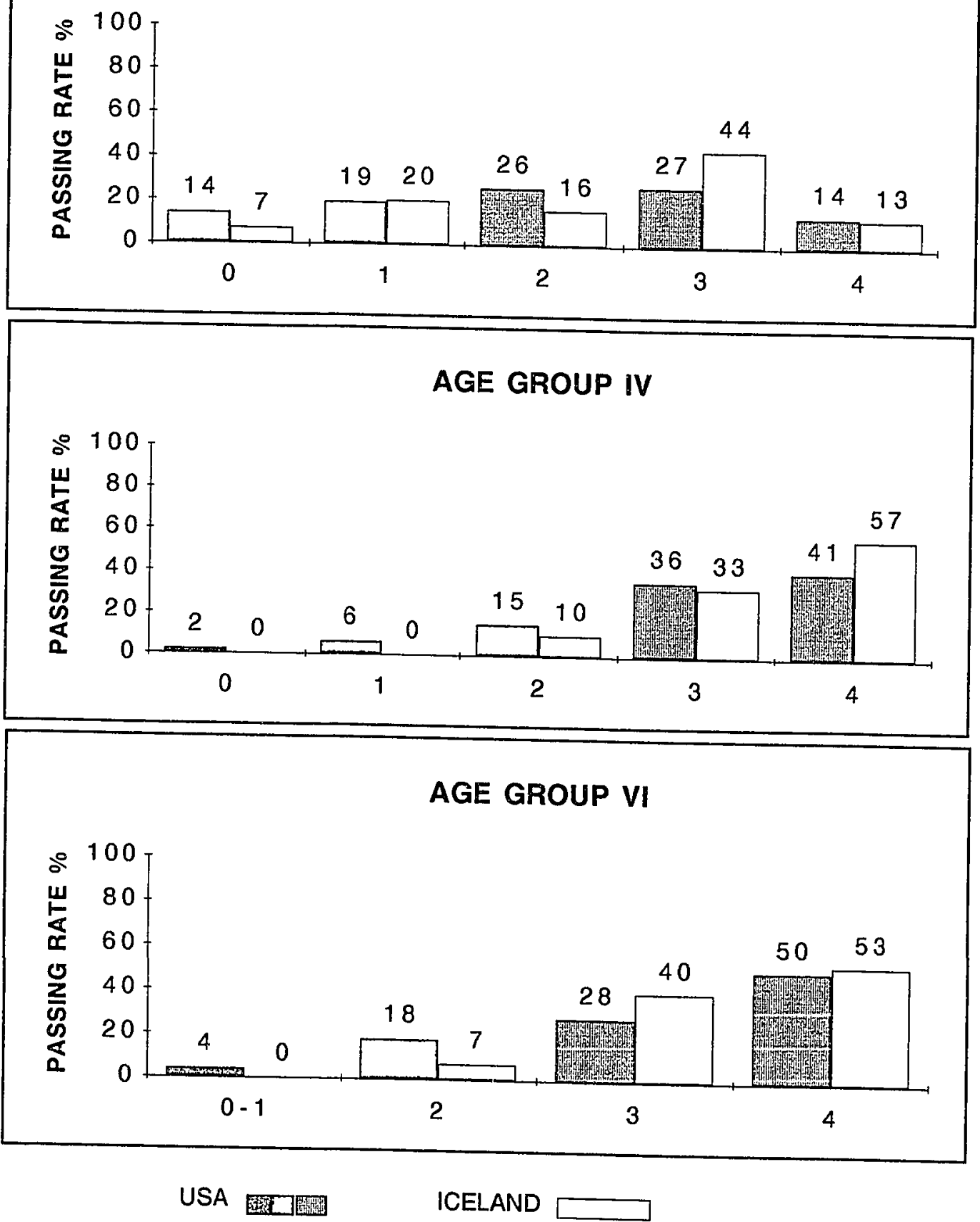

Note. The numbers below the bar graphs indicate subtest raw scores. 
Figure 7. Object Memory.
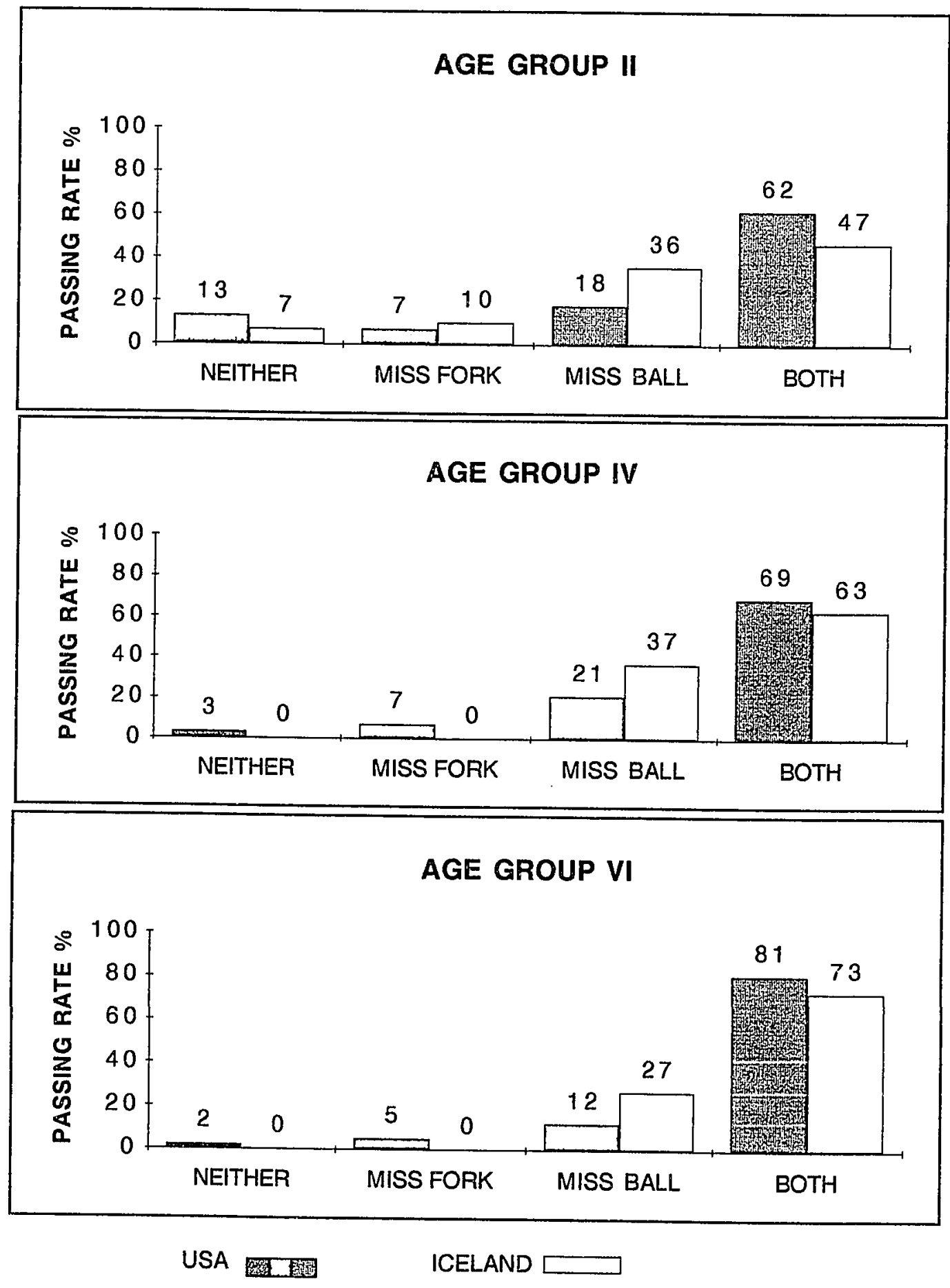

Note. The text below the bar graphs indicates subtest raw scores. 
Figure 8. Puzzles.
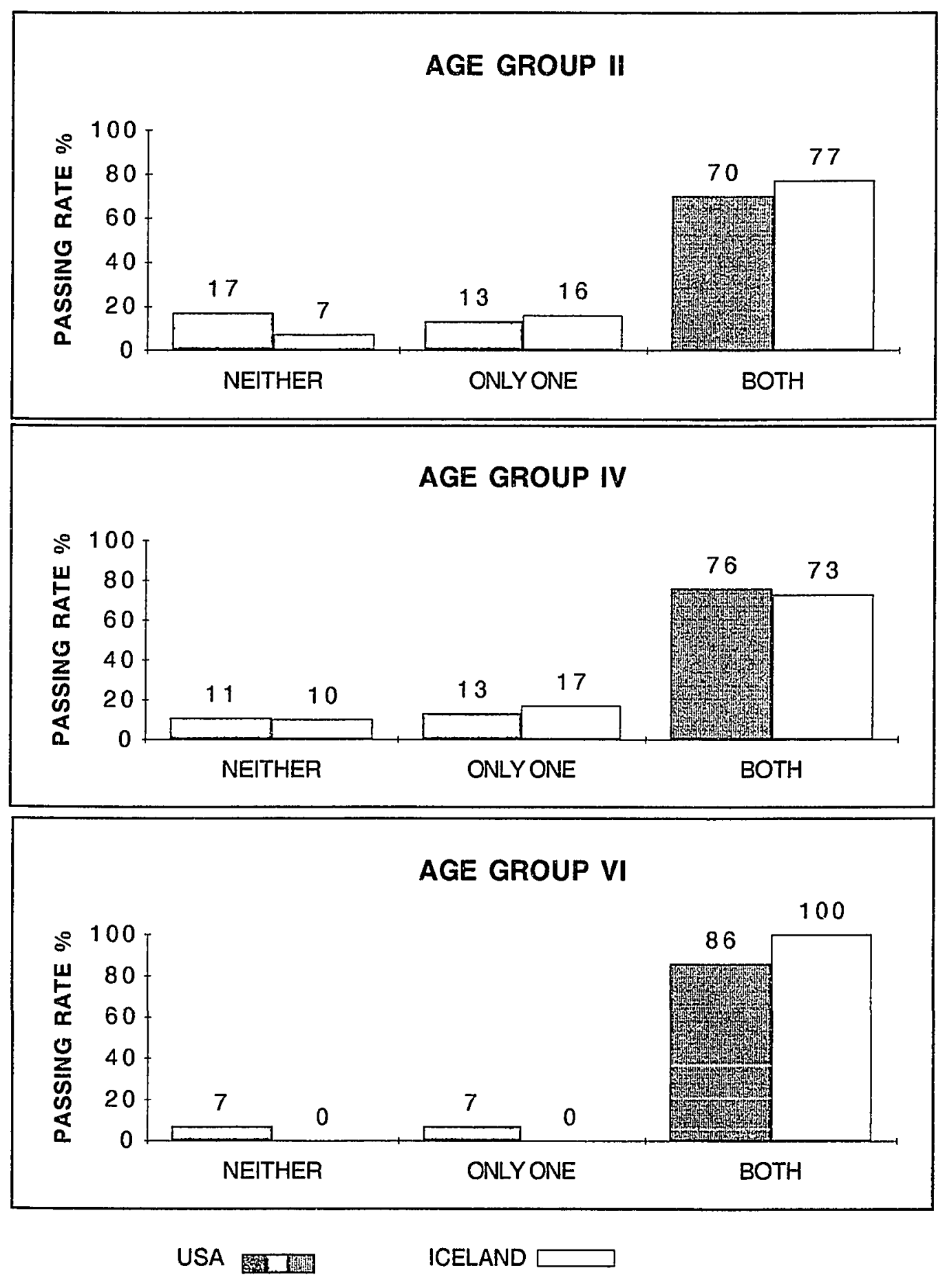

Note. The text below the bar graphs indicates subtest raw scores. 
Figure 9. Figure-Ground.

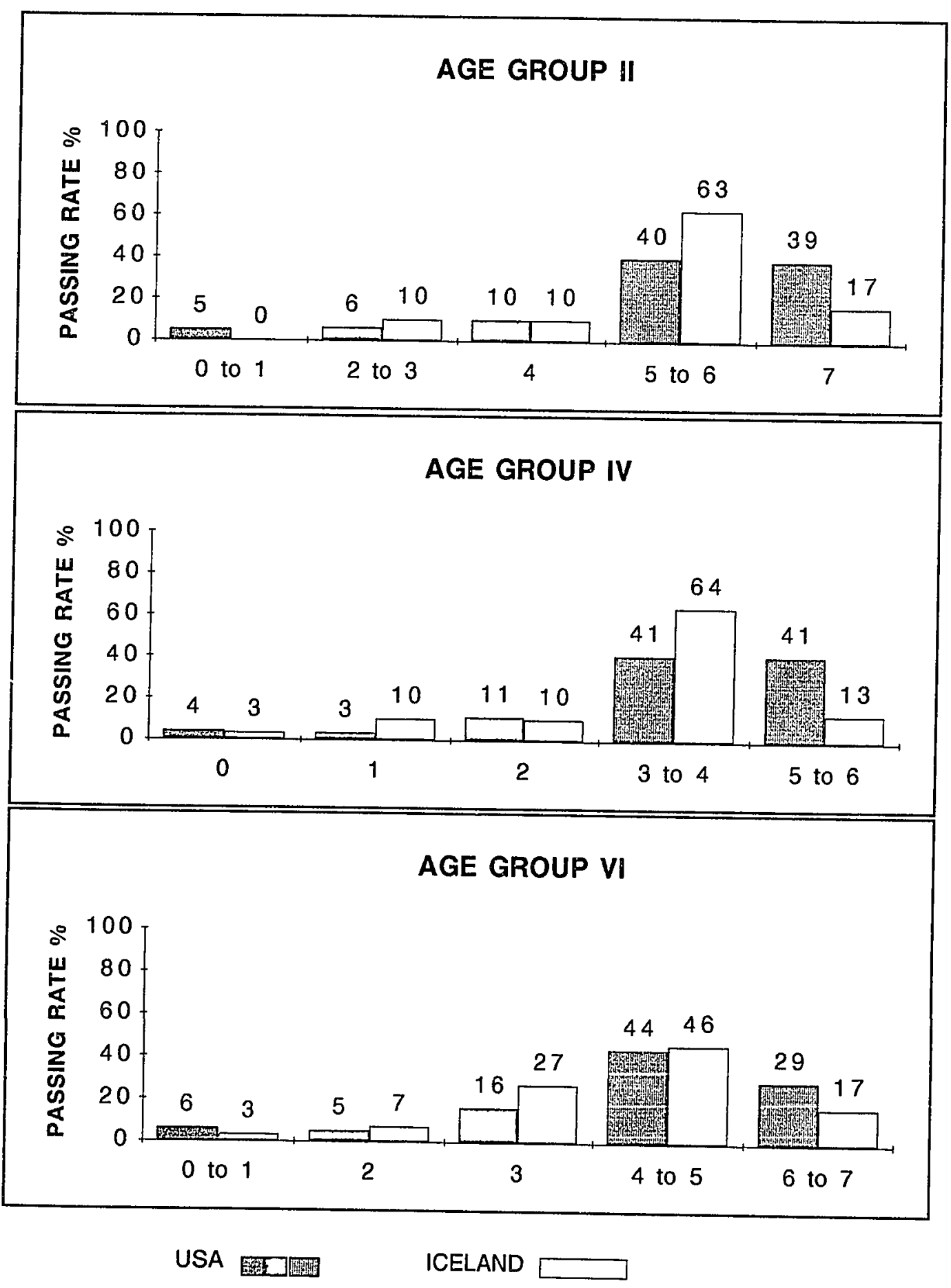

Note. The numbers below the bar graphs indicate subtest raw scores. 
Figure 10. Draw-a-Person.
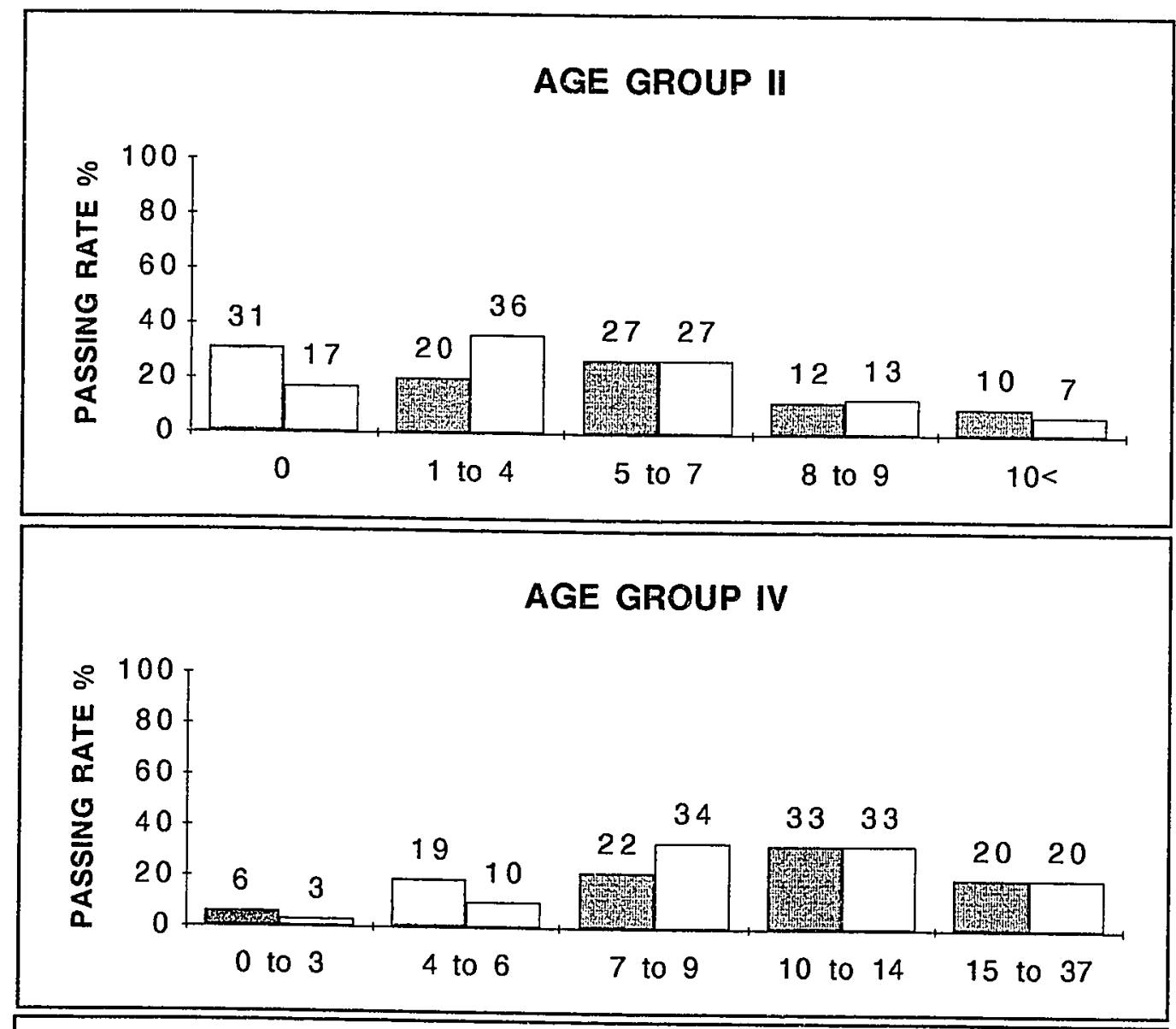

AGE GROUP VI

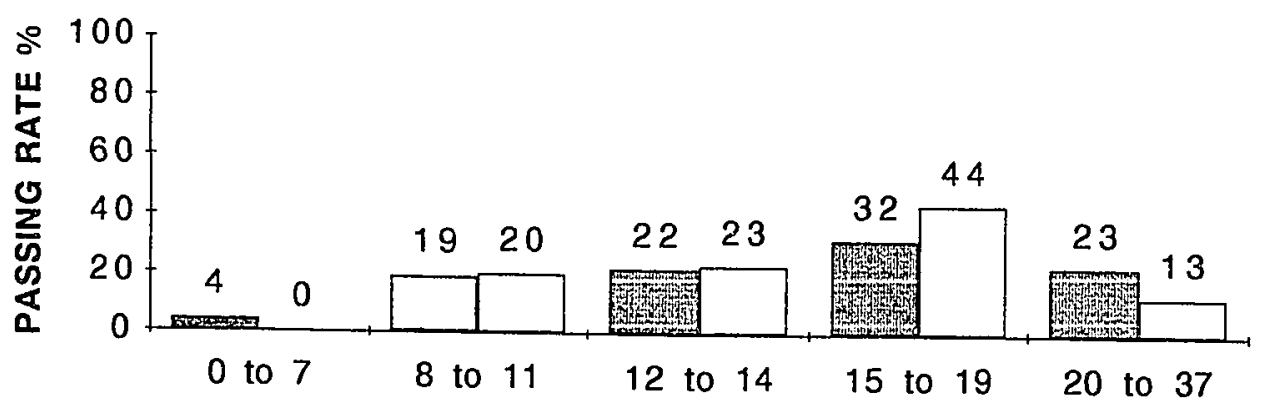

USA 囦通]国啳

ICELAND $\square$

Note. The numbers below the bar graphs indicate subtest raw scores. 
Figure 11. Motor Accuracy.

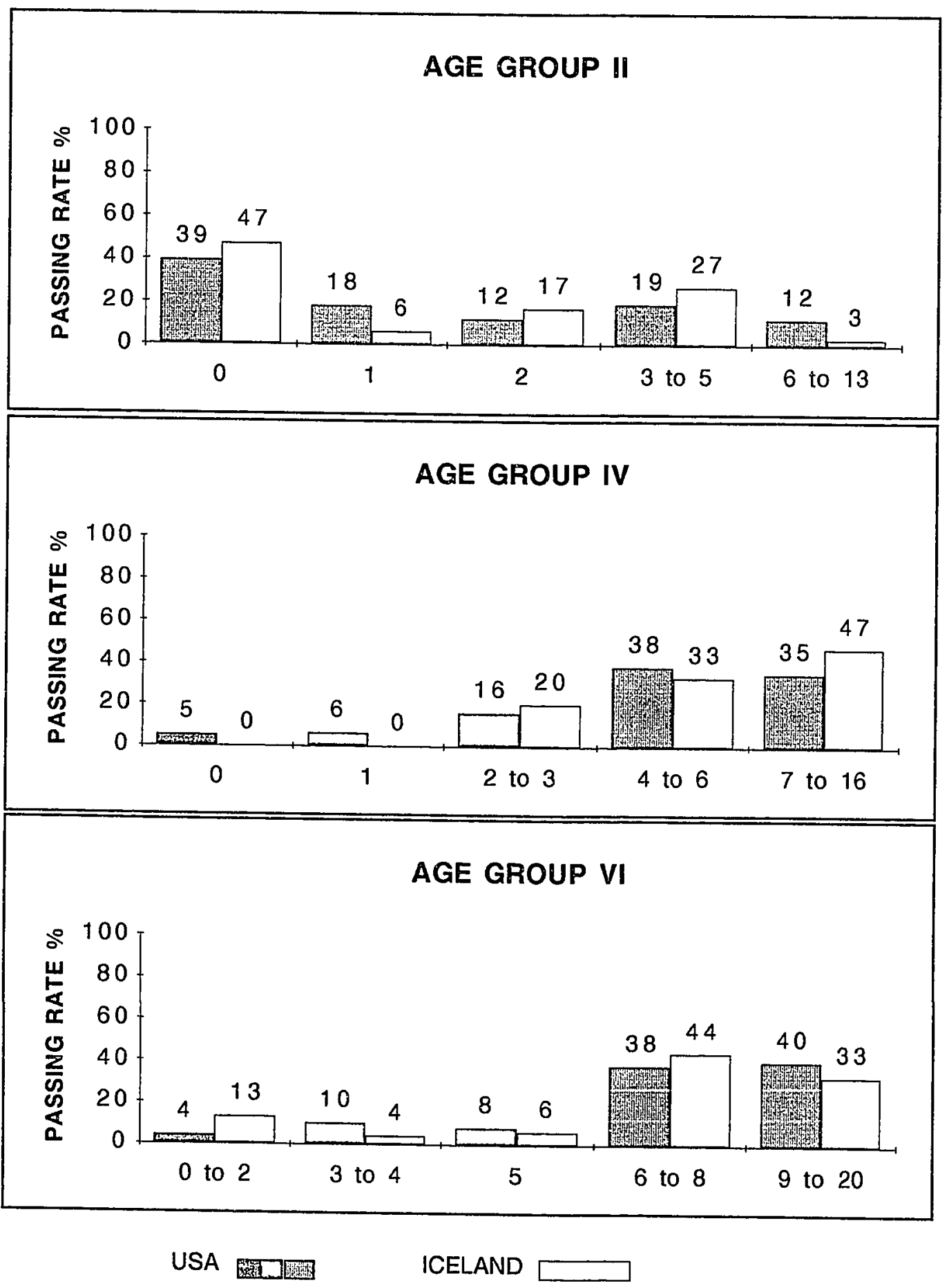

Note. The numbers below the bar graphs indicate subtest raw scores. 

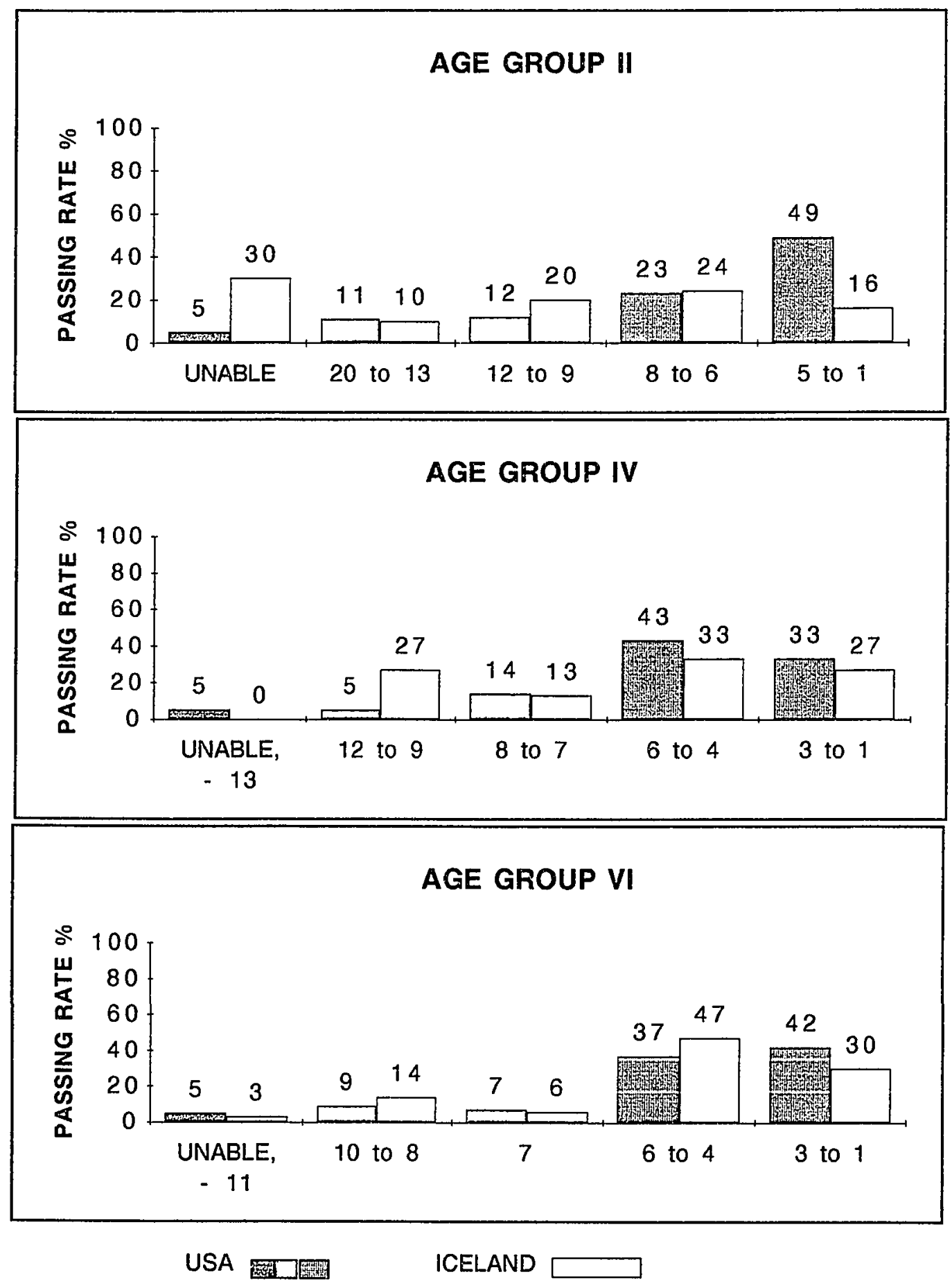

Note. The numbers below the bar graphs indicate subtest raw scores. 
Figure 13. Hand-to-Nose.

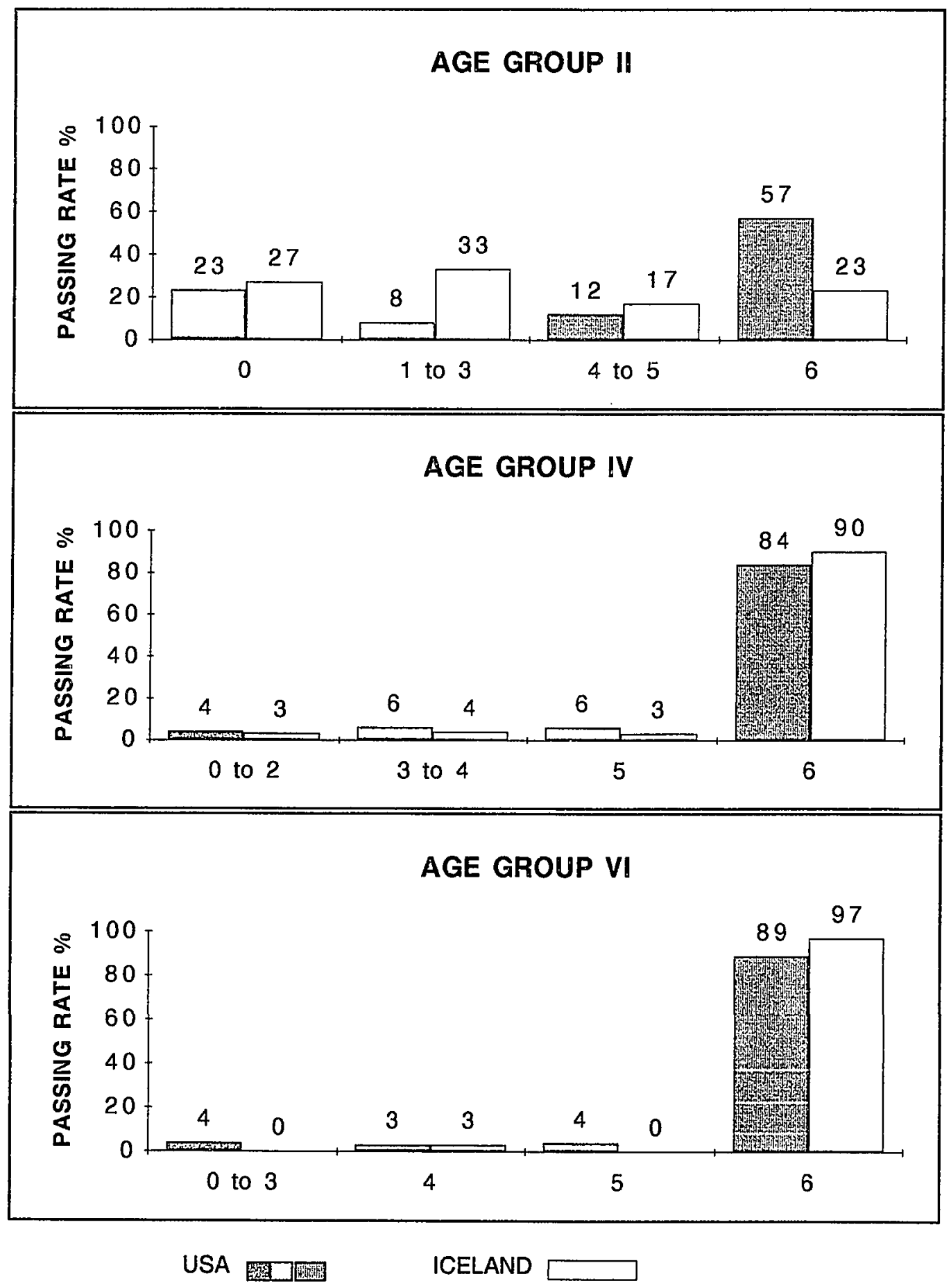

Note. The numbers below the bar graphs indicate subtest raw scores. 
Figure 14. Romberg.

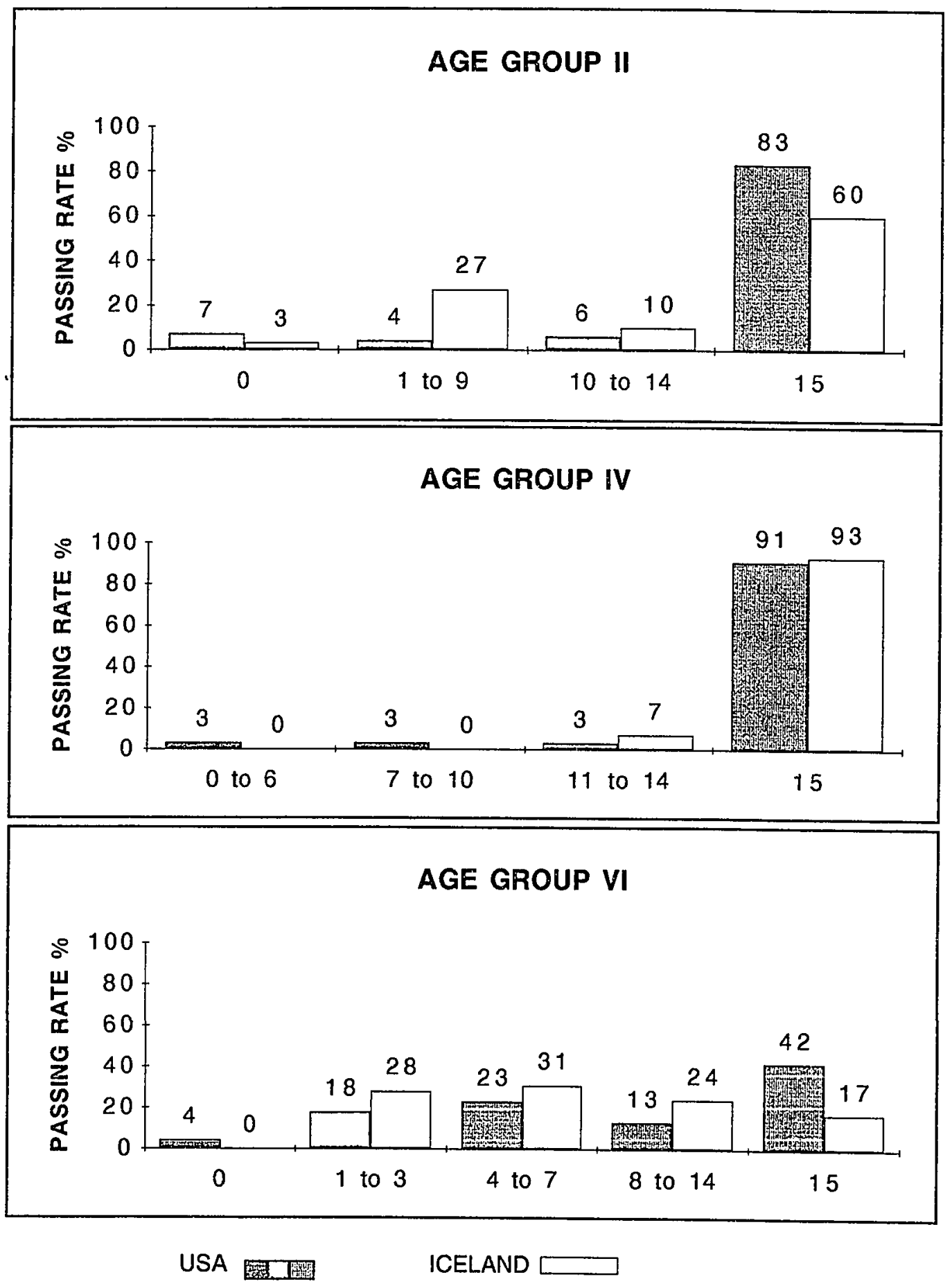

Note. The numbers below the bar graphs indicate subtest raw scores. 
Figure 15. Stepping.

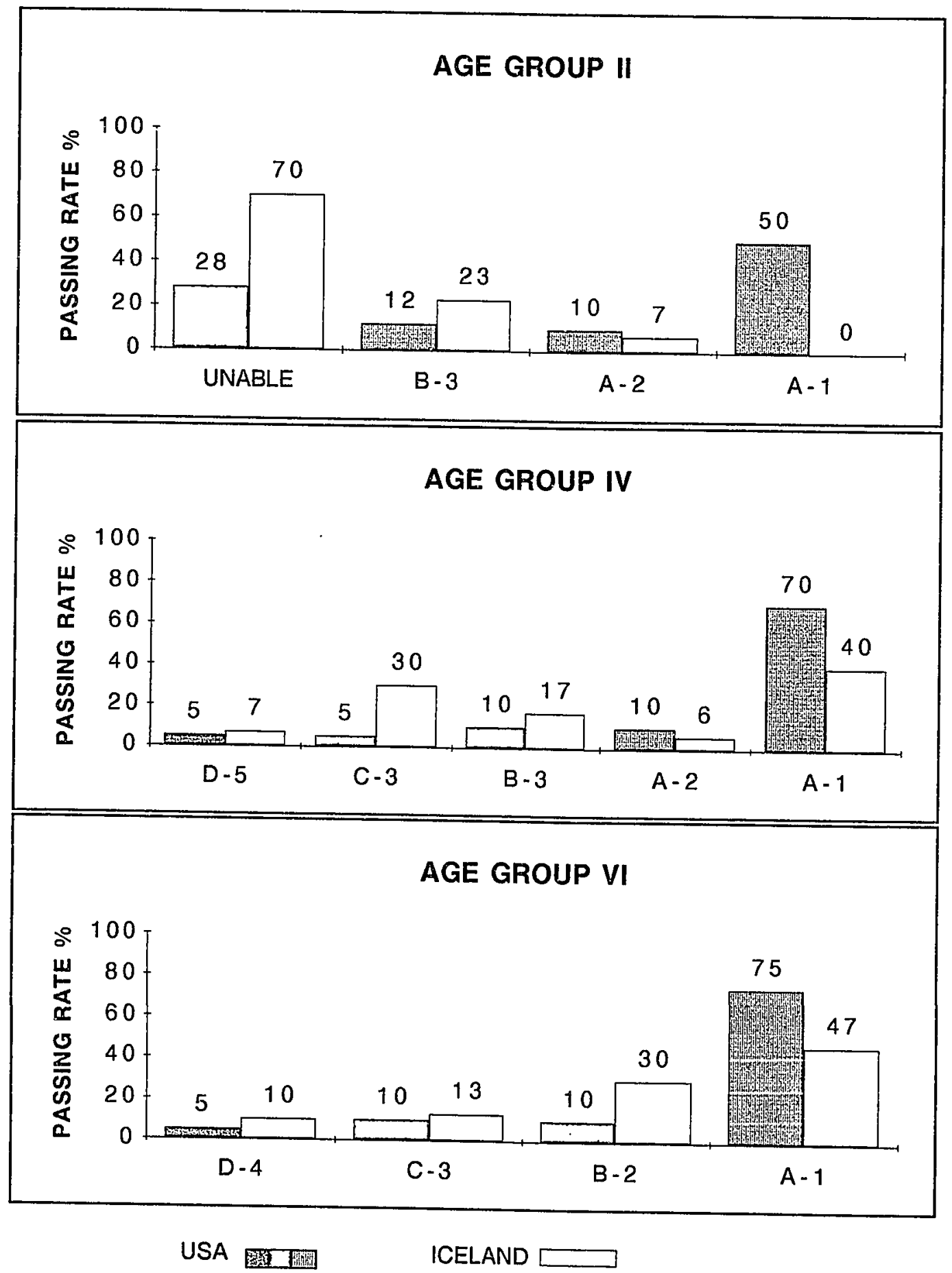

Note. The text below the bar graphs indicates subtest raw scores. 
Figure 16. Walks Line.

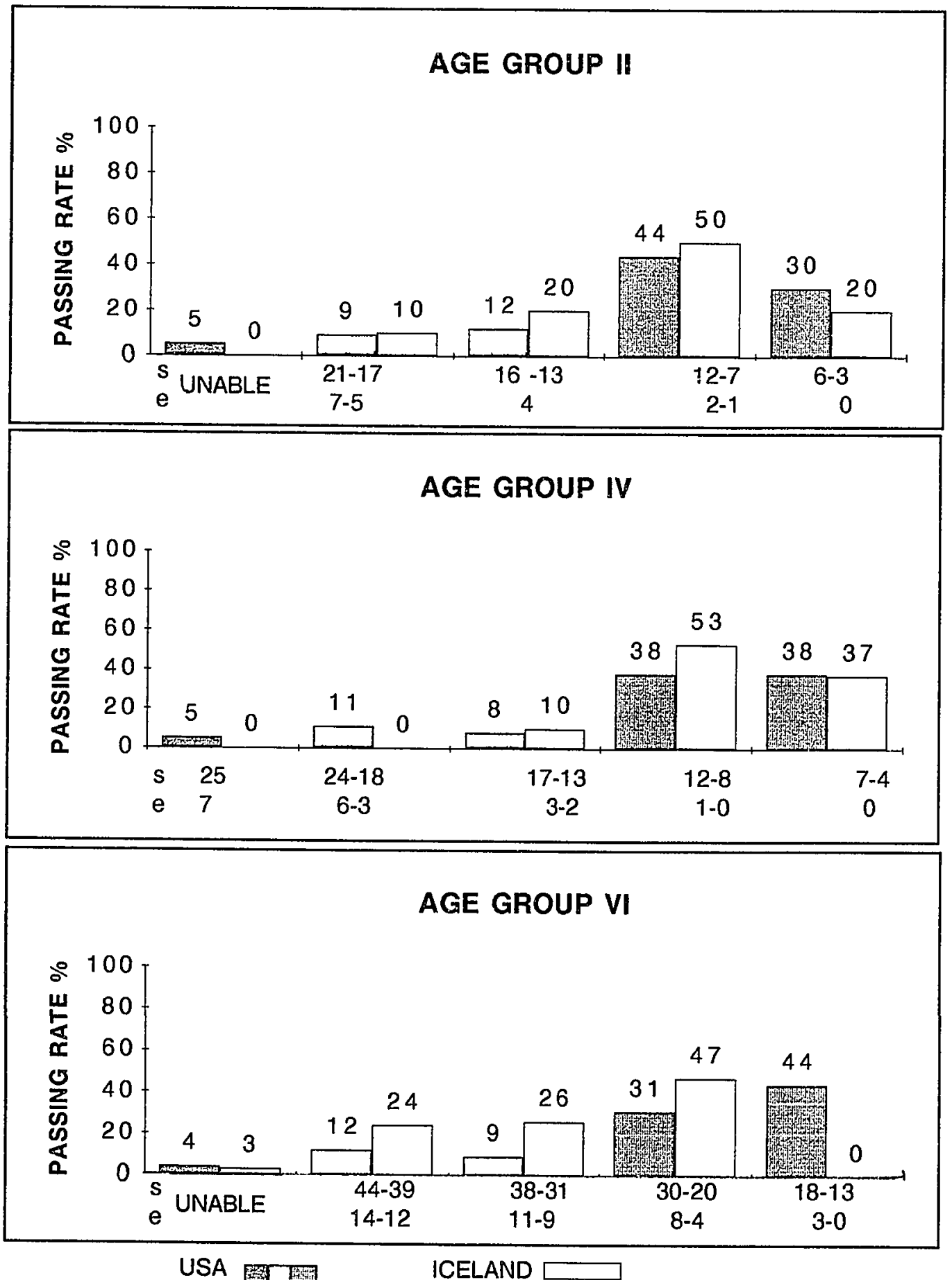

Note. The numbers below the bar graphs indicate subtest raw scores. 
Figure 17. Supine Flexion.

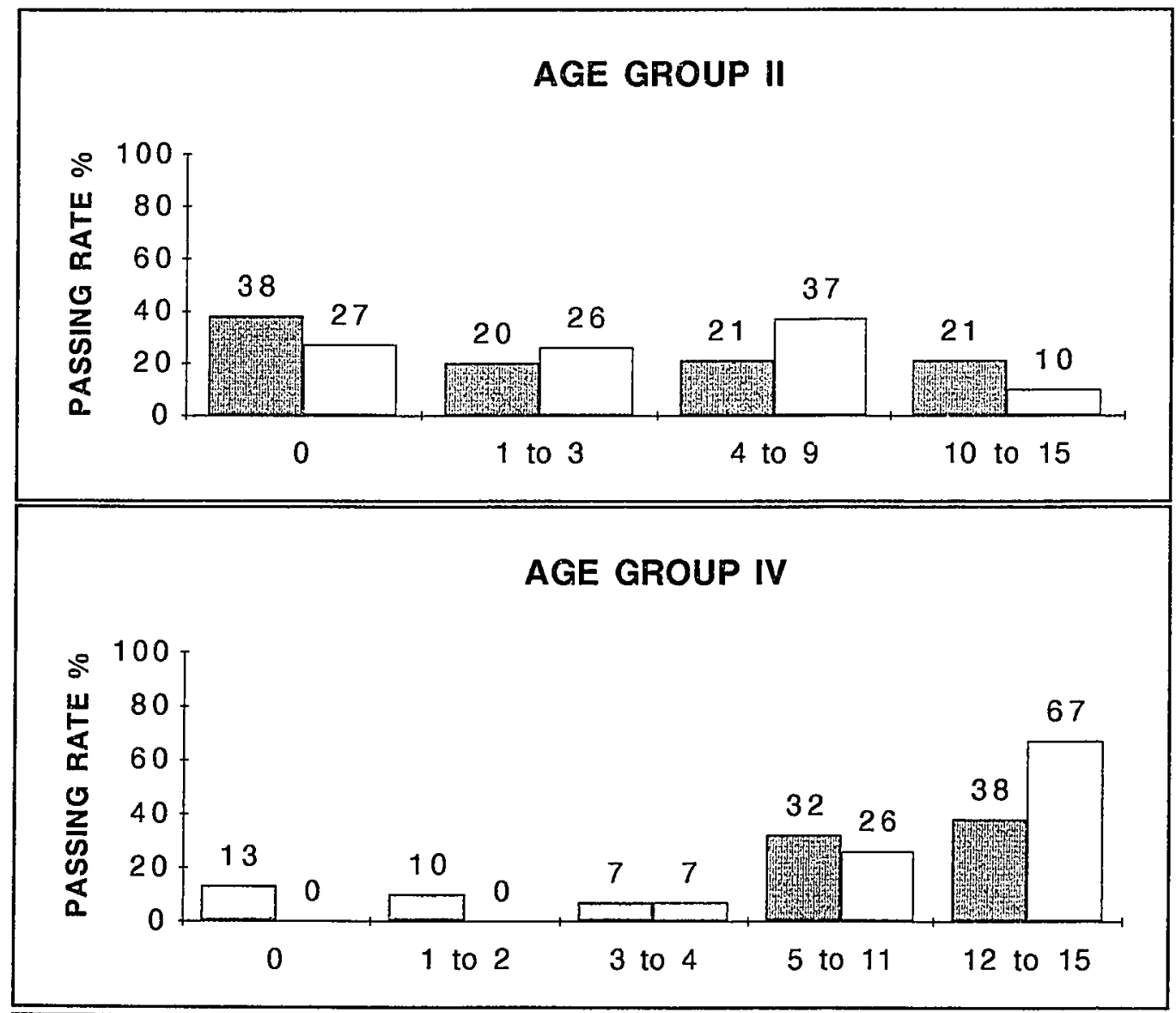

AGE GROUP VI

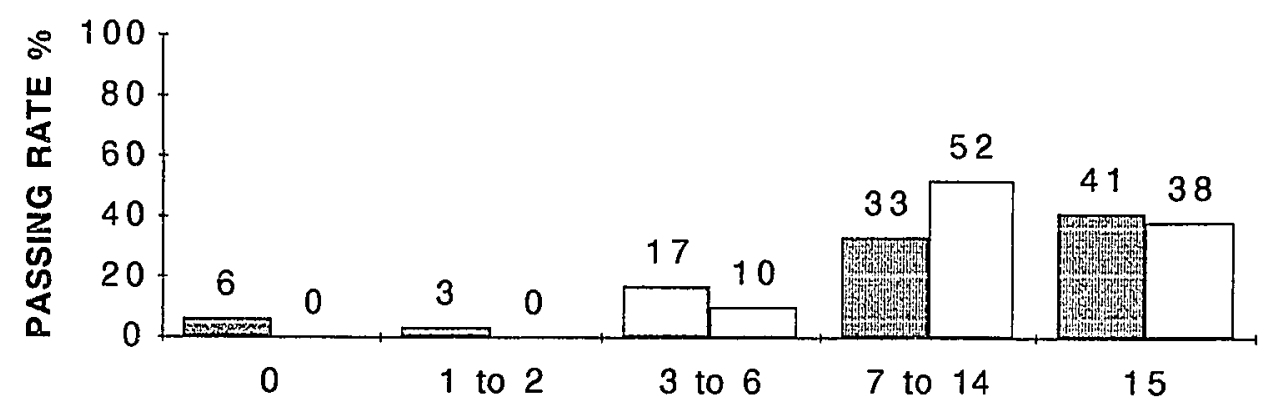

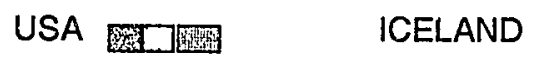

Note. The numbers below the bar graphs indicate subtest raw scores. 
Figure 18. Kneel-Stand.
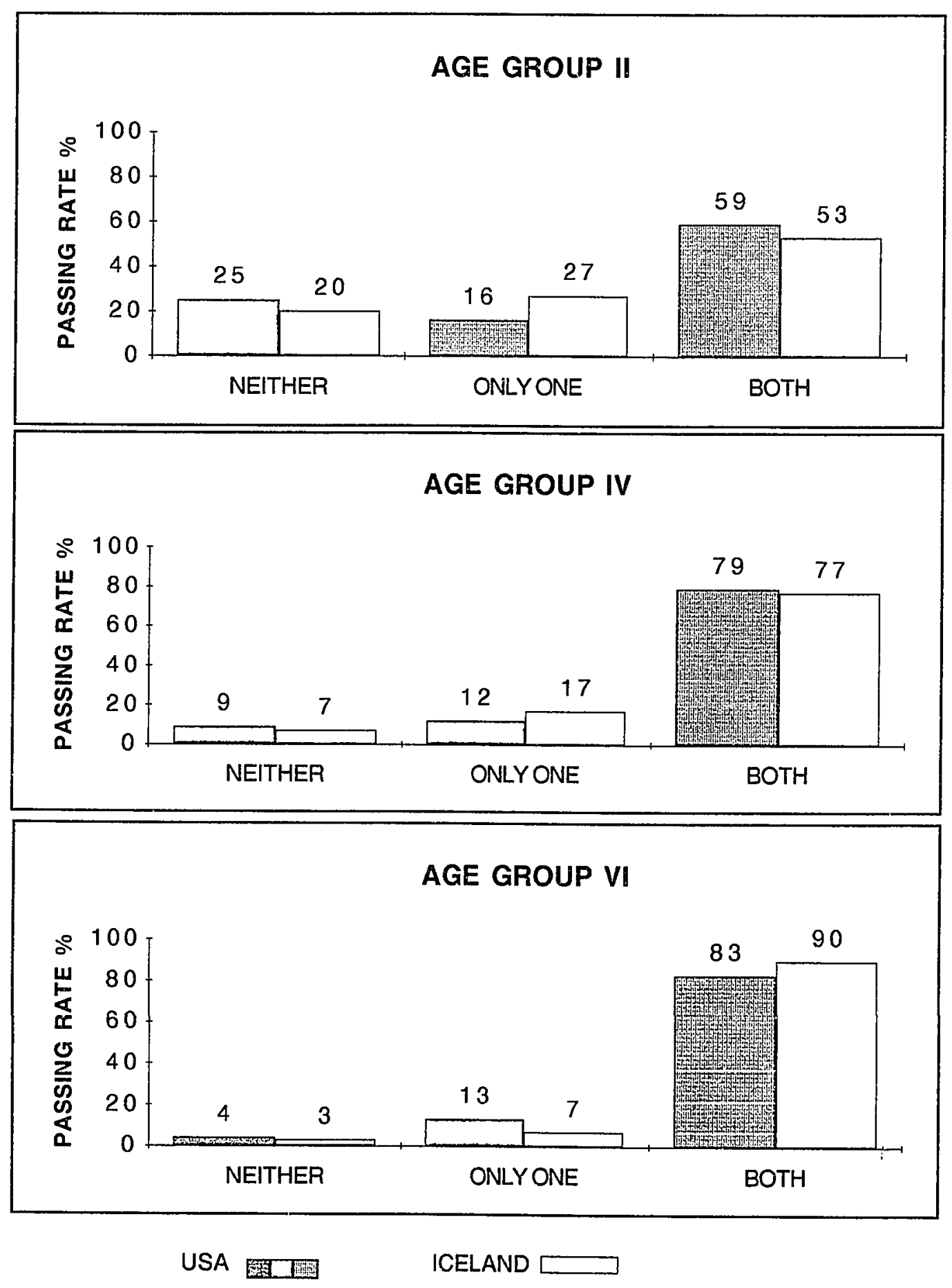

Note. The text below the bar graphs indicates subtest raw scores. 
Figure 19. Imitation of Postures.

\section{AGE GROUP |}

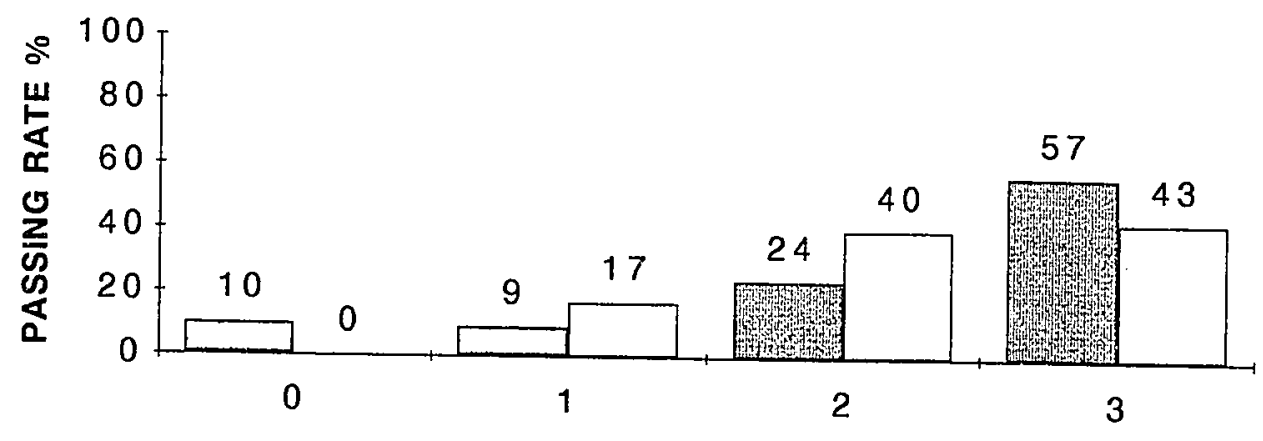

\section{AGE GROUP IV}

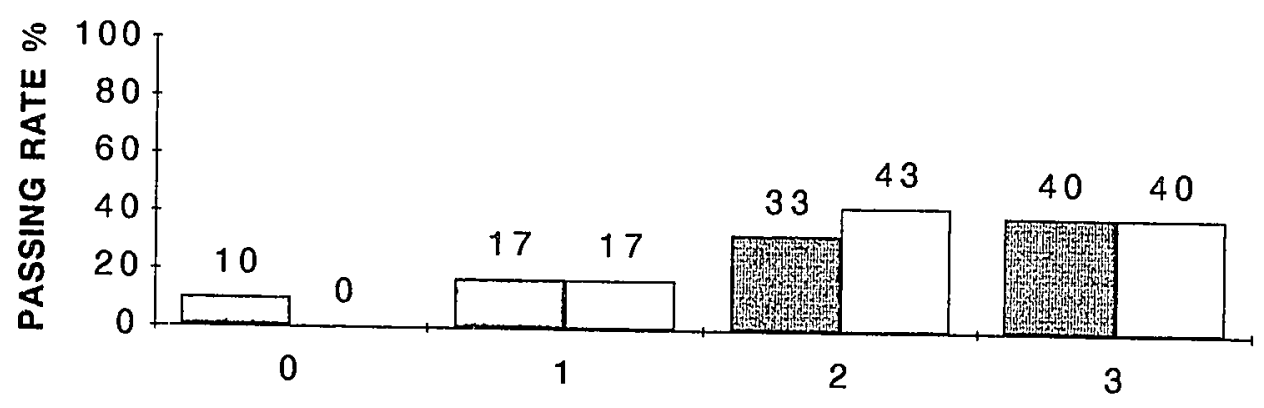

\section{AGE GROUP VI}

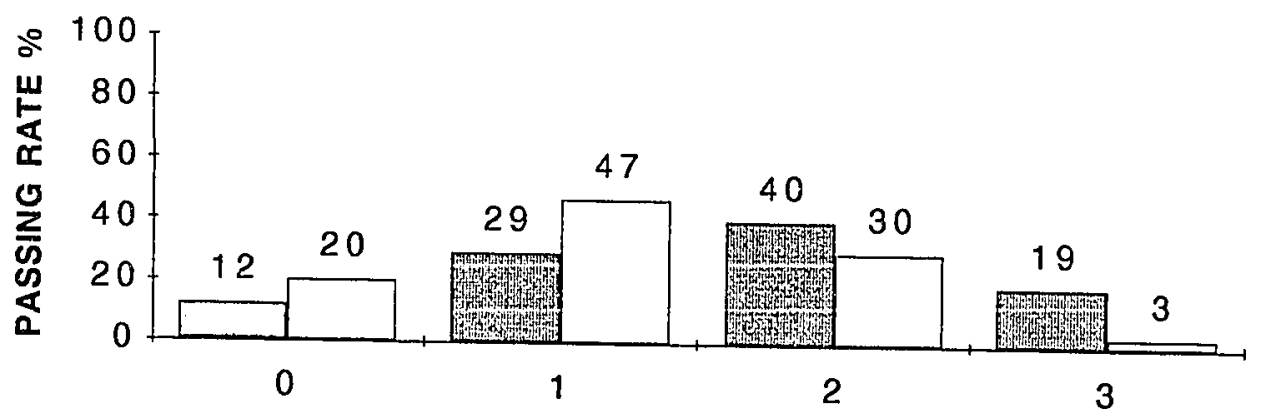

USA ICELAND

Note. The numbers below the bar graphs indicate subtest raw scores. 
Figure 20. Tongue Movements.
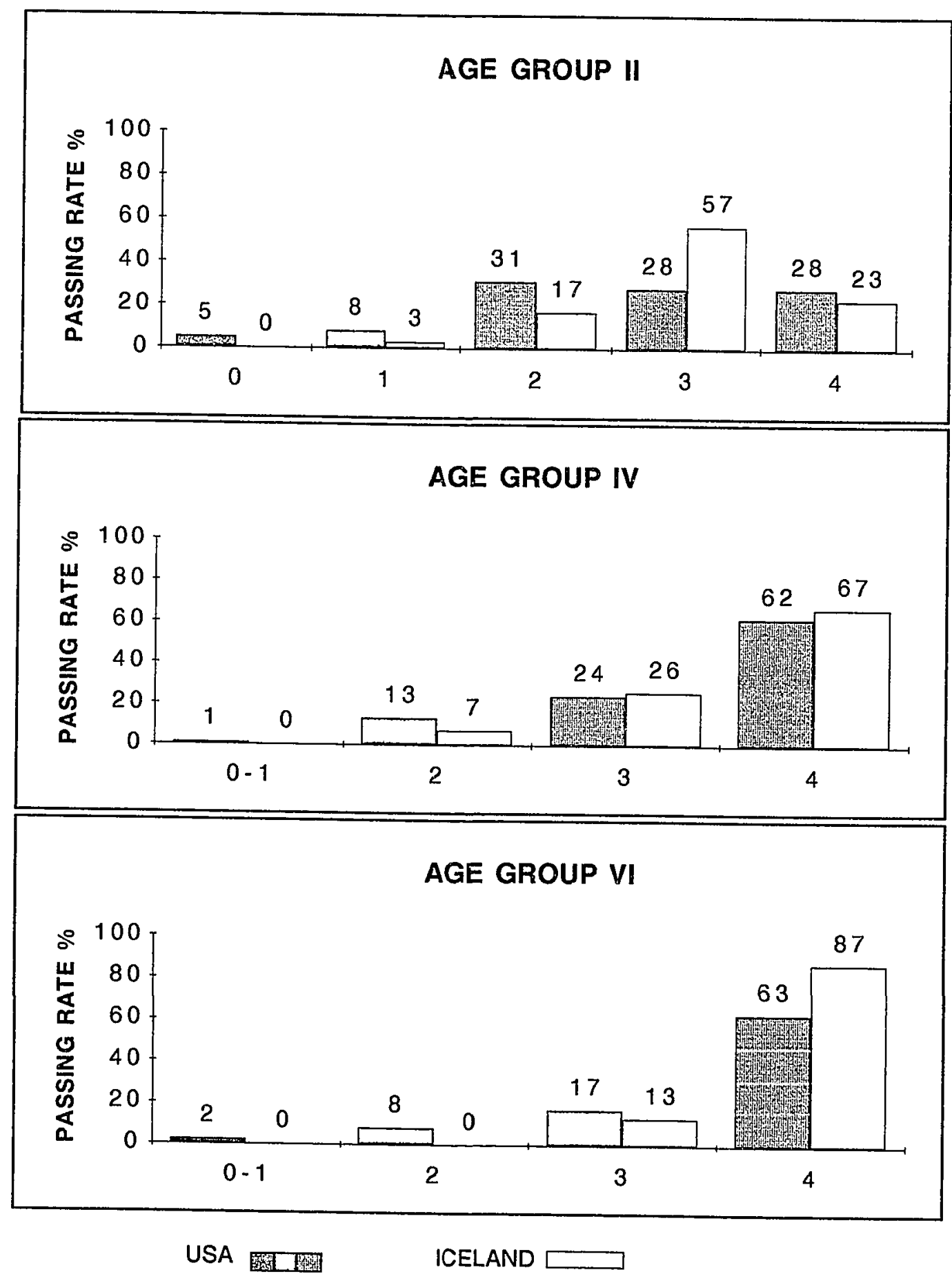

Note. The numbers below the bar graphs indicate subtest raw scores. 
Figure 21. Rapid Alternating Movements.

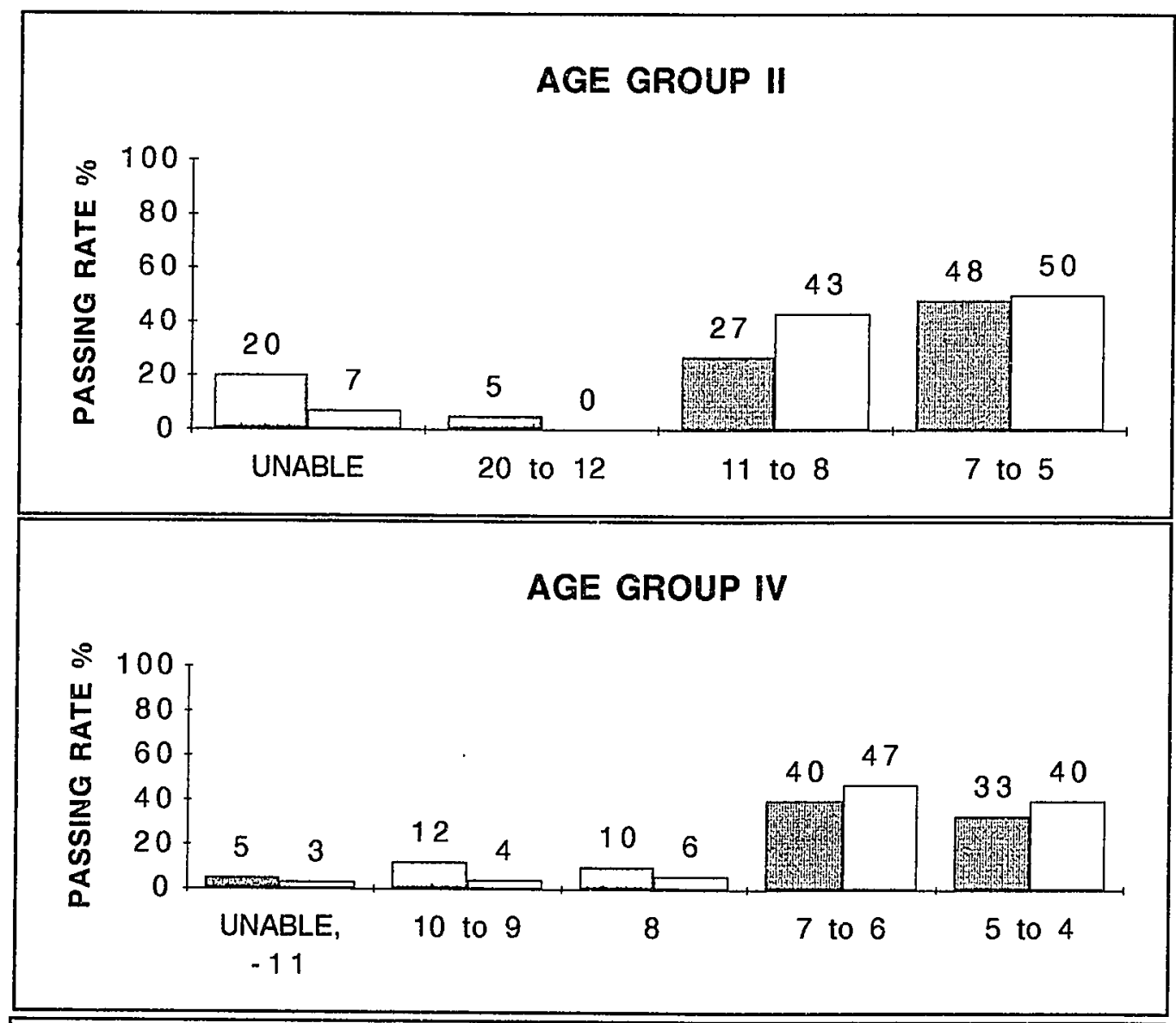

\section{AGE GROUP VI}

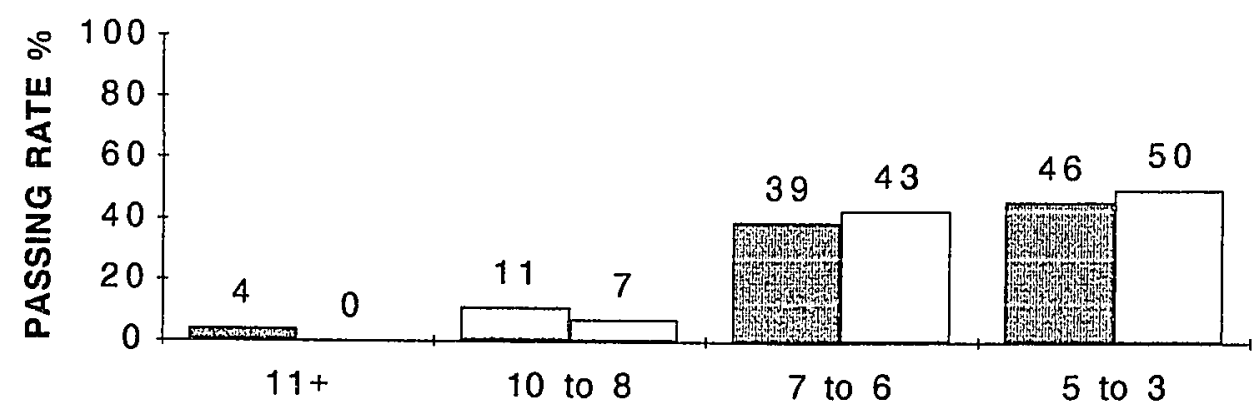

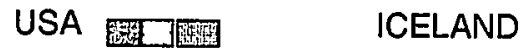

Note. The numbers below the bar graphs indicate subtest raw scores. 
Figure 22. Maze.

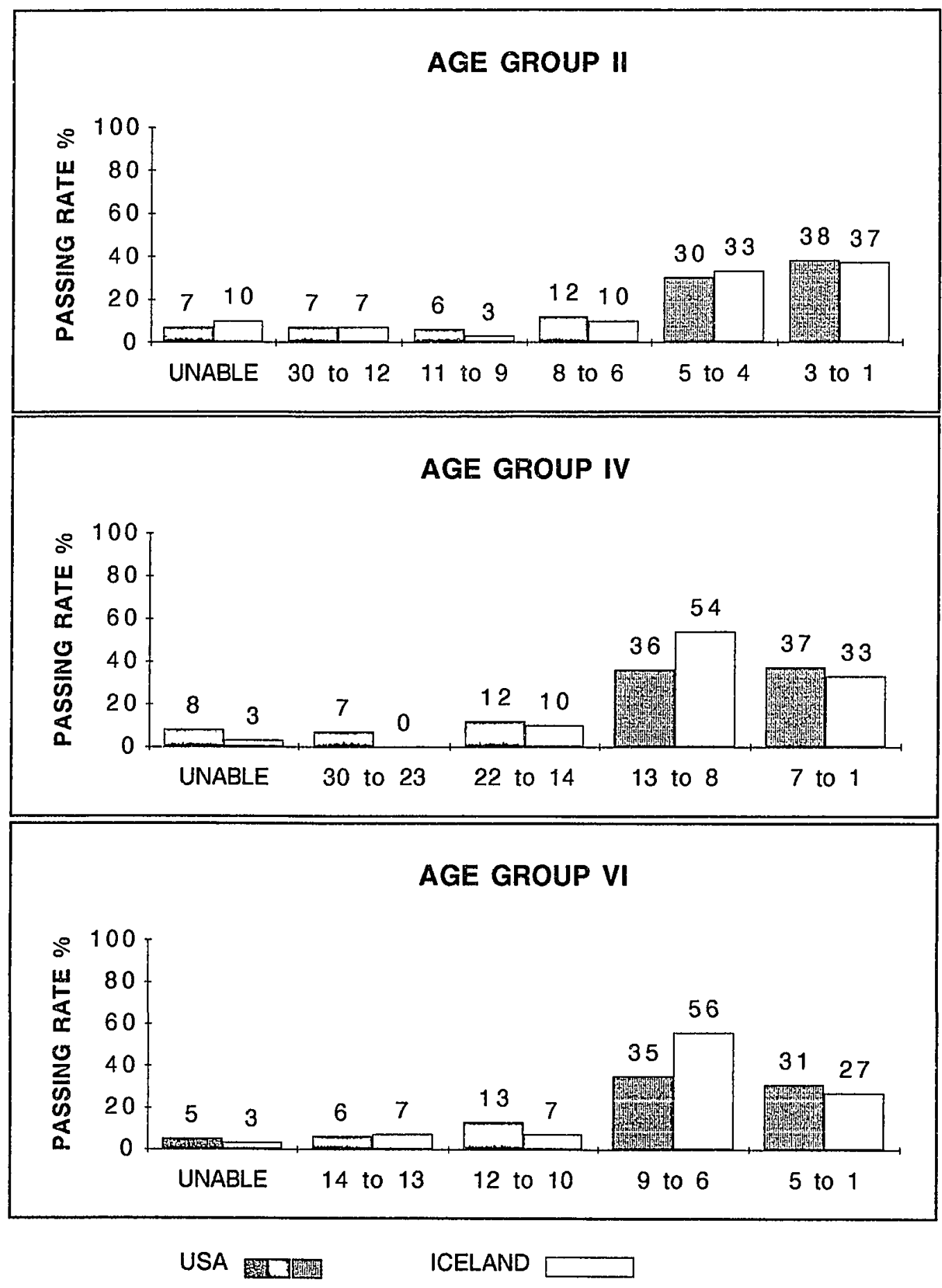

Note. The numbers below the bar graphs indicate subtest raw scores. 
Figure 23. General Information.
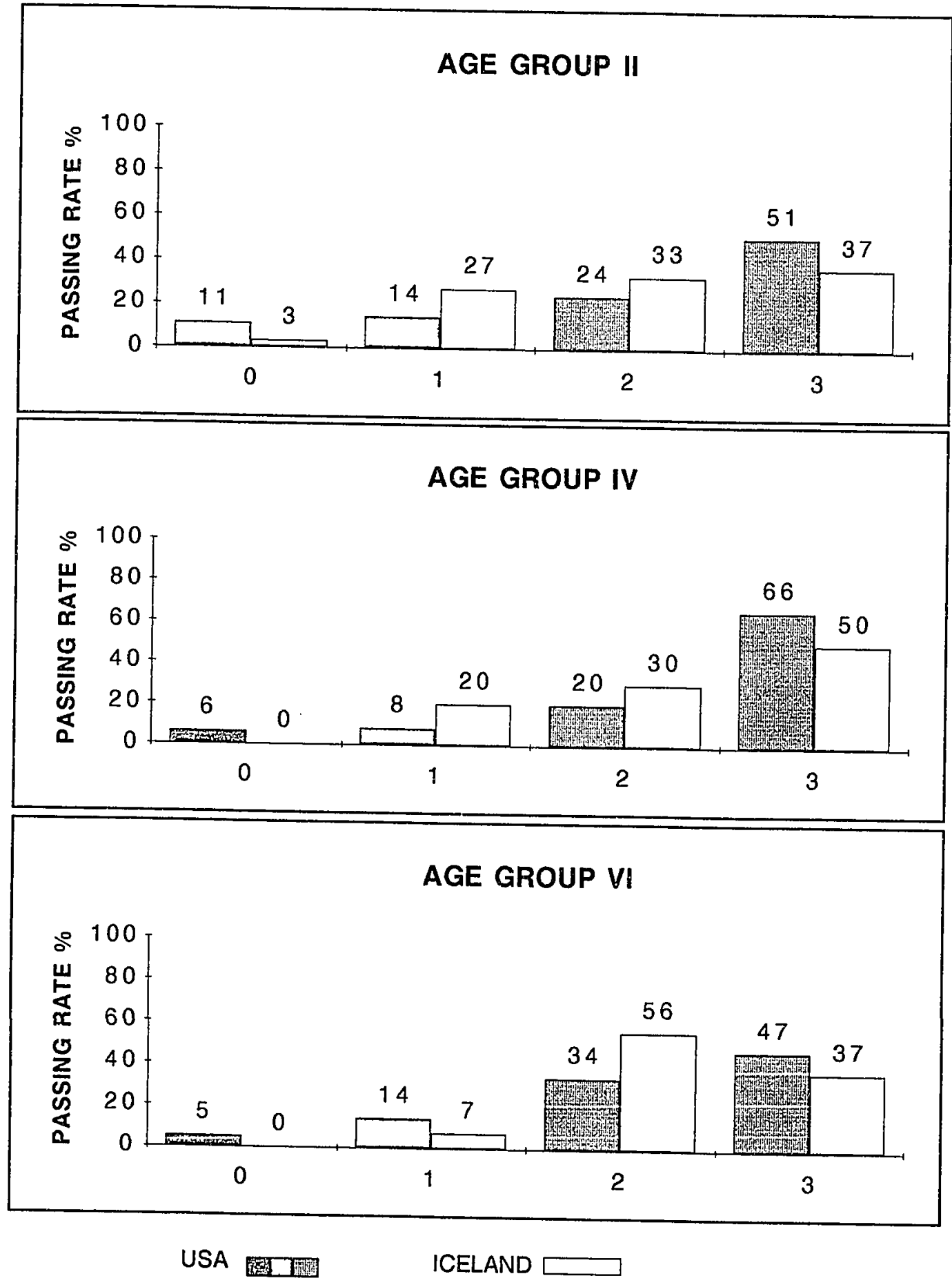

Note. The numbers below the bar graphs indicate subtest raw scores. 
Figure 24. Follow Directions.
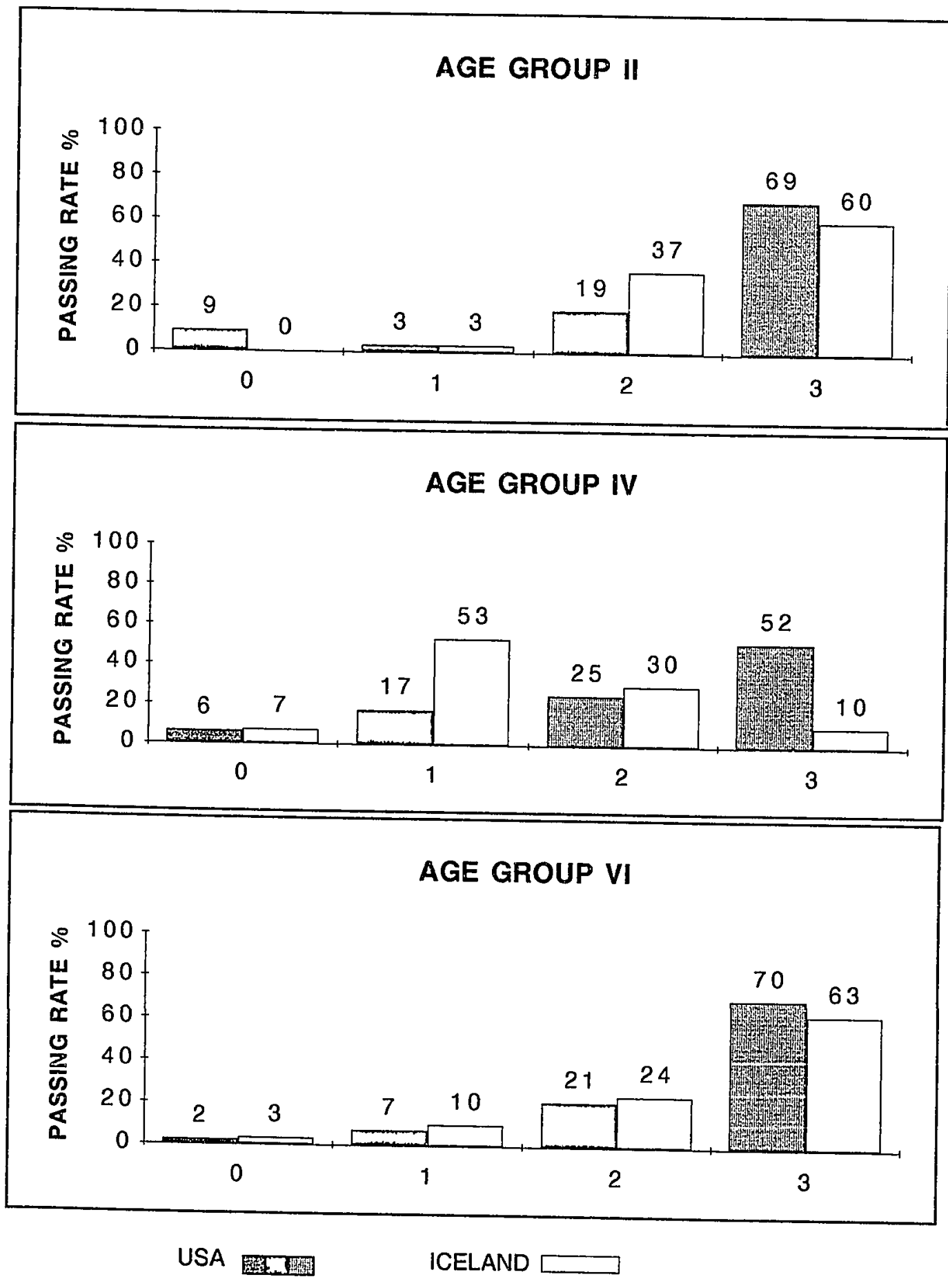

Note. The numbers below the bar graphs indicate subtest raw scores. 
Figure 25. Articulation.
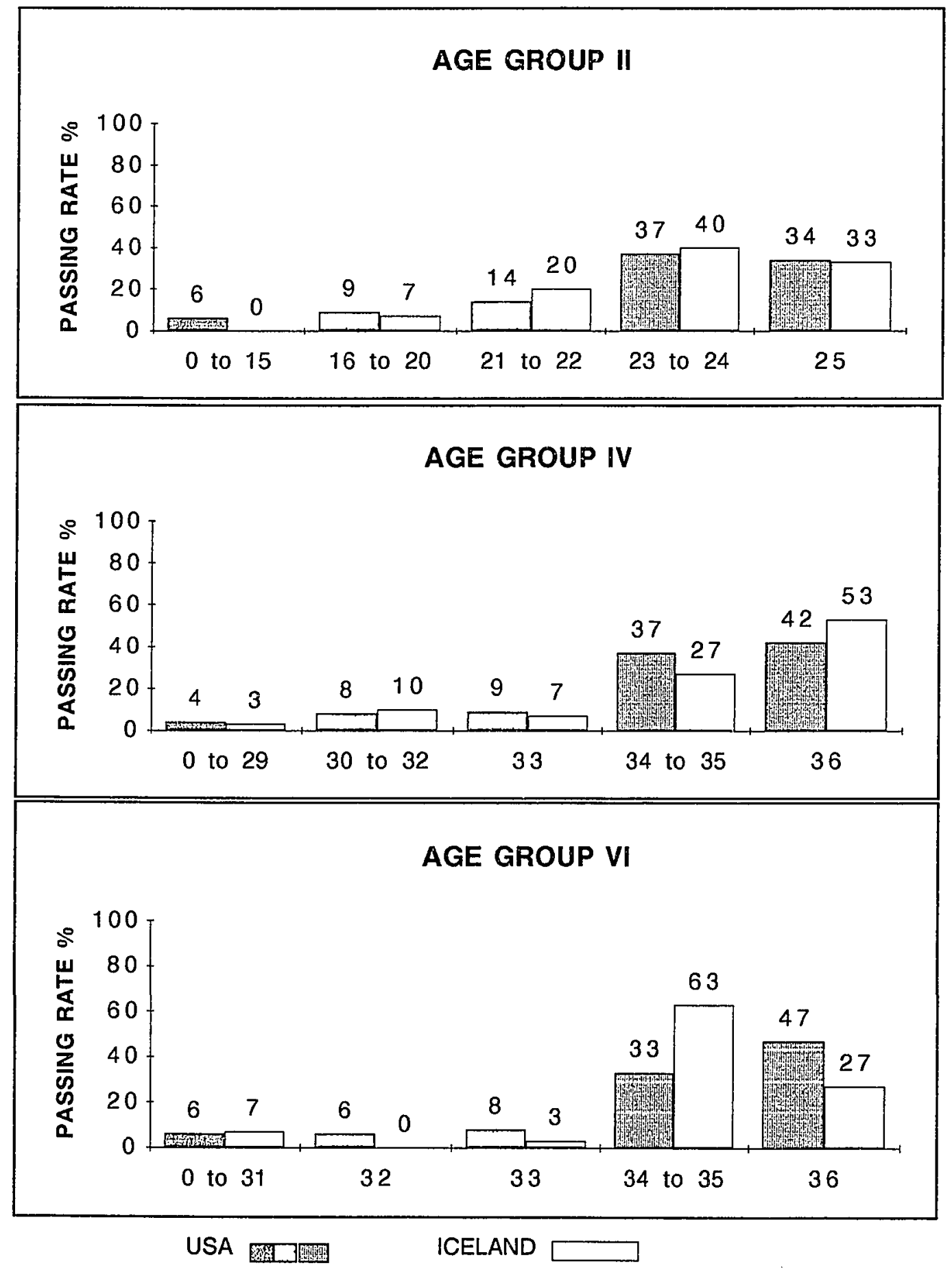

Note. The numbers below the bar graphs indicate subtest raw scores. 
Figure 26. Sentence Repetition.

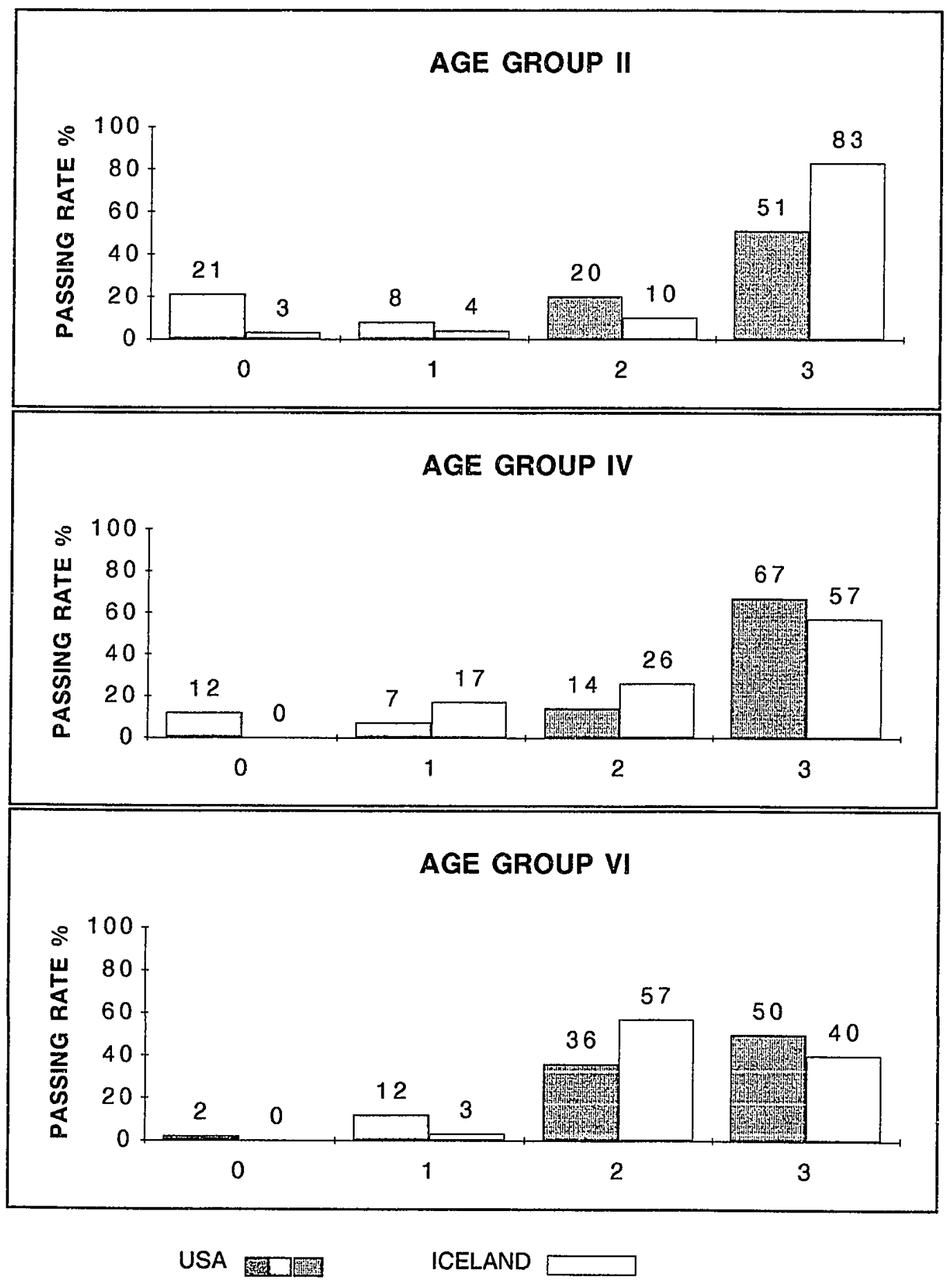

Note. The numbers below the bar graphs indicate subtest raw scores. 
Figure 27. Digit Repetition.

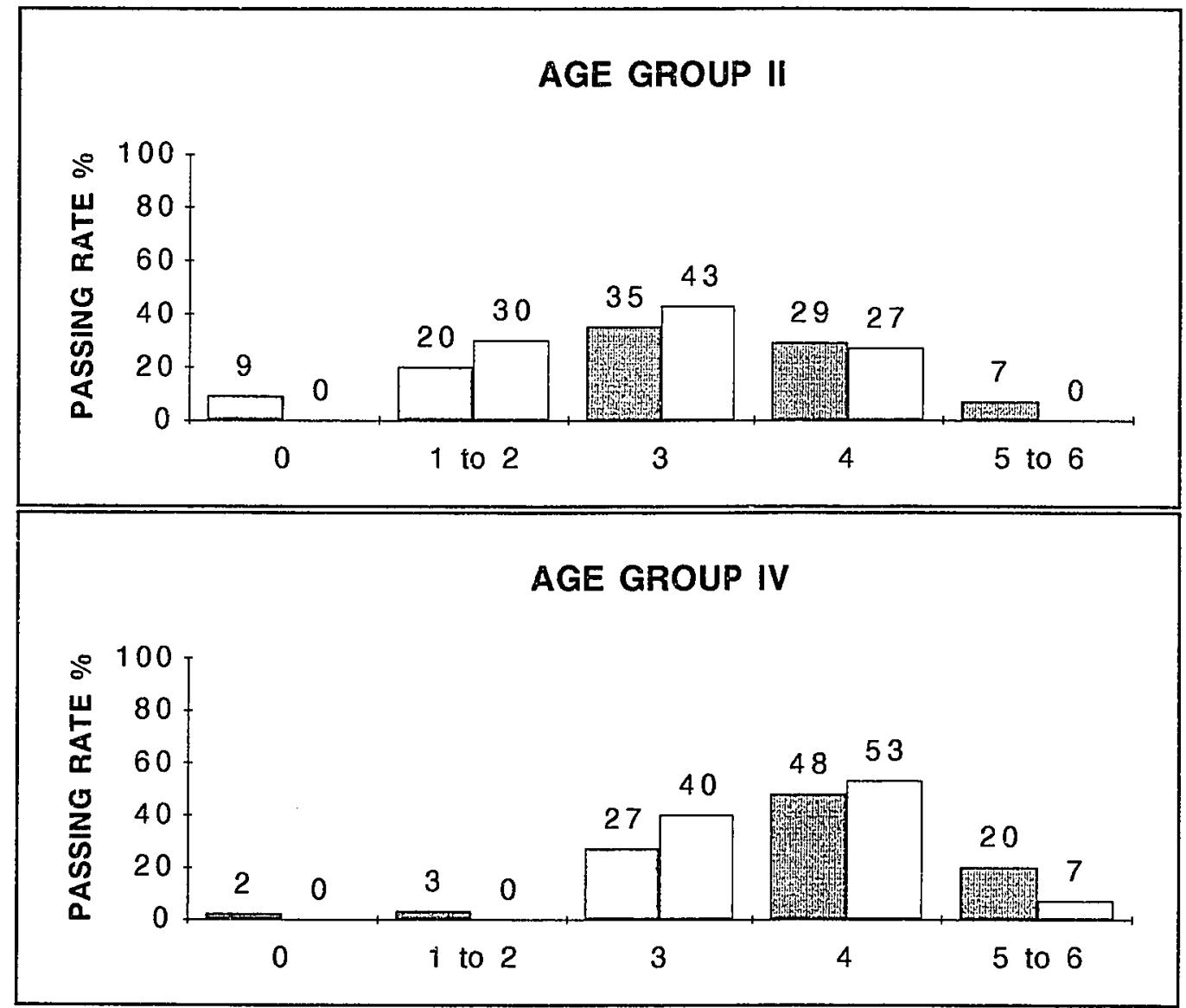

\section{AGE GROUP VI}

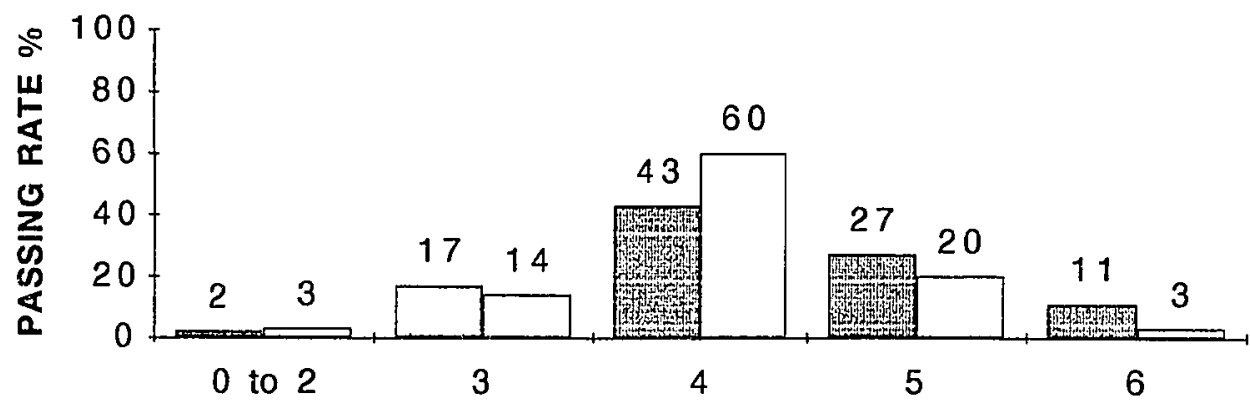

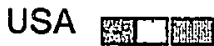

ICELAND

Note. The numbers below the bar graphs indicate subtest raw scores. 
several of the subtests there are minimal differences between the two samples in one or two of the age groups, but noticeable differences at other age levels.

The findings are presented as performance across age groups and across performance indices in terms of noticeable differences in subtest performance between Icelandic and U.S. children on the MAP. Noticeable difference was defined as patterns and trends that emerged to differentiate the two samples. Better performance was defined as obtainment of higher score. The analysis focused on the percentages of Icelandic children classified as "at risk" compared to percentages of U.S. children.

\section{Performance across Age Groups}

\section{Age Group II}

Noticeable differences were found between the Icelandic and U.S. samples on 10 of the subtests. No or minimal differences were obtained on 17 subtests. On five of the subtests, the U.S. children performed better than the Icelandic sample. These subtests are: Block Designs (Figure 3), Vertical Writing (Figure 12), Hand-to-Nose (Figure 13), Romberg (Figure 14), and Stepping (Figure 15). On five other subtests, the Icelandic children performed better. These are the subtests: Tower (Figure 1), Drawa-Person (Figure 10), Tongue Movements (Figure 13), Rapid Alternating 
Movements (Figure 21), and Sentence Repetition (Figure 26).

\begin{abstract}
Age Group IV
Noticeable differences between the two samples were found on 14 of the subtests. No or minimal differences were obtained on 13 of the subtests. On four of the subtests, the U.S. children performed better than the Icelandic sample. These subtests are: Block Designs (Figure 3), Vertical Writing (Figure 12), Stepping (Figure 15) and Follow Directions (Figure 24). On 10 subtests, the Icelandic children performed better. These are the subtests: Sequencing (Figure 2), Block Tapping (Figure 4), Finger Localization (Figure 6), Draw-a-Person (Figure 10), Motor Accuracy (Figure 11), Walks Line (Figure 16), Supine Flexion (Figure 17), Imitation of Postures (Figure 19), Rapid Alternating Movements (Figure 21), and Maze (Figure 22).
\end{abstract}

\title{
Age Group VI
}

Noticeable differences were found between the two samples on 15 of the 27 subtests, whereas no or minimal differences were obtained on 12 subtests. On four of the subtests, the U.S. children performed better than the Icelandic sample. These subtests are: Block Designs ( Figure 3), Motor Accuracy (Figure 11), Stepping (Figure 15), and Walks Line (Figure 
16). On 11 subtests, the Icelandic children performed better. These are the subtests: Sequencing (Figure 2), Block Tapping (Figure 4), Stereognosis (Figure 5), Finger Localization (Figure 6), Puzzles (Figure 8), Hand-to-Nose (Figure 13), Supine Flexion (Figure 17), Tongue Movements (Figure 20), Rapid Alternating Movements, (Figure 21), General Information, (Figure 14), and Sentence Repetition (Figure 26).

\section{Performance across Indices}

Foundations Index

On the Foundations Index, no differences were observed between the two samples on the subtest Kneel-Stand in any of the age groups. On subtest Rapid Alternating Movements, the Icelandic sample performed noticeably better in all age groups, and on Stepping the U.S. children performed better across the three age groups. The Icelandic children in age group II scored at a lower level than their U.S. counterparts on some of the subtests in this Index. Noticeable differences were shown in age group II on the subtests Vertical Writing, Hand-to-Nose, and Romberg, and substantial differences were demonstrated on the subtest Stepping, as displayed in Figure 15. A high percentage of the children in age group II were unable to keep their eyes closed for the twenty second interval required, and some of the older children as well. The Icelandic children in 
age group IV performed better on Walks Line, while the opposite was found for age group VI, as the Icelandic children could not adhere to both the time limit and the accuracy (number of errors) required. Icelandic children in age groups IV and VI performed better on Supine Flexion and Finger Localization. Icelandic age group VI performed better on Stereognosis and Hand-to-Nose.

In summary, in age group II minimal differences were obtained on five subtests, the U.S. sample performed better on four subtests, and the Icelandic sample performed better on one subtest. In age group IV, minimal differences were found on four subtests, the Icelandic children performed better on four subtests, and the U.S. children performed better on two subtests. In age group VI, minimal differences were demonstrated on three subtests, on two of the subtests the U.S. sample performed better, and on the five remaining subtests the Icelandic sample performed better.

\section{Coordination Index}

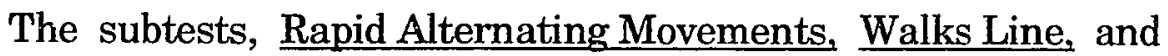
Vertical Writing are included in two Indices, the Coordination and the Foundations Indices, and the results for these three subtests were described above. No differences were found on Articulation across the 
three age groups, although the performance of the Icelandic sample was slightly better in age groups II and VI. The Icelandic sample performed better on Tongue Movements in age groups $\Pi$ II and VI, and the same trend was observed for age group IV. Age group II of the Icelandic sample performed better on Tower. On Motor Accuracy, the Icelandic children in age group IV performed better, but in age group VI the U.S. children performed better.

In summary, in age group II no or minimal differences were shown on three subtests. The U.S. sample performed better on one subtest, and the Icelandic sample performed better on three subtests. In age group IV no or minimal differences were found on three subtests, the U.S. sample performed better on one subtest, and the Icelandic sample performed better on three subtests. In age group VI, no or minimal differences were found on three subtests, the U.S. sample performed better on two subtests, and the Icelandic sample performed better on two subtests.

\section{Verbal Index}

On the Verbal Index, no differences were found between the two samples on Digit Repetition in any of the age groups. In Sentence Repetition, the performance of age groups II and VI was noticeably better among the Icelandic children than among the U.S. children. Age group VI 
of Icelandic children performed better on General Information, but minimal differences were found among the two other age groups. On Follow Directions age group IV of the U.S. children performed substantially better than the Icelandic children in the same age group, but no differences were found in age group $\Pi$ and VI.

In summary, in age group II no or minimal differences were obtained on three subtests, and the Icelandic sample performed better on one subtest. In age group IV, no or minimal differences were found on three of the subtests, and on one subtest the U.S. sample performed better. In age group VI, no or minimal differences were found on two subtests, and the Icelandic sample performed better on two subtests.

\section{Non-Verbal Index}

On the Non-Verbal Index, no differences were found between the two samples on Object Memory and Figure-Ground. The Icelandic children in age groups IV and VI performed better than the U.S. children on Sequencing and Block Tapping. In Puzzles, the Icelandic children in age group VI performed better, and all the Icelandic children accomplished both the tasks required.

In summary, no differences were found between the two samples in age group II. In age group IV, the Icelandic children performed better on 
two subtests, and minimal differences were found on three subtests. In age group VI, the Icelandic children performed better on three out of five subtests, while minimal differences were found on two subtests.

\section{Complex-Tasks Index}

The U.S. children performed better than the Icelandic children in all age groups on Block Designs. In Draw-a-Person, the Icelandic children performed better in age groups II and IV. In Imitation of Postures, the performance of age group II and VI was similar in both samples, but the Icelandic children performed better in age group IV. In Maze, the Icelandic children in age group IV performed better, while minimal differences were found among the remaining age groups.

In summary, in age group II no or minimal differences were obtained on two subtests. The U.S. sample performed better on one subtest, and the Icelandic sample performed better on one subtest. In age group IV differences were obtained on all four subtests, the U.S. children performed better on one subtest, and the Icelandic children performed better on three subtests. In age group VI no or minimal differences were found on three subtests, and on one subtest the U.S. sample performed better. 


\section{Question}

The question to be answered in this study was: Are there noticeable differences in subtest performance between Icelandic and U.S. children on the Miller Assessment for Preschoolers? The findings of the study indicate that there are noticeable differences in performance between the two samples on several of the subtests. In age group II, there are noticeable differences on 10 of the subtests (see Table 6). In age group IV, there are noticeable differences on 14 of the subtests (see Table 7). In age group VI, there are noticeable differences on 15 of the subtests (see Table 8). Table 9 summarizes the overall findings of the study.

\section{Conclusion}

On three subtests, differences were found across all age groups. These are Block Designs, Stepping, and Rapid Alternating Movements. On 19 subtests noticeable differences in performance were found in one or two of the age groups. No differences were found between the two samples on five of the subtests. These are Object Memory, Figure-Ground, Kneel$\underline{\text { Stand, }}$ Articulation, and Digit Repetition. In general, more differences were obtained in subtest performance among the two older age groups of Icelandic and U.S. children than among the youngest age group. On the majority of the subtests where differences were obtained the Icelandic 
Table 6

Comparison of the performance of Icelandic and U.S. children in age group

II on the 27 subtests of the MAP

\begin{tabular}{|c|c|c|c|c|c|}
\hline & $\begin{array}{l}\text { Foundations } \\
\text { Index }\end{array}$ & $\begin{array}{l}\text { Coordination } \\
\text { Index }\end{array}$ & $\begin{array}{l}\text { Verbal } \\
\text { Index }\end{array}$ & $\begin{array}{l}\text { Non-Verbal } \\
\text { Index }\end{array}$ & $\begin{array}{l}\text { Complex Tasks } \\
\text { Index }\end{array}$ \\
\hline Tower & & $\mathrm{XI}$ & & & \\
\hline Sequencing & & & & $\mathrm{O}$ & \\
\hline Block Designs & & & & & X U.S. \\
\hline Block Tapping & & & & $\mathrm{O}$ & \\
\hline Stereognosis & $\mathrm{O}$ & & & & \\
\hline Finger Localization & $\mathrm{O}$ & & & & \\
\hline Object Memory & & & & $\mathrm{O}$ & \\
\hline Puzzles & & & & 0 & \\
\hline Figure-Ground & & & & $\mathrm{O}$ & \\
\hline Draw A Person & & & & & $\mathrm{XI}$ \\
\hline Motor Accuracy & & $\mathrm{O}$ & & & \\
\hline Vertical Writing & X U.S. & X U.S. & & & \\
\hline Hand to Nose & X U.S. & & & & \\
\hline Romberg & X U.S. & & & & \\
\hline Stepping & X U.S. & & & & \\
\hline Walks Line & $\mathrm{O}$ & $\mathrm{O}$ & & & \\
\hline Supine Flexion & $\mathrm{O}$ & & & & \\
\hline Kneel-Stand & 0 & & & & \\
\hline Imitation of Postures & & & & & $\mathrm{O}$ \\
\hline Tongue Movements & & $X I$ & & & \\
\hline Rapid Alt. Movements & $\mathrm{XI}$ & $X I$ & & & \\
\hline Maze & & & & & $\mathrm{O}$ \\
\hline General Information & & & 0 & & \\
\hline Follow Directions & & & $\mathrm{O}$ & & \\
\hline Articulation & & $\mathrm{O}$ & & & \\
\hline Sentence Repetition & & & $X I$ & & \\
\hline Digit Repetition & & & $\mathrm{O}$ & & \\
\hline
\end{tabular}

Note. Minimal differences $=0$, Iceland higher $=$ X I, U.S. higher $=$ X U.S. 
Table 7

Comparison of the performance of Icelandic and U.S. children in age group IV on the 27 subtests of the MAP

\begin{tabular}{|c|c|c|c|c|c|}
\hline & $\begin{array}{l}\text { Foundations } \\
\text { Index }\end{array}$ & $\begin{array}{l}\text { Coordination } \\
\text { Index }\end{array}$ & $\begin{array}{l}\text { Verbal } \\
\text { Index I }\end{array}$ & $\begin{array}{l}\text { Non-Verbal } \\
\text { Index }\end{array}$ & $\begin{array}{l}\text { Complex Tasks } \\
\text { Index }\end{array}$ \\
\hline Tower & & 0 & & & \\
\hline Sequencing & & & & $\mathrm{XI}$ & \\
\hline Block Designs & & & & & X U.S. \\
\hline Block Tapping & & & & $\mathrm{X} I$ & \\
\hline Stereognosis & $\mathrm{O}$ & & & & \\
\hline Finger Localization & XI & & & & \\
\hline Object Memory & & & & $\mathrm{O}$ & \\
\hline Puzzles & & & & $\mathrm{O}$ & \\
\hline Figure-Ground & & & & $\mathrm{O}$ & \\
\hline Draw A Person & & & & & $\mathrm{XI}$ \\
\hline Motor Accuracy & & X I & & & \\
\hline Vertical Writing & X U.S. & X U.S. & & & \\
\hline Hand to Nose & $\mathrm{O}$ & & & & \\
\hline Romberg & $\mathrm{O}$ & & & & \\
\hline Stepping & X U.S. & & & & \\
\hline Walks Line & X I & $\mathrm{XI}$ & & & \\
\hline Supine Flexion & $\mathrm{XI}$ & & & & \\
\hline Kneel-Stand & $\mathrm{O}$ & & & & \\
\hline Imitation of Postures & & & & & $\mathrm{XI}$ \\
\hline Tongue Movements & & $\mathrm{O}$ & & & \\
\hline Rapid Alt. Movements & $\mathrm{XI}$ & $\mathrm{XI}$ & & & \\
\hline Maze & & & & & $\mathrm{XI}$ \\
\hline General Information & & & 0 & & \\
\hline Follow Directions & & & X U.S & & \\
\hline Articulation & & $\mathrm{O}$ & & & \\
\hline Sentence Repetition & & & $\mathrm{O}$ & & \\
\hline Digit Repetition & & & $\mathrm{O}$ & & \\
\hline
\end{tabular}

Note. Minimal differences $=0$, Iceland higher $=$ X I, U.S. higher $=$ X U.S. 
Table 8

Comparison of the performance of Icelandic and U.S. children in age group VI on the 27 subtests of the MAP

\begin{tabular}{|c|c|c|c|c|c|}
\hline & $\begin{array}{l}\text { Foundations } \\
\text { Index }\end{array}$ & \multirow{2}{*}{$\begin{array}{l}\begin{array}{l}\text { Coordination } \\
\text { Index }\end{array} \\
0\end{array}$} & \multirow{2}{*}{$\begin{array}{l}\text { Verbal } \\
\text { Index }\end{array}$} & \multirow[t]{2}{*}{$\begin{array}{l}\text { Non-Verbal } \\
\text { Index }\end{array}$} & $\begin{array}{l}\text { Complex Tasks } \\
\text { Index }\end{array}$ \\
\hline Tower & & & & & \\
\hline Sequencing & & & & $X I$ & \\
\hline Block Designs & & & & & X U.S. \\
\hline Block Tapping & & & & $\mathrm{XI}$ & \\
\hline Stereognosis & $X I$ & & & & \\
\hline Finger Localization & $\mathrm{XI}$ & & & & \\
\hline Object Memory & & & & $\mathrm{O}$ & \\
\hline Puzzles & & & & $\mathrm{XI}$ & \\
\hline Figure-Ground & & & & $\mathrm{O}$ & \\
\hline Draw A Person & & & & & $\mathrm{O}$ \\
\hline Motor Accuracy & & X U.S. & & & \\
\hline Vertical Writing & O. & $\mathrm{O}$ & & & \\
\hline Hand to Nose & $X I$ & & & & \\
\hline Romberg & $\mathrm{O}$ & & & & \\
\hline Stepping & X U.S. & & & & \\
\hline Walks Line & X U.S. & X U.S. & & & \\
\hline Supine Flexion & $\mathrm{XI}$ & & & & \\
\hline Kneel-Stand & $\mathrm{O}$ & & & & \\
\hline Imitation of Postures & & & & & $\mathrm{O}$ \\
\hline Tongue Movements & & $X I$ & & & \\
\hline Rapid Alt. Movements & $\mathrm{XI}$ & $\mathrm{XI}$ & & & \\
\hline Maze & & & & & $\mathrm{O}$ \\
\hline General Information & & & $X I$ & & \\
\hline Follow Directions & & & $\mathrm{O}$ & & \\
\hline Articulation & & $\mathrm{O}$ & & & \\
\hline Sentence Repetition & & & $\mathrm{XI}$ & & \\
\hline Digit Repetition & & & $\mathrm{O}$ & & \\
\hline
\end{tabular}

Note. Minimal differences $=0$, Iceland higher $=$ X I, U.S. higher $=$ X U.S. 
Table 9

Differences in subtest performance between the Icelandic and the U.S. samples

\begin{tabular}{|c|c|c|c|}
\hline & Age group II & Age group IV & Age group VI \\
\hline Tower & X I & $\mathrm{O}$ & $\mathrm{O}$ \\
\hline Sequencing & $\mathrm{O}$ & X I & X I \\
\hline Block Designs & X U.S. & X U.S. & X U.S. \\
\hline Block Tapping & $\mathrm{O}$ & $\mathrm{XI}$ & $\mathrm{X} \mathrm{I}$ \\
\hline Stereognosis & $\mathrm{O}$ & $\mathrm{O}$ & X I \\
\hline Finger Localization & $\mathrm{O}$ & X I & $\mathrm{X} \mathrm{I}$ \\
\hline Object Memory & $\mathrm{O}$ & $\mathrm{O}$ & $\mathrm{O}$ \\
\hline Puzzles & $\mathrm{O}$ & $\mathrm{O}$ & $X I$ \\
\hline Figure-Ground & $\mathrm{O}$ & $\mathrm{O}$ & $\mathrm{O}$ \\
\hline Draw-a-Person & X I & X I & $\mathrm{O}$ \\
\hline Motor Accuracy & O & $\mathrm{XI}$ & X U.S. \\
\hline Vertical Writing & X U.S. & X U.S. & $\mathrm{O}$ \\
\hline Hand to Nose & X U.S. & $\mathrm{O}$ & $X I$ \\
\hline Romberg & X U.S. & $\mathrm{O}$ & $\mathrm{O}$ \\
\hline Stepping & X U.S. & X U.S. & X U.S. \\
\hline Walks Line & $\mathrm{O}$ & X I & X U.S. \\
\hline Supine Flexion & $\mathrm{O}$ & X I & X I \\
\hline Kneel-Stand & $\mathrm{O}$ & $\mathrm{O}$ & $\mathrm{O}$ \\
\hline Imitation of Postures & $\mathrm{O}$ & X I & $\mathrm{O}$ \\
\hline Tongue Movements & X I & $\mathrm{O}$ & X I \\
\hline Rapid Alt. Movements & $\mathrm{X} \mathrm{I}$ & $\mathrm{XI}$ & X I \\
\hline Maze & $\mathrm{O}$ & $\mathrm{XI}$ & $\mathrm{O}$ \\
\hline General Information & $\mathrm{O}$ & $\mathrm{O}$ & $\mathrm{X} I$ \\
\hline Follow Directions & $\mathrm{O}$ & X U.S. & $\mathrm{O}$ \\
\hline Articulation & $\mathrm{O}$ & $\mathrm{O}$ & $\mathrm{O}$ \\
\hline Sentence Repetition & $\mathrm{X} I$ & $\mathrm{O}$ & X I \\
\hline Digit Repetition & $\mathrm{O}$ & $\mathrm{O}$ & $\mathrm{O}$ \\
\hline
\end{tabular}

Note. Minimal differences $=0$, Iceland higher $=$ X I, U.S. higher $=$ X U.S. 
children performed more efficiently if focused on number of children within Red and Yellow categories, that is, how the test classified Icelandic and U.S. children as "at risk." In conclusion, there appear to be noticeable differences in performance between the Icelandic sample and the U.S. normative sample on majority of the subtests of the MAP. These results relate only to age groups II, IV and VI. 


\section{CHAPTER 5}

\section{SUMMARY, DISCUSSION, IMPLICATIONS, AND RECOMMENDATIONS}

\section{Summary}

This study was designed to determine whether there are noticeable differences in performance between U.S. and Icelandic children on the 27 subtests of the MAP. A review of the literature indicated that differences in child development exist across cultures, and advised cautious use and interpretation of test norms in a different population than in that which the test was standardized.

Ninety Icelandic children in three age groups participated in this study. All subjects were tested with the MAP. A descriptive design was used for the comparison of subtest performance between the Icelandic children and the U.S. normative sample.

The findings of the study indicate that there appear to be minimal differences in performance between the Icelandic sample and the U.S. normative sample on several of the subtests of the MAP. On other subtests, however, there appear to be noticeable differences if focused on differences within low scores and how the test classifies Icelandic and U.S. 
children as at risk.

This research provides a reference point for therapists involved with testing and identifying Icelandic children with suspected academic problems. Furthermore, it indicates that further research may be necessary to determine the applicability of the MAP in Iceland.

\section{Discussion}

In general, less range was obtained on several of the subtest scores in this study than within the U.S. standardization sample. Hence, the Icelandic children obtained fewer of the very low scores, but also did not obtain as many of the highest scores possible. This affects the interpretation of the data, as the study focused on differences within low scores (Red, and Yellow categorys), and emphasis on differences within high scores (Green category) was minimal.

Less range may be an artifact of a much smaller sample, but quite possibly the homogeneity of the Icelandic population may be a contributing factor as well. The sample $(n=90)$ in this study is a limitation, as stated in chapter 1 . However, in Iceland there exists a Census list of all citizens. As the sample was recruited from this list and attrition was minimal, it can be assumed that the sample was quite representative of Icelandic children in the capital area. Several countries do not have a 
Census list, and often a selective factor like a nursery school or a day-care center is used to recruit the subjects in similar studies. It is possible that such a method of selection may contribute a confounding variable.

No differences were found between the two samples on five of the subtests. These are Object Memory (Non-Verbal Index), Figure-Ground (Non-Verbal Index), Kneel-Stand (Foundations Index), Articulation (Coordination Index), and Digit Repetition (Verbal Index). On all other subtests there were noticeable differences in performance in some of the age groups. On three subtests, differences were found across all age groups. The U.S. children performed better on Block Designs (ComplexTasks Index), Stepping (Foundations Index) in all age groups, and the Icelandic children performed better on Rapid Alternating Movements in all age groups (Foundations and Coordination Indices). It appears that the differences obtained between the two samples are fairly evenly spread across Indices, as on some of the subtests within an Index, the U.S. children obtained a higher score and on other subtests the Icelandic children showed better skill. An exception is the Non-Verbal Index where the overall performance of age groups IV and VI of the Icelandic sample seemed to be noticeably better than that of the U.S. children. Substantial differences were also obtained in age group II on the Foundations Index, where the Icelandic children demonstrated noticeably poorer overall 
performance. The Foundations and Coordination Indices include the most items and each of them assesses not a single domain, but a variety of behaviors. It appears that some of the subtests in these Indices that necessitated occlusion of vision, and combination of speed and motor accuracy caused difficulty for the Icelandic sample, as well as those that required maintainance of position while stepping or writing. In general, more differences were obtained in subtest performance among the two older age groups of Icelandic and U.S. children than among the youngest age group. On the majority of the subtests where differences occurred, the Icelandic children seemed to perform more efficiently if focused on differences within low scores, and how the test classified Icelandic and U.S. children as "at risk." The greatest differences between the two samples were obtained on the subtest Stepping where the U.S. children performed substantially better as displayed in Figure 15. A high percentage of the Icelandic children in age group II were unable to keep their eyes closed for the twenty second interval required, and some of the older children as well. Substantial differences were also obtained in age group VI on Walks Line (table 15), as the Icelandic children had difficulties adhering to both the time limit and the accuracy required (number of errors).

The relatively same trend was not necessarily found within all three age groups on several of the subtests. Hence, the Icelandic children 
performed similarly to the U.S. normative sample on a few of the subtests in one or two age groups, but noticeable differences were found in other age groups. The U.S. sample performed better on Hand to Nose in age group II while the Icelandic sample performed better in age group VI. On Walks Line the U.S. sample performed substantially better in age group VI, but the Icelandic sample performed better in age group IV. On Follow Directions, the performance of the two samples was quite similar for age group II and VI but noticeable differences were obtained for age group IV, where the U.S. sample performed substantially better than their Icelandic counterparts. This finding may reveal the necessity of studying the translation of the specific items in the subtest, to determine whether this may have contributed to this result. Another possible explanation is that the MAP's item content varies across age groups. Hence, the materials used for several of the subtests are different for each age group, which may imply differences in item difficulty and distribution. Comparison of the other subtests in the Verbal Index did not indicate specific problems with the Icelandic translation, and differences within this Index were not more prominent than within other Indices.

Minimal differences were obtained between the performance of the Icelandic children in age groups IV and VI on a few of the subtests and on Romberg, the raw score and the percentile ranking of the younger age 
group was slightly higher than of age group VI. It is not clear whether these findings are artifacts of the sample tested or whether the subtest does not discriminate appropriately between these age groups of Icelandic children. In Puzzle, age group VI, all of the Icelandic children succeeded in performing the two tasks required. Hence, the subtest was not sensitive to children who might be "at risk" in this age group.

Today, several countries are conducting crosscultural research on the MAP. It would be valuable to compare the results from the different studies to determine if differences occur more on certain items than on others. Some of the subtests of the MAP are thought to measure central nervous system maturity, especially the scales in the Foundation Index. Other subtests are more related to learned behavior (Cognitive and Combined abilities). Hence, it would be interesting to explore and determine, if possible, if the differences obtained appear to be due to genetic influences, or to cultural variations. However, as the procedures, and research designs that are utilized in each country vary, it may be difficult to compare the findings.

Several of the findings of this study are in accordance with the results from the crosscultural study that was undertaken in Israel (Schneider, Parush, Katz, \& Miller, 1993). The Israeli children performed at a significantly lower level than the U.S. sample on the Foundations Index. 
The Icelandic children in age group II also performed at substantially lower level than the U.S. children, but it would seem that the overall differences among age group IV and VI are not as striking, as on some of the subtests the U.S. children performed better, but on other subtests the Icelandic children performed better. Furthermore, it appears that the Israeli children had problems with some of the same subtests in the Index as the Icelandic children in this study (Stepping, Vertical Writing, and Walks Line). However, on subtest Rapid Alternating Movements, the Israeli children performed at a lower level than the U.S. children, which is opposite of the finding among the Icelandic children. On a few subtests, the Israeli children performed at a significantly higher level than their U.S. counterparts (Puzzle and Finger_Localization). The Icelandic children also demonstrated somewhat better performance than the U.S. sample on these items, although it is not known whether the differences are significant. The Israeli study only included age groups II and VI. Information on the performance of Israeli children in age group IV was not obtained and, therefore, cannot be compared.

In the crosscultural study that was undertaken in Japan, publications to date include results of only nine subtests were compared to the U.S. normative data. Hence, it is more difficult to compare their results to the findings obtained in this study. In general, the Japanese 
children performed significantly better than the U.S. children on items related to eye-hand coordination. On two subtests (Supine Flexion and Tongue Movements) the U.S. children performed significantly better. As information is missing on 16 of the subtests, it is not possible to compare the overall performance on the 27 subtests. However, from the information available there appear to be differences in performance between Japanese and Icelandic children. As an example, in two of three age groups the Icelandic children performed better than the U.S. sample on Tongue Movements and Supine Flexion, and minimal differences were found in one age group.

\section{Implications}

Comparability of a test among different cultural groups is an important issue in crosscultural research, as stated in chapter 2 . The aspects of instrument bias and validity are of particular importance and should be addressed and studied. According to Gregory (1992) an essential criterion of nonbias is that the factor structure of test scores should remain invariant across respective population. The sample size in this study did not allow a meaningful factor analysis. A second criterion of nonbias in construct validity is that the rank order of item difficulty within a test should be highly similar for the two populations (Jensen, 1980). 
This study demonstrated noticeable differences on several of the subtests, however, the study did not address the rank order of items within subtests. Hence, the question of bias is not answered in this study. Further studies on the MAP in Iceland may be needed to assure valid decisions about the presence of dysfunction in Icelandic children, and thus to determine the applicability of the test within the Icelandic preschool population. It is desirable to study the MAP in Iceland independent of its use in the United States, as well as to further compare the performance of Icelandic and U.S. children . As the raw scores from the U.S. standardization sample were unavailable, it was not possible to test statistically whether there are significant differences between the two samples. Furthermore, this study focused on performance on the 27 subtests of the MAP only. It did not establish how subtest scores of the Icelandic sample translate into Total Score and Performance Index Scores. According to the author, Dr. Lucy Jane Miller, a new standardization of the MAP is planned in the United States in the near future. In the new version of the scale, the norms will be presented in standard scores. This will provide opportunity for a more extensive comparison, as well as research on the technical adequacy of the test within the Icelandic preschool population. 
The MAP has not been used as a screening tool in Iceland to assign children into different programs. Therefore, the issue of the established cutpoints has not been essential, except for their effect on the Total Score. This study provides some information on how the test distinguishes between Icelandic children. However, it is necessary to examine further the usefulness of the cutpoints for the Icelandic preschool population if they are to be used to determine the need for intervention. Furthermore, it would also be valuable to study score patterns among various Icelandic clinical groups and samples of exceptional children and compare these with the MAP score patterns based on an U.S. dysfunctional population. (Miller, 1988b)

\section{Recommendations}

As a result of this study, a number of recommendations can be made for further research to determine the applicability of the MAP for the Icelandic preschool population.

\section{Crosscultural Comparisons:}

1. Instrument bias.

- Examine whether the factor structure of test scores is the same within the Icelandic and the U.S. population. 
- Determine further whether test items are relatively easier or more difficult for the Icelandic preschool population than for the U.S. population.

Study the MAP in Iceland independent of its use in the United States:

1. Content validity: Study the degree to which the items on the MAP are representative of the behavior of Icelandic preschoolers that the scale was designed to sample.

2. Concurrent validity: Compare the MAP to other scales to provide evidence of the convergent and discriminant validity of the MAP within the Icelandic preschool population.

3. Temporal Stability: Administer the MAP twice to the same group of children over time and determine the test-retest correlation coefficient within the Icelandic preschool population.

4. Predictive validity: Determine the value of the MAP as a predictor of later school problems within the Icelandic preschool population.

5. Examine further the usefulness of the $5 \%$ and $25 \%$ cutpoints for the Icelandic preschool population.

6. Study score patterns among an Icelandic dysfunctional population and compare these with MAP score patterns based on a U.S. dysfunctional population. 


\section{References}

American Psychological Association. (1974). Standards for educational and psychological tests. Washington, D.C.

Anastasi, A. (1988). Psychological testing. New York: Macmillan.

Arnkelsson, G. B. (1988). Psychological tests. The Icelandic Journal of Psychology, 10 (2), 4-32. (Translation from Icelandic).

Bracken, B. A. (1987). Limitations of preschool instruments and standards for minimal levels of technical adequacy. Journal of Psychoeducational Assessment, 4 , 313-326.

DeGangi, G. A. (1983). A critique of the standardization of the Miller Assessment for Preschoolers. American Journal of Occupational Therapy, 37, 407-411.

Daniels, L. E., \& Bressler, S. (1990). The Miller Assessment for Preschoolers: Clinical use with children with developmental delays. American Journal of Occupational Therapy, 44, 48-53.

Deloria, D. J. (1985). Review of Miller Assessment for Preschoolers. The ninth mental measurements yearbook. Lincoln, NE: Buros Institute of Mental Measurements, University of Nebraska.

Campbell, S. K. (1989). Measurement in developmental therapy: Past, 
present, and future. In L. J. Miller (Ed.), Developing normreferenced standardized tests (pp. 1-13). New York: The Haworth Press.

Frankenburg, W. K, Dick, N. P., \& Carland, J. (1980). Development of preschool-age children of different social and ethnic groups: Implications for developmental screening. The Journal of Pediatrics, 87, 125-132.

Frankenburg, W., Dodds, J., Fandal, A., Kazuke, E., \& Cors, M. (1975). Denver Developmental Screening Test-Revised; Reference manual. Denver: Ladoca.

Humphry, R., \& King-Tomas, L. (1993). A response and some facts about the Miller Assessment for Preschoolers. The Occupational Therapy Journal of Research, $13,35-49$.

Jensen, A. (1980). Bias in mental testing. New York: Macmillan Publishing.

Kaplan, H., \& Dove, H. (1987). Infant development among the Ache of eastern Paraguay. Developmental Psychology, 23, 190-198.

Lichtenstein, R., \& Ireton, H. (1991). Preschool screening for developmental and educational problems. In B. A. Bracken (Ed.), The psychoeducational assessment of preschool children (2nd ed., pp. 486-513). Needham Heights, MA: Simon \& Schuster. 
Mardell-Czudnowski, C., Chien-Hou, H., \& Tien-Miau, W. (1986). Crosscultural adaptation of a developmental test (DIAL-R) for young children in Taiwan. Journal of Cross-Cultural Psychology, 17, 475- 492.

McCauley, R., \& Swisher, L. (1984). Psychometric review of language and articulation tests for preschool children. Journal of Speech and Hearing Disorders, $\underline{49}, 34-41$.

Miller, L. J., (1988a, 1982). The Miller Assessment for Preschoolers (MAP). San Antonio, TX: The Psychological Corporation.

Miller, L. J., (1988b, 1982). The Miller Assessment for Preschoolers : Seminar administration \& interpretation. San Antonio, TX: The Psychological Corporation.

Miller, L. J., (1983). Procedures for standardization in foreign countries. Unpublished manuscript. Littleton, CO: The Foundation for Knowledge in Development.

Miller, L. J., (1993). First STEP (Screening Test for Evaluationg Preschoolers): Manual. San Antonio, TX: The Psychological Corporation.

Miller, L. J., \& Lemerand, P. A., (1986). Brief - Neuromaturational variables within the Miller Assessment for Preschoolers. Occupational Therapy Journal of Research, $\underline{6}, 123-125$. 
Miller, L. J., Lemerand, P. A., \& Cohn, S. H. (1987). Brief - A summary of three predictive studies with the MAP. Occupational Therapy Journal of Research, $\underline{7}, 378-381$.

Miller, L. J., \& Sprong, T. A. (1986). Psychometric and qualitative comparison of four preschool screening instruments. Journal of Learning Disabilities, $\underline{19}, 480-484$.

Ólafsson, S. (1990). Lifskjör og lífshættir á Íslandi. (Standards and ways of living in Iceland). Reykjavík: Hagstofa Íslands og Félagsvísindastofnun.

Saeki, K, Clark, F. A., \& Azen, S. P. (1985). Performance of Japanese and Japanese-American Children on the Motor Accuracy-Revised and Design Copying Tests of the Southern California Sensory Integration Tests. The American Journal of Occupational Therapy, $\underline{39}$, 103-109.

Schneider, E., Parush, S., Katz, N., \& Miller, L. J. (1993). Performance of Israeli and U.S. Preschool children on the Miller Assessment for Preschoolers - A pilot study. Manuscript submitted for publication. Schouten, P. G. W., \& Kirkpatrick, L. A. (1993). Questions and concerns about the Miller Assessment for Preschoolers. The Occupational Therapy Journal of Research, $\underline{13}, 7-28$. 
Sæmundsen, E., Halldórsson, J. G., \& Arnljótsdóttir, M. (1990). Sensory - motor development in 90 Icelandic infants (aged 6-10 months) studied by the Bayley scales. Journal of the Icelandic Psychologist Association, 1, 7-17.

Tsuchida, R. (1992). Performance of Japanese children on the Japanese version of the Miller Assessment for Preschoolers. Symposium '92 Proceedings: Current Topics in Sensory Integration. Torrance, CA: Sensory Integration International

Williams, P. D., \& Williams, A. R. (1987). Denver developmental screening test norms: A cross-cultural comparison. Journal of Pediatric Psychology, 12, 39-59.

Wolanski, N. (1987). A call for interest in collaborative cross-cultural research on infant motor development. Physical \& Occupational Therapy in Pediatrics, $1,1-2$. 


\section{APPENDIX A}

Figures displaying the percentile rank order for the Icelandic and U.S. samples 
Figure A-1. Reference guide for item score sheet. Icelandic age group IIa $\left(3^{\prime} 3-3^{\prime} 8\right)$

PERCENTILE \%

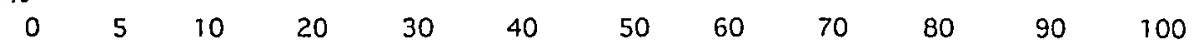

Tower

\begin{tabular}{|c|c|c|c|c|c|c|c|c|c|}
\hline 7 & 8 & 9 & 10 & 11 & 12 & 13 & 14 & 15 \\
\hline 3
\end{tabular}

Sequencing

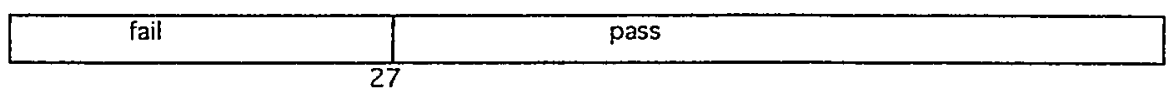

Block Designs

\begin{tabular}{|l|l|l|}
\hline neither & only one & both \\
\hline 17 & 47 &
\end{tabular}

Block Tapping

neither

\begin{tabular}{|c|c|}
\hline only one & both \\
\hline 43 & 70
\end{tabular}

Stereognosis

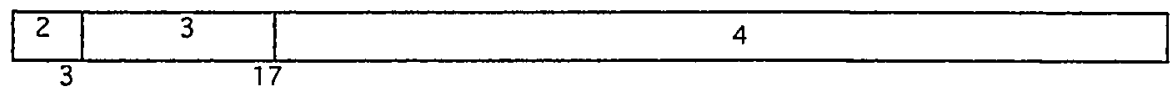

Finger Loc.

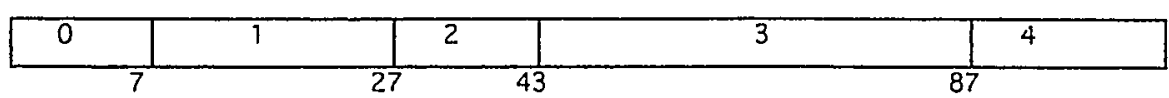

Obj. Memory

\begin{tabular}{|l|r|r|r|}
\hline neither & m. fork & miss ball & both \\
\hline 7 & 17 & 53 &
\end{tabular}

Puzzles

\begin{tabular}{|l|l|l|}
\hline neither & only one & both \\
\hline 7 & & \\
\hline
\end{tabular}

Fig.-Ground

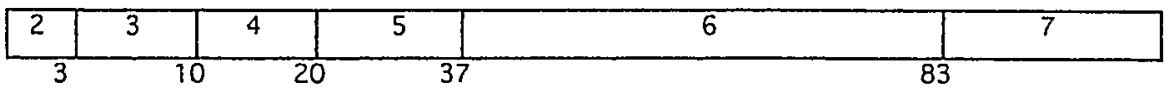

Draw-Person

\begin{tabular}{|r|r|r|r|r|r|r|r|r|r|r|}
\hline 0 & 1 & 2 & 3 & 4 & 5 & 7 & 8 & $9-11$ & 12 \\
\hline
\end{tabular}

Motor Acc.

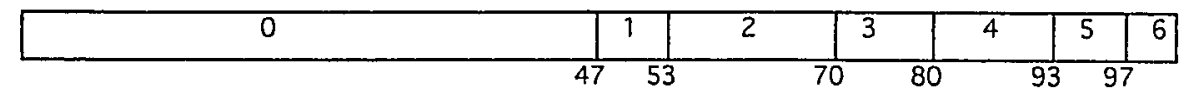

Vert. Writing

\begin{tabular}{|l|l|l|l|l|l|l|l|l|l|l|}
\hline unable & 17 & $16-13$ & -11 & -9 & & 8 & $7-6$ & $5-4$ & 2 \\
\hline 3033 & 40 & 50 & 60 & 70 & 84 & 90 \\
\hline
\end{tabular}

Hand-Nose

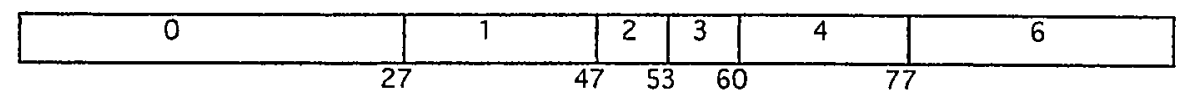

Romberg

\begin{tabular}{|l|l|l|l|l|l|l|l|}
\hline 0 & 3 & 5 & 8 & 9 & 10 & 12 & 15 \\
\hline 3 & 10 & 17 & 20 & 30 & 3740
\end{tabular}


Figure A-2. Reference guide for item score sheet. Tcelandic age group $\Pi$ lb $\left(3^{\prime} 3-3^{\prime} 8\right)$

PERCENTILE \%

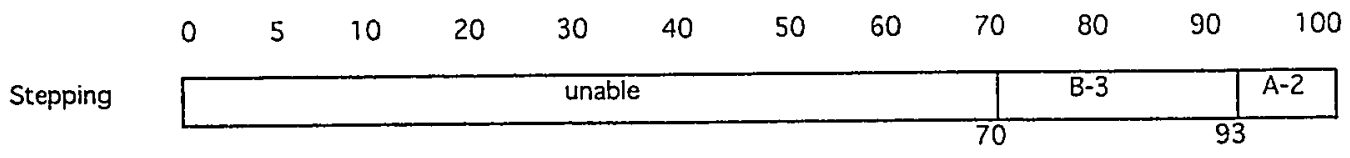

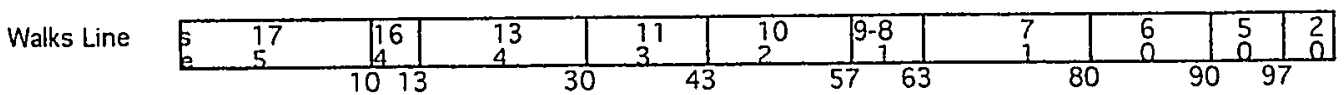

\begin{tabular}{l|l|l|l|l|l|l|ll|l|l|}
\hline 0 & 2 & 3 & 4 & 5 & & 6 & 9 & $10-7315$ \\
\hline 27 & 40 & 53 & 57 & 60 & & 83 & 90 & 97 \\
\hline
\end{tabular}

\begin{tabular}{l|l|l|l|}
\hline Kneel-Stand & only one & both \\
\cline { 2 - 3 } & neither & 47 & \\
\hline
\end{tabular}
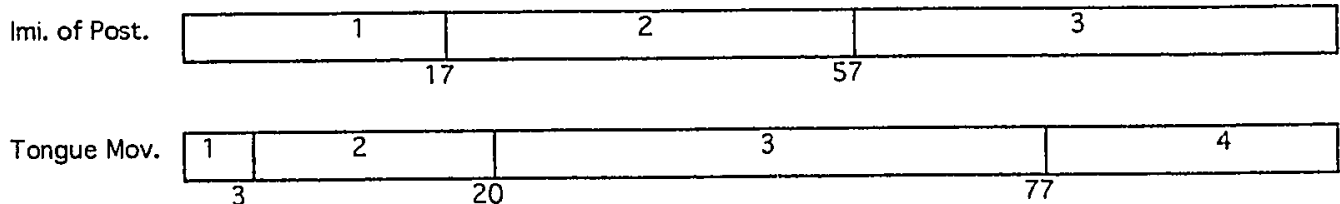

Rap. Alt. Mov. \begin{tabular}{|l|l|l|l|l|l|l|l|l|}
\hline unable & 11 & 10 & & 9 & 8 & 7 & 6 & 5 \\
\hline 7 & 13 & 20 & & 40 & 50 & 67 & 80
\end{tabular}

\begin{tabular}{|l|l|l|l|l|l|l|l|l|l|}
\hline Maze & unable & 12 & 11 & 7 & 6 & 5 & 4 & 3 & 2 \\
\hline
\end{tabular}

Gen. Inf. \begin{tabular}{|l|l|l|r|r|}
\hline 0 & 1 & 2 & 3 \\
\hline 3 & 30 & 63 & 3 \\
\hline
\end{tabular}
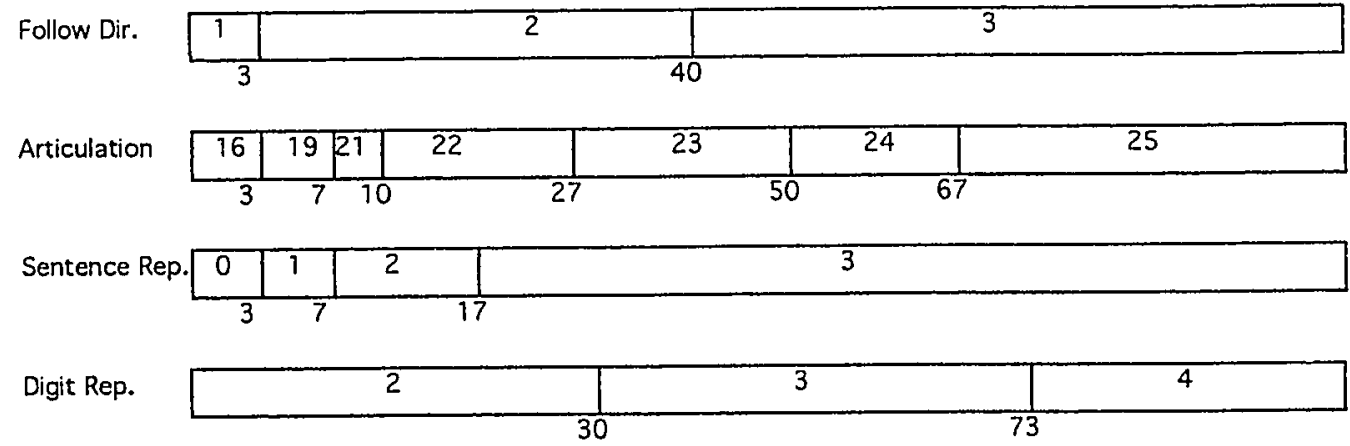
Figure A-3. Reference guide for item score sheet. Icelandic age group IVa $\left(4^{\prime} 3-4^{\prime} 8\right)$.

PERCENTILE \%

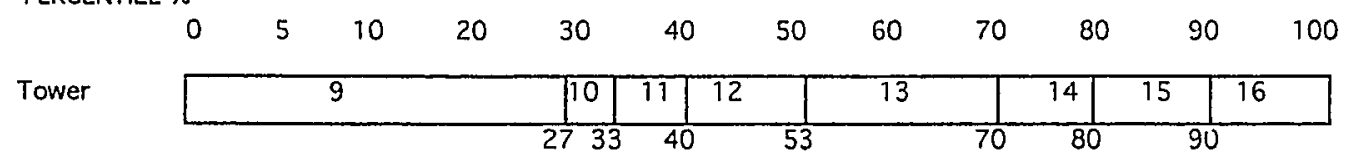

Sequencing \begin{tabular}{|l|l|}
\hline fail & pass \\
\hline 3
\end{tabular}

Block Designs \begin{tabular}{|l|l|l|}
\hline neither & miss stairs & both \\
\hline 13 & 30
\end{tabular}

Block Tapping \begin{tabular}{|c|c|c|}
\hline$n$ & only one & both \\
\hline 3 & 20
\end{tabular}

Stereognosis \begin{tabular}{|l|l|}
\hline 3 & \\
\hline
\end{tabular}
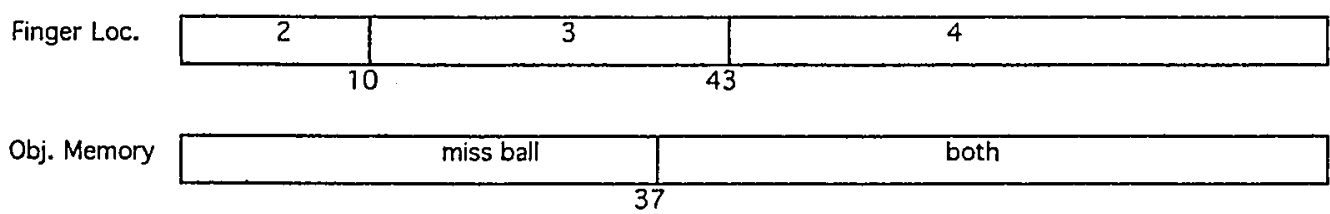

\begin{tabular}{|l|r|r|}
\hline Puzzles & only one & both \\
\hline 10 & 27
\end{tabular}

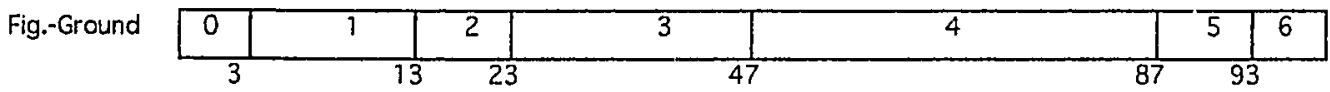

Draw-Person \begin{tabular}{|l|l|l|l|l|l|l|l|l|l|l|l|l|l|l|}
\hline 0 & 4 & 5 & 6 & 7 & & 8 & 9 & 10 & 11 & 12 & 13 & 14 & 15 & 20 \\
\hline 3
\end{tabular}

\begin{tabular}{l|l|l|l|l|l|l|l|l|l|l|l|l|l|}
\hline 2 & 3 & 4 & 5 & 6 & 7 & 8 & 9 & 10 & 11 & 12 \\
\hline
\end{tabular}

\begin{tabular}{l|l|l|l|l|l|l|l|l|l|l|l|l|l|l|}
\hline Vert. Writing & 12 & 11 & 10 & 9 & 8 & 7 & 6 & 5 & 4 & 3 & 2 \\
\hline
\end{tabular}

Hand-Nose

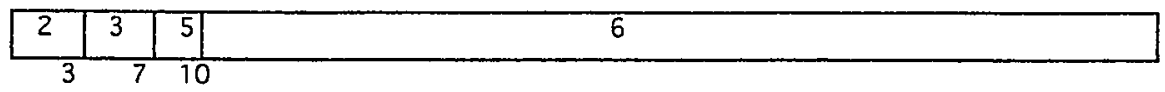

Romberg

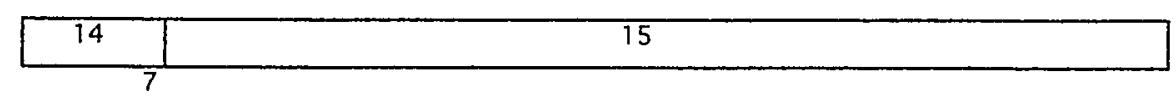


Figure A-4. Reference guide for item score sheet. Icelandic age group IVb $\left(4^{\prime} 3-4^{\prime} 8\right)$.

PERCENTILE \%

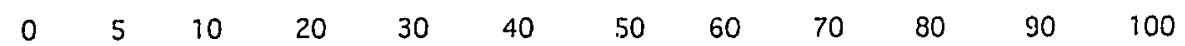

Stepping

\begin{tabular}{|c|c|c|c|c|c|}
\hline$D-5$ & $C-3$ & $B-3$ & $A-2$ & $A-1$ \\
\hline 7 & 37 & 53 & 60 & \\
\hline
\end{tabular}

Walks Line

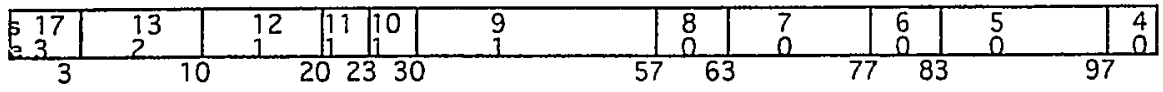

Sup. Flexion

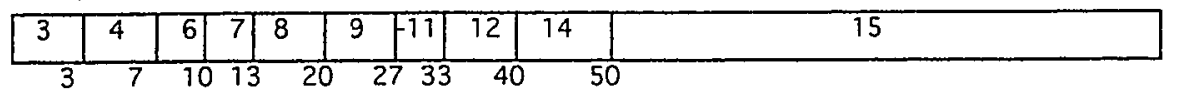

Kneel-Stand

\begin{tabular}{|l|l|l|}
\hline neither & only one & both \\
\hline 7 & & \\
\hline
\end{tabular}

Imi. of Post.

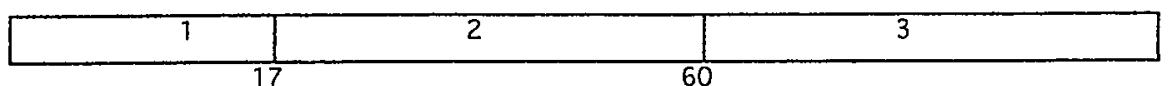

Tongue Mov.

\begin{tabular}{|l|l|}
\hline 2 & 3 \\
\hline 7 & 33
\end{tabular}

Rap. Alt. Mov.

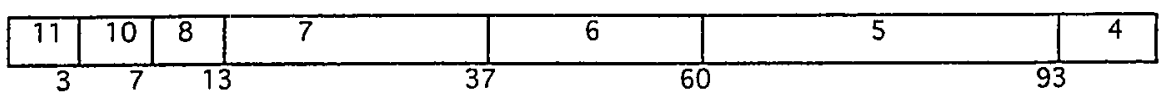

Maze

\begin{tabular}{|l|l|l|l|l|l|l|l|l|l|l|l|}
\hline unable $16-14$ & 13 & 11 & 10 & 9 & 8 & 7 & 6 & 5 & 4 \\
\hline 3
\end{tabular}

Gen. Inf.

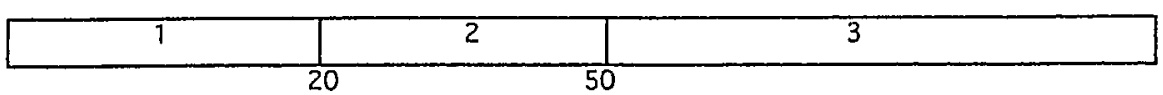

Follow Dir.

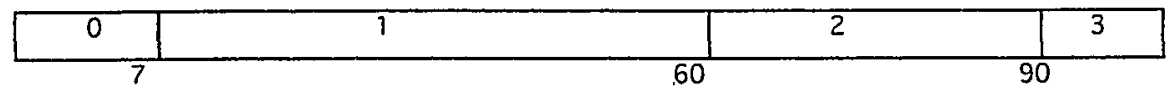

Articulation

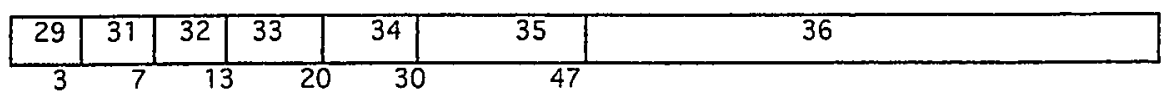

Sentence Rep. 2

Digit Rep.

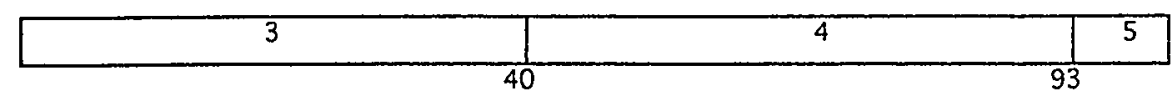


Figure A-5. Reference guide for item score sheet. Icelandic age group VIa $\left(5^{\prime} 3-5^{\prime} 8\right)$

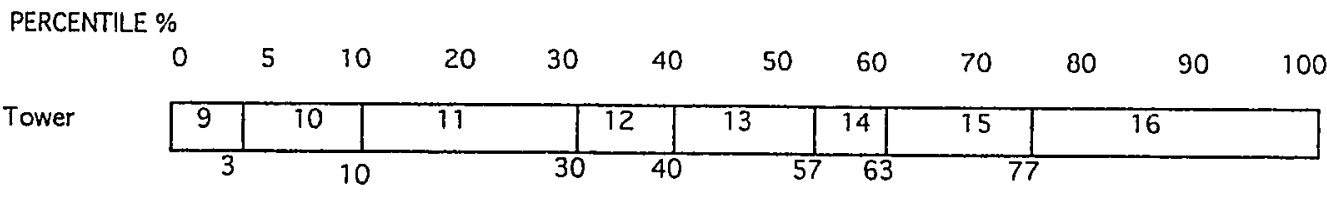

Sequencing \begin{tabular}{r|c|}
\hline fail & pass \\
\hline 3 &
\end{tabular}

Block Designs \begin{tabular}{r|r|r|}
\hline n.b.r. & miss airplane & both \\
\hline 3 & & 40
\end{tabular}

Block Tapping \begin{tabular}{|l|l|l|}
\hline$n \cdot$ & only one & both \\
\hline 3 & 13 &
\end{tabular}
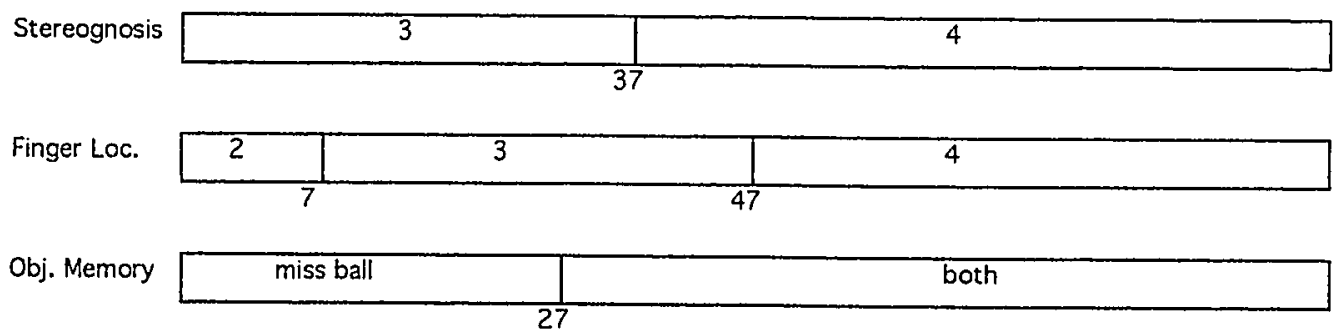

Puzzles

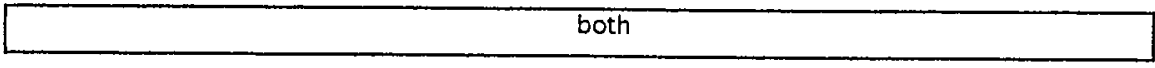

Fig.-Ground

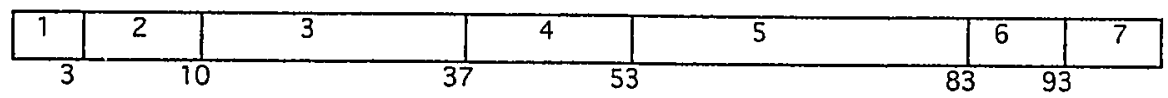

Draw-Person

\begin{tabular}{|l|r|r|r|r|r|r|r|r|r|r|r|}
\hline 9 & 10 & 11 & 12 & 13 & 14 & 15 & 16 & 17 & 18 & 20 & 27 \\
\hline
\end{tabular}

Motor Acc.

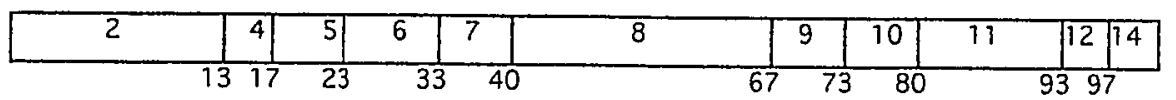

Vert. Writing

\begin{tabular}{|l|l|l|l|l|l|l|l|l|l|l|l|}
\hline 11 & 10 & 9 & 8 & 7 & 6 & 5 & 4 & 3 & 2 & 1 \\
\hline 3 & 7 & 10 & 17 & 23 & 33 & & 50 & & 70 & 83 & 90
\end{tabular}

Hand-Nose

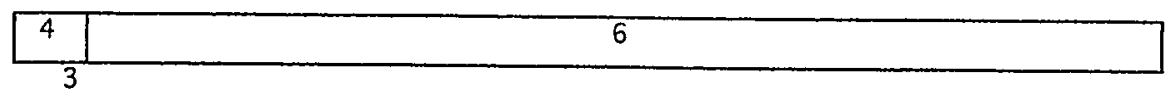

Romberg

\begin{tabular}{|l|l|l|l|l|l|l|l|l|l|l|}
\hline 1 & 2 & 3 & 4 & $5-6$ & 7 & 9 & 10 & 11 & 12 & 15 \\
\hline 3 & & & 3 & &
\end{tabular}


Figure A-6. Reference guide for item score sheet. Icelandic age group VIb $\left(5^{\prime} 3-5^{\prime} 8\right)$

PERCENTILE \%

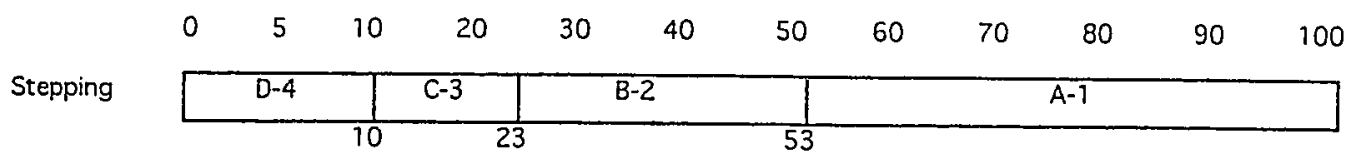

\begin{tabular}{|c|c|c|c|c|c|c|}
\hline Walks Line & Eun. & $\begin{array}{l}-44 \\
14 \\
\end{array}$ & \begin{tabular}{|c|c|c|}
$43-39$ & $38-31$ & 30 \\
$13-12$ & $17-9$ & 8 \\
\end{tabular} & $\frac{29-27}{7}$ & $\begin{array}{r}26-22 \\
6-5 \\
\end{array}$ & \begin{tabular}{l|l}
21 & 20 \\
4 & 4 \\
\end{tabular} \\
\hline
\end{tabular}

Sup. Flexion

\begin{tabular}{|c|c|c|c|c|c|c|c|c|}
\hline 3 & 6 & $7-8$ & 9 & $10-17$ & 12 & 13 & 14 & 15 \\
\hline 3 & & 10 & 17 & 24 & 31 & 45 & 52 & 62
\end{tabular}

Kneel-Stand

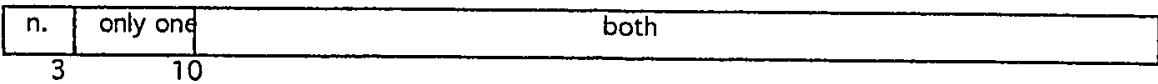

Imi. of Post.

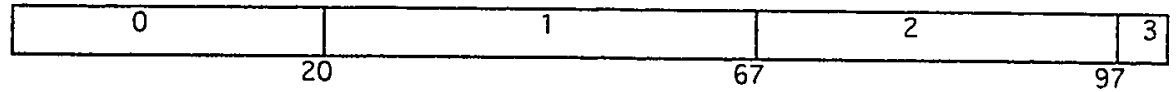

Tongue Mov.
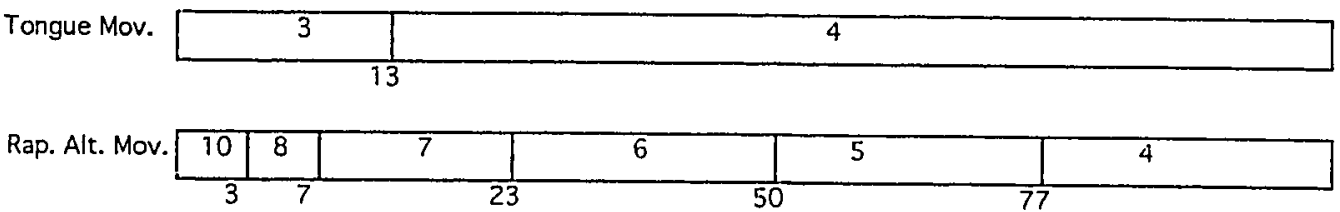

Maze

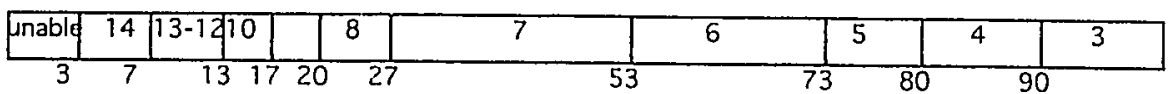

Gen. Inf.

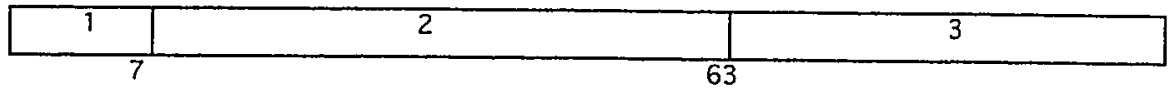

Follow Dir.

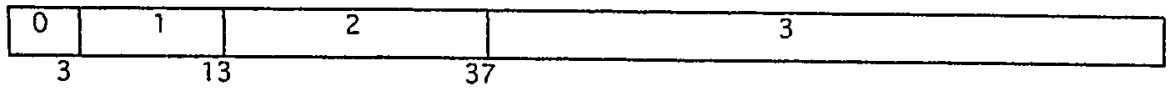

Articulation

\begin{tabular}{|l|l|l|l|l|l|l|}
\hline 30 & 31 & 33 & 34 & 35 & 36 \\
\hline 3 & 7 & 10 & 47 & & 73 \\
\hline
\end{tabular}

Sentence Rep.

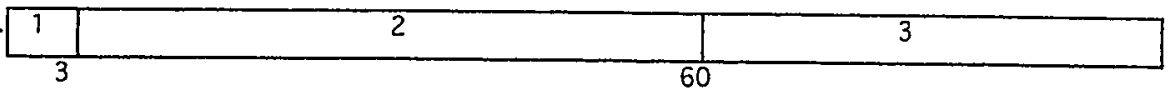

Digit Rep.

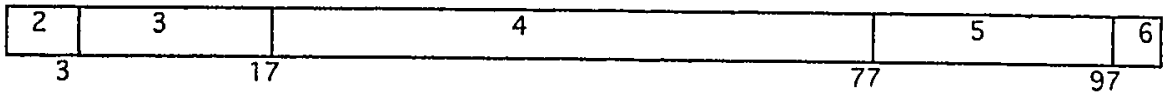


Figure A-7. Reference guide for item score sheet. U.S. age group Пa

$\left(3^{\prime} 3-3^{\prime} 8\right)$

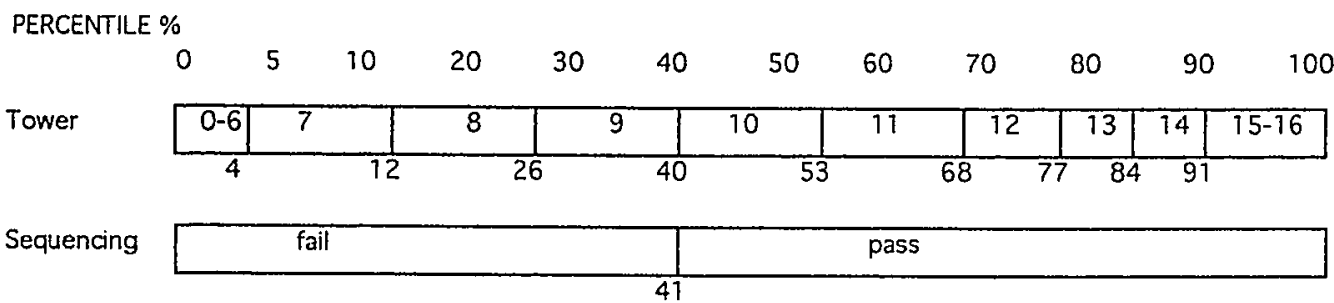

Block Designs \begin{tabular}{|l|l|l|l|}
\hline n. & only one & both \\
\hline 5 & 17
\end{tabular}

Block Tapping \begin{tabular}{|l|l|l|}
\hline neither & only one & both \\
\hline
\end{tabular}

Stereognosis \begin{tabular}{r|r|r|r|}
$0-2$ & 3 & 4 \\
\hline 4 & 15
\end{tabular}

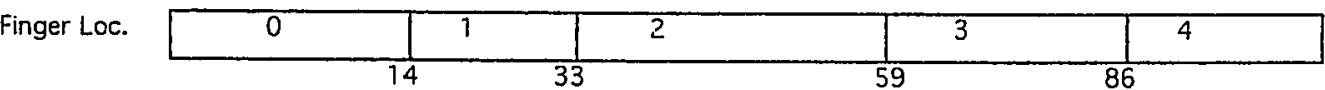

Obj. Memory \begin{tabular}{|l|l|r|rc|}
\hline neither & $\begin{array}{l}\text { m. } \\
\text { fork }\end{array}$ & miss ball & both \\
\hline 13 & 20 & 38
\end{tabular}

\begin{tabular}{|l|r|r|}
\hline neither & only one & both \\
\hline
\end{tabular}

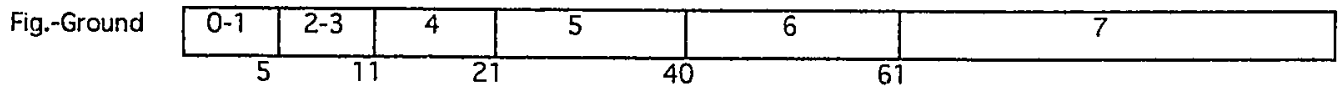

\begin{tabular}{rl|l|l|l|l|l|l|l|l|l|}
\hline Draw-Person & 0 & $1-2$ & 3 & 5 & 6 & 7 & $8-9$ & $10-37$ \\
\hline
\end{tabular}

\begin{tabular}{l|r|r|r|r|r|r|r|}
\hline Motor Acc. & 0 & 1 & 2 & 3 & $4-5$ & $6-13$ \\
\hline
\end{tabular}

Vert. Writing \begin{tabular}{|l|l|l|l|l|l|l|l|l|l|l|l|}
\hline Inable & $20-17$ & $16-13-10$ & 9 & $8-7$ & 6 & 5 & 4 & 3 & $2-7$ \\
\hline 5 & 10 & 1622 & 28 & 40 & 51 & 61 & 72 & 87 & \\
\hline
\end{tabular}

Hand-Nose \begin{tabular}{r|r|r|r|r|r|r|}
\hline 0 & $1-2$ & 3 & 4 & 5 & 6 \\
\hline
\end{tabular}

Romberg

\begin{tabular}{|l|l|l|l|}
\hline 0 & $7-9$ & -14 & 15 \\
\hline 3
\end{tabular}


Figure A-8. Reference guide for item score sheet. U.S. age group IIb $\left(3^{\prime} 3-3^{\prime} 8\right)$.

PERCENTILE \%

\begin{tabular}{|llllllllllllll}
0 & 5 & 10 & 20 & 30 & 40 & 50 & 60 & 70 & 80 & 90 & 100 \\
\hline unable & & $\mathrm{B}-3$ & $\mathrm{~A}-2$ & & & $\mathrm{~A}-1$ & \\
\hline
\end{tabular}

Waiks Line

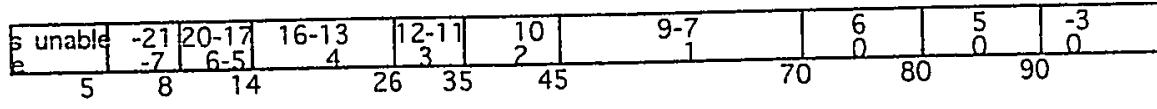

Sup. Flexion

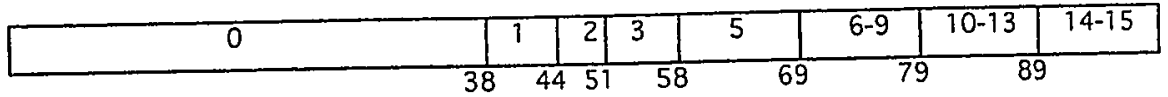

Kneel-Stand

\begin{tabular}{|l|r|r|}
\hline neither & only one & both \\
\hline 25 & 41
\end{tabular}

Imi. of Post.

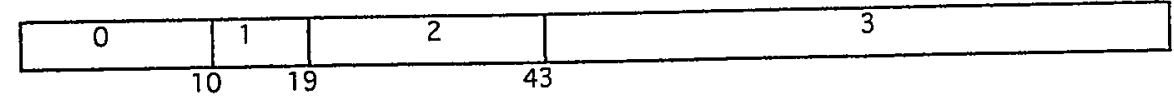

Tongue Mov.

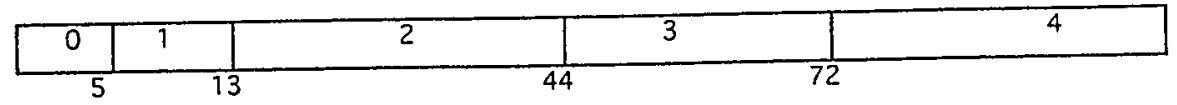

Rap. Alt. Mov.

\begin{tabular}{|l|c|c|c|c|c|c|c|}
\hline unable & 20 & $11-8$ & $9-8$ & 7 & 6 & 5 \\
\hline
\end{tabular}

Maze

\begin{tabular}{|l|r|r|r|r|r|r|r|r|r|}
\hline unable & $30-12$ & $11-9$ & $8-7$ & 6 & 5 & 4 & 3 & $2-1$ \\
\hline 7
\end{tabular}

Gen. Inf.

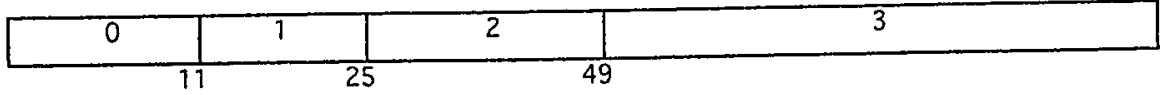

Follow Dir.

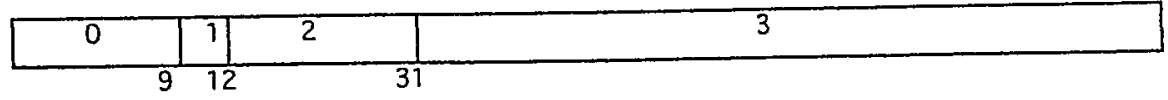

Articulation

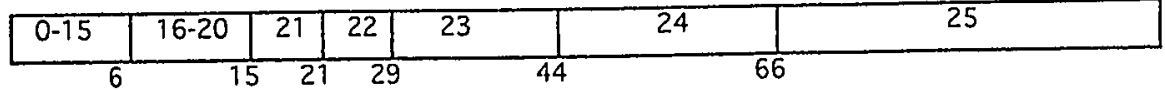

Sentence Rep

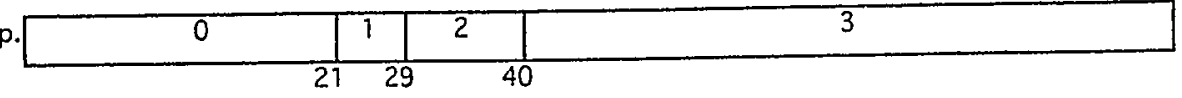

Digit Rep.
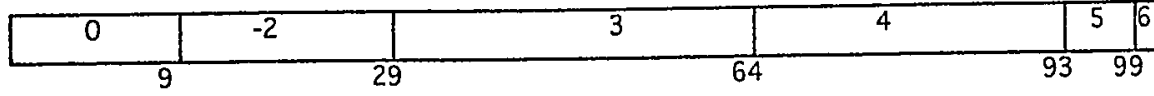
Figure A-9. Reference guide for item score sheet. U.S. age group IVa $\left(4^{\prime} 3-4^{\prime} 8\right)$.

PERCENTILE \%

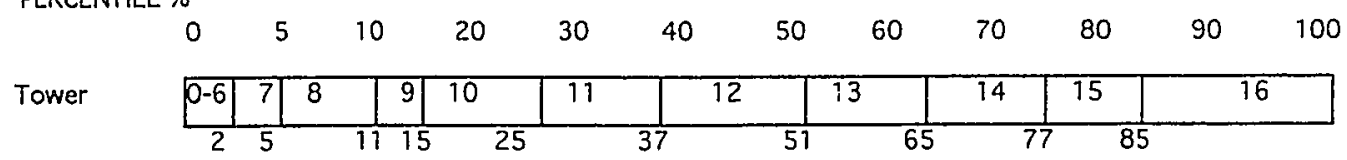

Sequencing

\begin{tabular}{|c|c|}
\hline fail & pass \\
\hline 27
\end{tabular}

Block Designs

\begin{tabular}{|r|r|r|r|r|}
\hline n. & m. house & miss stairs & both \\
\hline 1 & 12 & 28
\end{tabular}

Block Tapping

\begin{tabular}{l|l|l|l|}
\hline neither & only one & both \\
\hline 14 & 38
\end{tabular}

Stereognosis

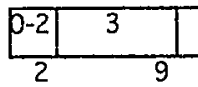

4

Finger Loc.

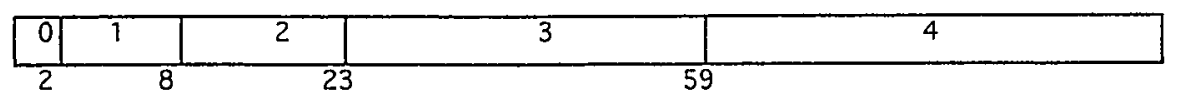

Obj. Memory

\begin{tabular}{|c|c|c|cc|}
\hline$n$. & $\begin{array}{c}\text { miss } \\
\text { fork }\end{array}$ & miss ball & both \\
\hline 3 & & & \\
\hline 10 & &
\end{tabular}

Puzzles

\begin{tabular}{|l|l|l|}
\hline neither & only one & both \\
\hline 11 & \multicolumn{2}{|c|}{24}
\end{tabular}

Fig.-Ground

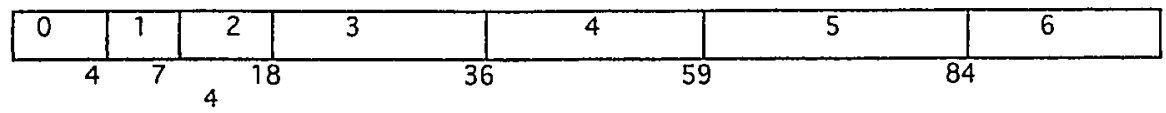

Draw-Person

\begin{tabular}{|l|l|l|l|l|l|l|l|l|l|l|l|l|l|}
\hline 0 & -3 & 4 & 5 & 6 & 7 & 8 & 9 & 10 & $11-12$ & $13-14$ & $15-17$ & $18-37$ \\
\hline 3 & 6 & 13 & 18 & 25 & & 33 & 40 & 47 & 56 & 69 & 80 & 89
\end{tabular}

Motor Acc.

\begin{tabular}{|l|l|l|l|l|l|l|l|l|l|l|l|}
\hline 0 & 1 & 2 & 3 & 4 & 5 & 6 & 7 & 8 & $9-11$ & $12-16$ \\
\hline
\end{tabular}

Vert. Writing

\begin{tabular}{|c|c|c|c|c|c|c|c|}
\hline \begin{tabular}{ll|} 
unabld & $12-9$ \\
$20-13$ &
\end{tabular} & 8 & 7 & 6 & 5 & 4 & 3 & 2 \\
\hline
\end{tabular}

Hand-Nose

\begin{tabular}{|l|l|l|l|l|l|}
\hline 0 & -2 & 3 & 4 & 5 & \\
\hline 2 & 4 & 7 & 10 & 16
\end{tabular}

Romberg

$$
\begin{array}{|l|l|l|}
\hline 0-6 & -10 & -14 \\
\hline 3 & 69
\end{array}
$$


Figure A-10. Reference guide for item score sheet. U.S. age group IVb $\left(4^{\prime} 3-4^{\prime} 8\right)$.

PERCENTILE \%

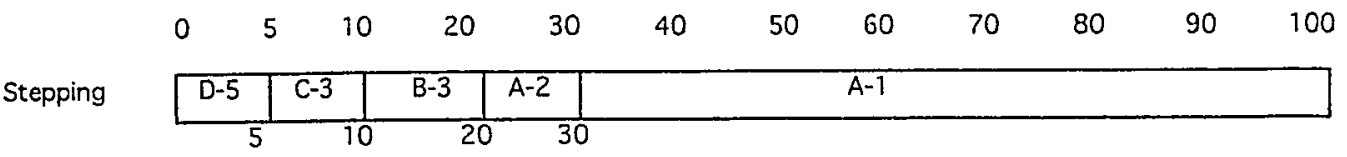

Walks Line

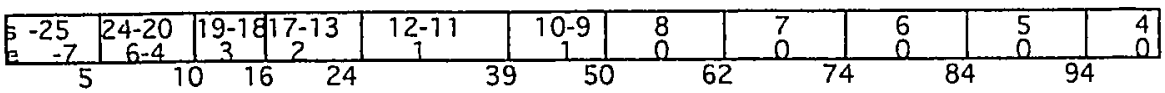

Sup. Flexion

\begin{tabular}{|l|l|l|l|l|l|l|l|l|l|l|l|}
\hline 0 & 7 & 2 & -4 & $5-6$ & 7 & $8-9$ & $10-11$ & $12-14$ & 15 \\
\hline 13 & 15 & 23 & 30 & 37 & 42 & 52 & 62 & 70
\end{tabular}

Kneel-Stand

\begin{tabular}{|l|l|l|}
\hline neither & only one & both \\
\hline 9 & 27
\end{tabular}

Imi. of Post.

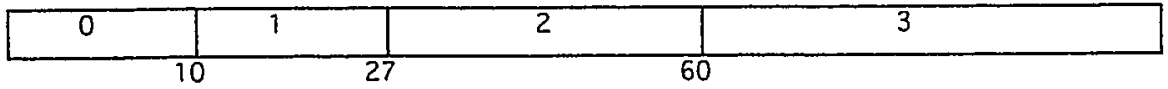

Tongue Mov. \begin{tabular}{|l|l|l|l|l|}
\hline 1 & 2 & 3 & 4 \\
\hline
\end{tabular}

Rap. Alt. Mov. \begin{tabular}{|l|l|l|l|l|l|l|l|l|l|}
\hline In. -11 & $10-9$ & 8 & 7 & 6 & 5 & 4 \\
\hline 2 & 5 & & &
\end{tabular}

Maze

\begin{tabular}{|c|c|c|c|c|c|c|c|c|}
\hline unable & $30-2322-1716-14$ & 13-12 & $71-10$ & $9-8$ & 7 & 6 & & $4-1$ \\
\hline
\end{tabular}

Gen. Inf.

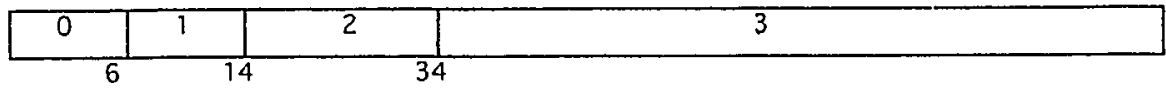

Follow Dir.

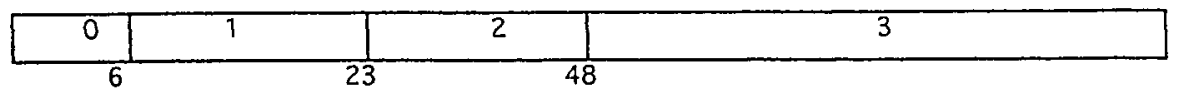

Articulation

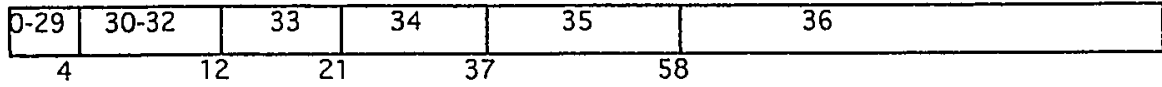

Sentence Rep

\begin{tabular}{|l|l|l|l|}
\hline 0 & 1 & 2 & 3 \\
\hline 12 & 19 & 33
\end{tabular}

Digit Rep.

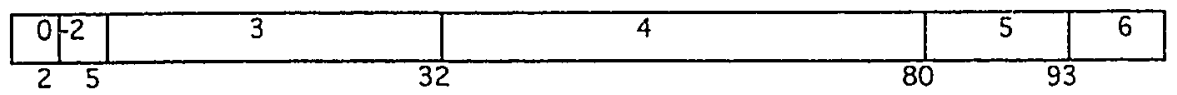


Figure A-11. Reference guide for item score sheet. U.S. age group VIa $\left(5^{\prime} 3-5^{\prime} 8\right)$.

$\begin{array}{rrrrrrrrrrrr}\text { PERCENTILE \% } \\ 0 & 5 & 10 & 20 & 30 & 40 & 50 & 60 & 70 & 80 & 90 & 100\end{array}$

Tower

\begin{tabular}{|l|l|l|l|l|l|l|l|l|l|}
\hline $0-8$ & 9 & 10 & 11 & 12 & 13 & 14 & 15 & 16 \\
\hline 3
\end{tabular}

Sequencing

\begin{tabular}{|c|c|}
\hline fail & pass \\
\hline \multicolumn{2}{|c|}{13} \\
\hline
\end{tabular}

Block Designs

\begin{tabular}{|c|c|c|}
\hline neither & \begin{tabular}{l|l} 
m.big & miss \\
rocked & airplane
\end{tabular} & both \\
\hline
\end{tabular}

Block Tapping

\begin{tabular}{|c|c|c|}
\hline neit. & only one & both \\
\hline 4 & 22 & \\
\hline
\end{tabular}

Stereognosis

\begin{tabular}{|l|l|l|l|}
\hline $0-1$ & 2 & 3 & 4 \\
\hline 3 & 8 & 41 & 4 \\
\hline
\end{tabular}

Finger Loc.

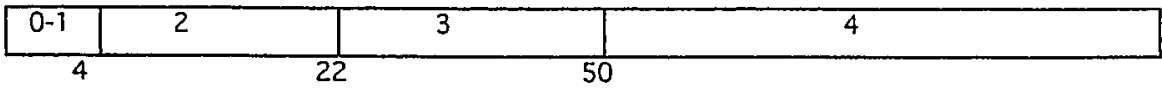

Obj. Memory

\begin{tabular}{|l|c|c|c|}
\hline$n$. & $\begin{array}{c}\text { miss } \\
\text { fark }\end{array}$ & miss ball & both \\
\hline 2 & & & \\
\hline
\end{tabular}

Puzzles

\begin{tabular}{|l|l|l|l|}
\hline neither & only & both \\
\hline
\end{tabular}

Fig.-Ground

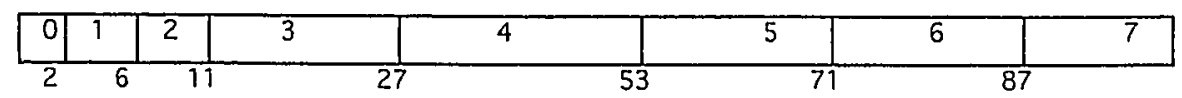

Draw-Person

\begin{tabular}{|l|c|c|c|c|c|c|c|c|c|c|c|c|}
\hline $0-7$ & 8 & 9 & 10 & 11 & 12 & 13 & 14 & 15 & $16-17$ & $18-19$ & $20-21$ & $22-37$ \\
\hline 4 & 8 & 14 & 19 & 23 & 29 & 36 & 45 & 53 & 65 & 77 & 90
\end{tabular}

Motor Acc.

\begin{tabular}{|c|c|c|c|c|c|c|c|c|c|c|}
\hline $0-2$ & 3 & 4 & 5 & 6 & 7 & 8 & $9-10$ & 11 & $12-13$ & $14-20$ \\
\hline 4 & 7 & 14 & 22 & 32 & 45 & 60 & & 76 & 85 & 93
\end{tabular}

Vert. Writing

\begin{tabular}{|l|l|l|l|l|l|l|l|l|}
\hline \hline $\mid 20-11$ & $10-8$ & 7 & 6 & 5 & 4 & 3 & 2 & 1 \\
\hline 1 & 5 & 14 & 21 & & 35 & 44 & 58 &
\end{tabular}

Hand-Nose

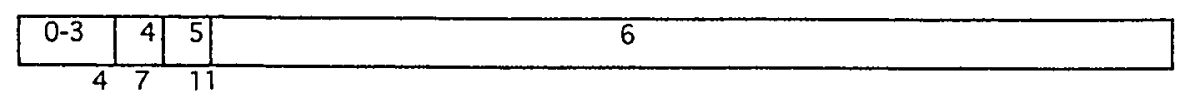

Romberg

\begin{tabular}{|l|l|l|l|l|l|l|l|l|}
\hline 0 & 1 & 2 & 3 & 4 & 5 & $6-7$ & $8-14$ & 15 \\
\hline
\end{tabular}


Figure A-12. Reference guide for item score sheet. U.S. age group VIb $\left(5^{\prime} 3-5^{\prime} 8\right)$.

\begin{tabular}{|c|c|c|c|c|c|c|c|c|c|c|c|c|}
\hline \multicolumn{13}{|c|}{ PERCENTILE \% } \\
\hline & 0 & 5 & 10 & 20 & 30 & 40 & 50 & 60 & 70 & 80 & 90 & 100 \\
\hline Stepping & $D-4$ & & $\mathrm{C}-3$ & $\mathrm{~B}-2$ & \multicolumn{8}{|c|}{$A-1$} \\
\hline
\end{tabular}

\begin{tabular}{l} 
Walks Line \begin{tabular}{|l|l|l|l|l|l|l|l|l|l|l|l|}
\hline un. & -44 & $43-39$ & $38-37$ & $30-27$ & $26-22$ & $21-29$ & $19-18$ & $17-15$ & 14 & $13-9$ & $8-3$ \\
\hline
\end{tabular} \\
\hline
\end{tabular}

Sup. Flexion

\begin{tabular}{|l|l|l|l|l|l|r|r|r|}
\hline $0-1$ & 2 & $3-5$ & 6 & 7 & $8-9$ & $10-12$ & $13-14$ & 15 \\
\hline 7 & 9 & & & &
\end{tabular}

Kneel-Stand

\begin{tabular}{|c|c|c|}
\hline neither & only one & both \\
\hline 4 & 17
\end{tabular}

Imi. of Post.

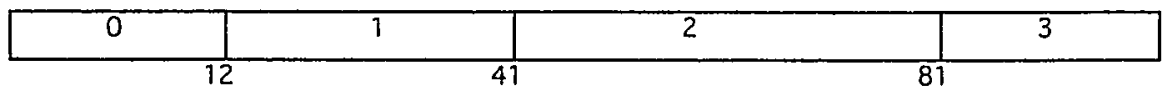

Tongue Mov. \begin{tabular}{|l|l|l|l|l|}
\hline$p-7$ & 2 & 3 & 4 \\
\hline 2 & & 10 & 27 \\
\hline
\end{tabular}

Rap. Alt. Mov. \begin{tabular}{|l|l|l|l|l|l|l|l|}
\hline $11+$ & 8 & 7 & 6 & 5 & 4 & 3 \\
\hline 4
\end{tabular}

Maze

\begin{tabular}{|l|l|l|l|l|l|l|l|l|l|l|}
\hline 5 & $30-15$ & $14-13$ & $12-11$ & 10 & $9-8$ & 7 & 6 & 5 & 4 & $3-1$ \\
\hline
\end{tabular}

Gen. inf.

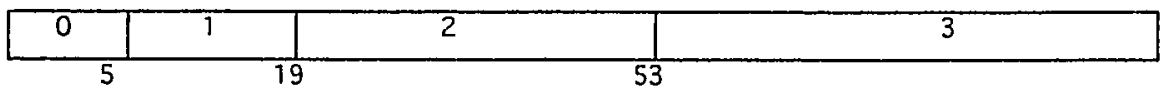

Follow Dir.

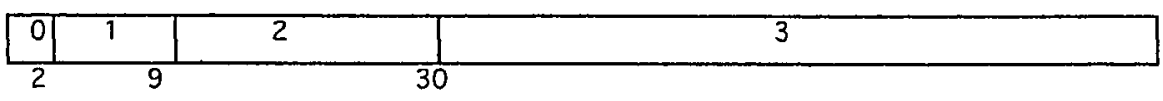

Articulation

\begin{tabular}{|l|l|l|l|l|l|l|}
\hline $0-31$ & 32 & 33 & 34 & 35 & 36 \\
\hline 6 & 12 & 20 & 34 & 53 & 35 \\
\hline
\end{tabular}

Sentence Rep. \begin{tabular}{|l|l|l|l|}
\hline 0 & 1 & 2 & 3 \\
\hline 2 & 14 & 50
\end{tabular}

Digit Rep.

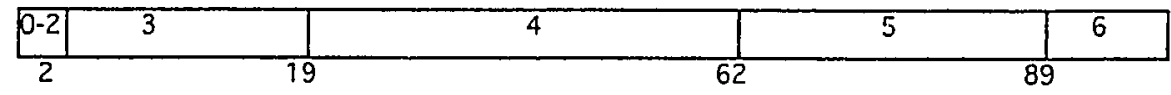




\section{APPENDIX B}

\section{Consent for research at facility}


To whom it may concern:

This is to certify that Snaefridur Thora Egilson, graduate student in Occupational Therapy, will gather data for her study:

"Comparison of the Norms of Icelandic Children to the Norms of U.S. Children on the Miller Assessment. for Prescholler: Pilot Study"

at this institution in August/September of this year.

The subjects are healthy Icelandic preschoolers.

The planning and implementation of the study are in full accordance with the standards of the institution.

Respectfully.

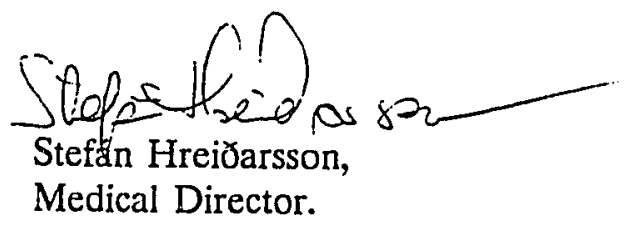




\section{APPENDIX C}

Informed consent for subjects 
College of Applied Sciences and Arts - Department of Occupational Therapy One Washington Square • San José, California 95192.0059

Main Olfice: 408/924-3070 • Fieldwork Office: 408/924-3078 • FAX: 408/924-3088

Consent form

\section{AGREEMENT TO PARTICIPATE IN RESEARCH} Responsible Investigator: Snaefridur Thora Egilson

Title of Protocol: Comparison of the norms of Icelandic children to the norms of U.S. children on the Miller Assessment for Preschoolers: A Pilot Study.

1. My child has been asked to participate in a research study comparing the norms for Icelandic and U.S. children on a scale used to evaluate preschoolers. (The Miller Assessment for Preschoolers - MAP).

2. The Miller Assessment for Preschoolers (MAP) will be administered to my child at the State Diagnostic and Counselling Center or at his/her preschool setting in August, 1993.

3. There is only minimal risk anticipated in participating in the study, no greater than encountered in daily life.

4. There are no benefits expected to my child from this study.

5. Although the results of the study may be published, the name of my child will not be used to identify the results of the investigation.

6. Questions about the research may be adressed to the principal investigator (901-408-725-8221. USA or 91-641744 Iceland). Complaints about the research may be presented to the respective Department Chair, (Lela A. Llorens, Ph.D. OTR, FAOTA, 901-408-924-3070) Questions or complaints about the research, subjects' rights, or research-related injury may be presented to Serena Stanford, Ph.D., Associate Vice President of Graduate Studies and Research, at (901-408-924-2480).

7. I understand that I will be asked to fill out forms with biographical information and answer questions regarding the health of my child.

8. My child may have the opportunity to participate in a follow up study, if this will be performed at a later time. 
9. My child is free to discontinue participation at any time during the study.

10. This consent is given voluntarily.

11. I have received a signed and dated copy of this consent form.

$\overline{\text { Parent's signature }}$

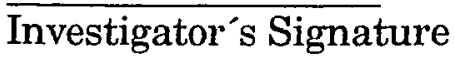

Date

Date 
College of Applied Sciences and Arts - Department of Occupallonal Therapy

One Washıngton Square • San Jose, Calitornia 95192-0059

Main Oltice: 408/924-3070 - Fieldwork Office: 408/924-3078 - FAX: 408/924-3088

\section{SAMPYKKI Á ĐÁTTTÖKU İ RANNSÓKN \\ Rannsólnarađili: Snæfriơur Dóra Egilson.}

Heiti rannsóknar: Samanburoarrannsókn á broskaprófi Miller fyrir forskólabörn.

1. Óskaớ hefur verið eftir að barniơ mitt taki pátt í samanburơarrannsókn á proskaprófi Miller fyxir forskólabörn.

2. Proskapróf Miller fyrir forskólabörn verour lagt fyrir barnið mitt á leikskóla bess eđa á Greiningar- og Ráogjafarstöđ Ríkisins síðari hluta ágústmảnađar eđa í byrjun september næstkomandi.

3. Ekki er talin nein áhætta samfara bátttöku i prófinu umfram pađ sem ætla má i daglegu lífi.

4. Barnið mitt mun ekki hafa beinan ágóõa af rannsókninni.

5. Prátt fyrir ađ̃ niðurstaõa rannsóknarinnar verõi kunngerð, pá mun nafn barnsins hvergi koma fram.

6. Upplýsingar um rannsóknina veitir Snæefriour Póra Egilson, iojjupjálfi á Greiningar- og Ráđgjafarstöđ Ríkisins (s. 641753). Hægt er að koma athugasemdum eða kvörtunum ef einhverjar eru, á framfæri vió Dr. Lelu A. Llorens deildarforseta ijjupjálfunardeildar háskólans í San Jose (sími 901-408-924-3070) eða til Dr. Serenu Stanford varaforseta deildar um framhaldsnám og rannsóknir (simi 901-408. 924-2480).

7. Mér er ljóst aơ ég mun verõa beđin(n) um ađ veita upplýsingar um eigin menntun og starf, svo og heilsufar barnsins míns.

8. Verōi rannsókninni fylgt eftir si̊đar meir, getur komið til bess að̃ haft verơi samband vió okkur á ný.

9. Barnid mitt getur hætt pátttöku i rannsókninni hvenær sem ég óska eftir bvi.

10. Sampykki petta er veitt af fúsum og frjálsum vilja. 
11. Ég hef fengið í hendur undirritað og dagsett afrit af pessu bréfi.

Undirskrift foreldris

Undirskrift iojubjálfa
Dagsetning

Dagsetning 
APPENDIX D

Developmental history 


\section{Developmental History}

(to be completed by parents)

Previous pregnancies

Pregnancy and birth

\section{Number:}

Problems $(\mathrm{J} / \mathrm{N})$ :

History of pregnancy with this child:

Health of mother (good/not good):

Use of medication $(\mathrm{J} / \mathrm{N})$ :

Length of pregnancy (number of weeks):

Complications during pregnancy $(\mathrm{J} / \mathrm{N})$ :

What kind:

Labor and delivery:

Natural (vaginal) $(\mathrm{J} / \mathrm{N})$ :

Use of forceps $(J / N)$ :

Length of labor (hrs):

Caesarean section $(\mathrm{J} / \mathrm{N})$ :

Other complications in relation to labor or delivery $(\mathrm{J} / \mathrm{N})$ :

What kind:

\section{EARLY HISTORY}

Condition of newborn:

Weight (gr.):

Length $(\mathrm{cm})$ :

Breathed immediately $(\mathrm{J} / \mathrm{N})$ :

Cried immediately $(\mathrm{J} / \mathrm{N})$ :

Other Comments:

\section{Feeding:}

Did your child have any difficulty sucking as an infant $(J / N)$ :

Was he/she breastfed $(\mathrm{J} / \mathrm{N})$ :

Did he/she repond well to solid food: $(\mathrm{J} / \mathrm{N})$ : 
Other comments:

\section{Sleeping patterns:}

Did your child sleep well as an infant $(\mathrm{J} / \mathrm{N})$ :

Other comments:

Activity level:

Was the child relatively calm or did he/she require a lot of attention. Describe briefly:

Toilet training:

How old was your child when he/she was toilet trained:

Any problems regarding toilet training $(\mathrm{J} / \mathrm{N})$ :__ What kind:

Medical history:

Frequent hospitalization $(\mathrm{J} / \mathrm{N})$ :

Reasons:

Allergies or Asthma $(\mathrm{J} / \mathrm{N})$ :

Ear infections $(\mathrm{J} / \mathrm{N})$ :

Other problems $(\mathrm{J} / \mathrm{N})$ :

What kind:

Developmental milestones:

How old was the child when he/she could:

sit alone

crawl

stand alone

walk first words 2-word sentence

3- to 4-word sentences ask questions drink from a cup

dress self

use spoon

use knife

run 
Any unusual behaviors or problems:

Head banging $(\mathrm{J} / \mathrm{N})$ :

Temper tantrums $(\mathrm{J} / \mathrm{N})$ :

Breath holding $(\mathrm{J} / \mathrm{N})$ :

Other:

\section{PRESENT STATUS}

Health:

Has the child been healthy the last few months $(J / N)$ :

If not, note frequency and type of illnesses:

Use of medecine $(\mathrm{J} / \mathrm{N})$ :

What kind of medecine:

Sleep:

Length of sleep: (hrs. pr. night)

Comments on sleeping habits:

Eating patterns:

Does your child eat a variety of food $(J / N)$ :

Are there any problems regarding eating habits $(\mathrm{J} / \mathrm{N})$ :

What kind:

Activity level/Behavior

Is your child relatively calm or very active? Describe briefly:

Does your child seem to be generally happy $(J / N)$ :

Does he/she require a lot of your attention $(\mathrm{J} / \mathrm{N})$ :

Interaction with other children

Does your child prefer playing with:

Own age: ___ Older cildren: ___ _ _ Younger children: 
Does your child make friends easily $(\mathrm{J} / \mathrm{N})$ :

Does your child frequently fight with other children $(\mathrm{J} / \mathrm{N})$ :

Play and leisure:

Does your child show interest in variety of play $(\mathrm{J} / \mathrm{N})$ :

What kind of toys or play does the child prefer:

Does he/she like to watch televison $(\mathrm{J} / \mathrm{N})$ :___ Daily hrs:

Daycare:

Does your child attend preschool or other type of daycare $(J / N)$ :

Hrs. per week:

Describe coordination:

Describe language:

Note any problems:

Note if siblings or close relatives have/had problems in school, or with learning in general $(\mathrm{J} / \mathrm{N})$ :

What kind of problems: 


\section{Biographical Information Sheet for Completition by Parents}

1. Mother's Education:

less than 8 years

10 years (elem. education)

- 1-3 years in high school

high school graduate

1-3 years in college

college graduate
Father's Education:

less than 8 years

10 years (elem. education)

1-3 years in high school

high school graduate

$1-3$ years in college

college graduate

2. Mother's Occupation:

Father's Occupation:

3. Marital Status:

Parents married/living together $(\mathrm{J} / \mathrm{N})$ :- $\operatorname{single}$ parent $(\mathrm{J} / \mathrm{N})$ :-

4. History of Family during the Last Year:

Moves $(J / N)$ :

Significant traumas or emotional upsets $(\mathrm{J} / \mathrm{N})$ :

Other changes $(\mathrm{J} / \mathrm{N})$ :

What kind:

5. Community Size:

More than 30,000

$10,000-29,999$

$500-2,499$

$2,500-9.999$

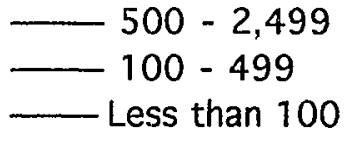




\section{Proskasaga}

(fyllist út af foreldrum)

\section{MEDGANGA OG FAEĐING}

Fyrri meőgöngur:

Fjöldi:

Með̃ganga barnsins:

Heilsa móður (góð/erfið):

Meðgöngulengd (vikufjöldi):

Voru erfiðleikar eð̃a vandamál tengd meðgöngu $(\mathrm{J} / \mathrm{N})$ :

Hver:

\section{Fæơing:}

Eðlileg $(\mathrm{J} / \mathrm{N})$ : Notkun tanga eða sogklukkna (J/N):

Fæð̌ingartími i klst: Keisaraskurður (J/N):

Voru að̌rir erfiðleikar eða vandamál tengdir fæðingu barnsins $(\mathrm{J} / \mathrm{N})$ :

Hverjir:

\section{FYRSTU MÁNUĐIR OG ÁR}

Ástand barnsins við fæoðingu:

pyngd (merkur):

Lengd $(\mathrm{cm})$ :

Andað̌i strax (J/N):

Grét strax $(\mathrm{J} / \mathrm{N})$ :

Annað:

\section{Matargjöf:}

Tók barnið vel við̃ brjósti eða pela $(J / N)$ :

Tók barnið siðar vel við annarri fæðu $(\mathrm{J} / \mathrm{N})$ : 
Annað:

Svefnvenjur:

Svaf barnið vel $(\mathrm{J} / \mathrm{N})$ :

Annað:

Virkni:

Var barnið yfirleitt rólegt eða var pað fyrirferðamikið. Lýsiơ stuttlega:

Prifapjálfun:

Hve gamalt var barnið pegar pað̃ var vanið af bleyju:

Voru vandamál við prifapjálfun $(\mathrm{J} / \mathrm{N})$ :

Hver:

Heilsufarssaga:

Tỉar sjúkrahúsdvalir $(\mathrm{J} / \mathrm{N})$ :

Ástæða:

Ofnæmi eða Asthmi (J/N):

Eyrnabólgur (J/N):

Önnur heilsufarsvandamál $(\mathrm{J} / \mathrm{N})$ :

Hver:

\section{proskaferill:}

Hvað var barnið gamalt pegar pað gat:

setið óstutt sagt fyrstu orðin

drukkiơ úr bolla

skriðið

2ja orða setningar

klætt sig sjálft

stað̌ið̌ óstutt

3ja-4urra orða setningar

borðað̃ með̃ skeið̃

gengið

spurt spurninga

notað̃ hnif

hlaupið 
Óvenjuleg hegðun eða vandamál:

Barði við höfði $(\mathrm{J} / \mathrm{N})$ :

Reið̌iköst $(\mathrm{J} / \mathrm{N})$ :

Stóð á öndinni $(\mathrm{J} / \mathrm{N})$ :

Annað:

\section{STAĐA MÁLA İ DAG}

\section{Heilsufar:}

Hefur barnið verið við góða heilsu undanfarna mánuð̃i $(\mathrm{J} / \mathrm{N})$ :

Ef ekki, nefnið̋ tiôni og tegund veikinda:

Notkun lyfja $(\mathrm{J} / \mathrm{N})$ :

Hvaða lyf:

Svefn:

Svefniengd: (klst. á nóttu)

Annað̃ um svefnvenjur barnsins:

Matarvenjur:

Borðar barnið fjölbreyttan mat $(\mathrm{J} / \mathrm{N})$ :

Eru vandamál tengd matarvenjum eða borðhaldi $(\mathrm{J} / \mathrm{N})$ :

Hver:

Virkni:

Er barnið rólegt að eðlisfari eða mikið fyrir sér? Lýsið̃ stuttlega:

Er barnið̌ yfirleitt í góðu jafnvægi (J/N):

Krefst barnið mikillar athygli $(\mathrm{J} / \mathrm{N})$ :

Samskipti viő önnur börn:

Kýs barnið̋ að̃ leika við: Jafnaldra: Eldri börn:___ Yngri börn:

Á barnið̌ auð̃velt með̊ að̃ eignast vini $(\mathrm{J} / \mathrm{N})$ : 
Lendir barnið oft í útistöðum við̃ leikfélaga $(\mathrm{J} / \mathrm{N})$ :

Leikur og tómstundir:

Við hvað unir barnið sér best:

Sýnir barnið fjölbreytni i leik $(J / N)$ :

Horfir pað̃ mikið á sjónvarp $(\mathrm{J} / \mathrm{N})$ :

Dagvist:

Er barnið̃ á leikskóla eða í annarri dagvist $(\mathrm{J} / \mathrm{N})$ :

Hve lengi á dag:

Lýsið stuttlega hreyfifærni barnsins:

Lýsið̌ stuttlega hvernig barnið̋ tjáir sig:

Nefnið̃ vandamál ef einhver eru:

Eiga nánir æettingjar eiga við̌ fötlun og/eð̃a vandamál i skóla að striða, t.d. við lestur eð̆a skrift? $(\mathrm{J} / \mathrm{N})$ :

Hvers konar vandamál: 


\section{Bakgrunnsupplýsingar}

(fyllist út af foreldrum)

1. Menntun móður

Minna en grunnskólapróf Grunnskólapróf

1-3 ár i framhaldsskóla

Stúdentspróf eða samsvarandi

1-3 ár i háskóla

Háskólapróf
Menntun föður

Minna en grunnskólapróf

Grunnskólapróf

1-3 ár í framhaldsskóla Stúdentspróf eða samsv.

1-3 ár î háskóla Háskólapróf

\section{Starf móơur}

Starf föður

\section{Hjúskaparstaða:}

Foreldrar i sambúð (J/N): Einstætt foreldri (forráðamaður barnsins)

4. Fjölskylduað̌stæður síð̆asta áriơ:

Flutningar $(\mathrm{J} / \mathrm{N})$ :

Erfiơleikar eða stóráföll (J/N):

Aðrar breytingar (J/N):

Hverjar:

5. Búseta/stærõ bæjarfélags:

Fleiri en 30.000

$10.000-29.999$

$500-2.499$

$2.500-9.999$

$100-499$

Minna en 100 
APPENDIX E

Letter to parents 
July, 1993

Dear Parent.

This letter is written in response to our conversation about a study on the "Miller Assessment for Preschoolers." As I explained to you, your child was chosen as one of 90 children on a random list from the Icelandic Census Bureau. As you kindly agreed to participate in the study, I would like to ask you to fill out the enclosed forms:

* A consent form to confirm that you agree to participate in the study. There are two copies of this form. I would like you to keep one but send the other one back to me with your signature on it.

* A list of questions regarding the child's health and some biographical information.

Enclosed is an adressed stamped envelope, so you can get the information back to me as soon as possible.

As I stated in our conversation, all information will be kept strictly confidential and the name of your child will never appear, while or after the study.

If you want some more information about the study, I or my colleague, Hlín Guơjónsdóttir would be glad to provide it.

Thank you for your cooperation,

Snæfrífur Póra Egilson, Occupational Therapist, State Diagnostic and Councelling Center, Digranesvegi 5, 200 Kópavogi.

Sími: 641744 
Júlí, 1993.

Ágæta foreldri.

Petta bréf er ritađ í framhaldi af samtali um fyrirhugađa rannsókn á proskaprófi Miller. Eins og bar kom fram, var nafn barns bíns eitt af 90 nöfnum er dregin voru út i tilviljunarúrtaki vegna rannsóknarinnar. Par eđ pú hefur góðfúslega fallist á ađ barnið taki pátt í rannsókninni, vil ég senda pér eftirtalin gögn, sem pú ert vinsamlegast beơin(n) um ađ fylla út:

* Eyoublađ til að stađfesta að bú sambykkir bátttöku. Eyðublaðið er í tvíriti og vil ég biðja pig um aơ halda öđru eftir, en senda hitt til baka međ undirskrift pinni.

* Spurningalisti um heilsufarssögu barnsins og um menntun og störf foreldra.

ছessar upplýsingar eru nauð̌synlegar vegna rannsóknarinnar og verđur farið međ bær sem trúnađarmál. Đú ert vinsamlegast beđin(n) um að senda pær til baka hið fyrsta í međfylgjandi frímerktu umslagi.

Eins og áđur hefur komið fram verđur gatt fyllstu nafnleyndar og mun nafn barnsins hvergi koma fram, hvorki međan á rannsókn stendur né eftir á. Óskir bú frekari upplýsinga, pá mun ég eđa Hlín Guđjónsdóttir iơjubjálfí á Greiningar- og Ráđgjafarstöð Rỉisins, veita bær fúslega.

Með kærri kveđju og fyrirfram pökk fyrir veitta aðstoð,

Snæfríður Póra Egilson, iojubjálfi Greiningar- og Ráđgjafarstöđ Ríkisins, Digranesvegi 5, 200 Kópavogi.

Sími: 641744 


\section{APPENDIX F}

Draft for phone conversation with parents 


\section{Draft for phone conversation with parents}

Good afternoon!

My name is Snæfrídur Póra Egilson and I am an occupational therapist at the State Diagnostic and Councelling Center.

The reason for this call is that your child has been chosen from a random list from the Icelandic Census bureau, to participate in a study on a developmental assessment for preschoolers (Miller Assessment for Preschoolers) The study is conducted in participation with this institution and it is a part of the requirements for my Master's study at San Jose State University in California, USA.

This assessment has been used in Iceland for 6 years, and has already been administered to hundreds' of Icelandic children. The test consists of simple tasks and games and it is designed to assess a broad range of domains, including motor, sensory and cognitive domains.

Administration time is aproximately $\mathbf{4 0}$ minutes. The purpose of this study is to determine whether or not the U.S. norms that we have been using, are applicable to Icelandic children.

So, I would like to ask for your permission to test (name of child). $\mathrm{He} / \mathrm{she}$ would be one out of $\mathbf{9 0}$ children in the capital area to take the test. The test can be administered at the child's preschool setting or here at the State Diagnostic and Councelling Center, Digranesvegur 5 in Kópavogur, according to your convenience. All information will be kept strictly confidential and the name of your child will never appear, neither during nor after the study.

Participation is on a voluntary basis. If you agree to participate, I 
will send you a packet including the following forms:

* A consent form to confirm that you agree to participate in the research.

There are two copies of this form and I would like to ask you to keep one but send the other one back to me with your signature on it.

* A list of questions about the child's health and about parent's background.

This information is necesseary to the research and will be treated confidentially.

You will also get a self adressed stamped envelope so you can get the information back to me in a convenient way. If you want some more information about the study, I would be glad to provide it. 


\section{Drög að símtali við foreldra}

Ég heiti Snæfiriđur Póra Egilson og er iðjubjálfi við Greiningar- og Ráđgjafarstöđ Ríkisins.

Ástæða bess að ég hef samband við big er sú að barnið bitt, hefur verio valiơ til páttöku í

samanburđarrannsókn á broskaprófi (Miller) fyrir forskólabörn.

Rannsóknin er hluti af Mastersverkefni mínu við háskólann í San Jose í Kaliforníu.

Petta proskapróf hefur verið notađ á Íslandi í 5 ár og hefur bað begar veriơ lagt fyrir fjöldamörg börn. Prófiơ samanstendur af einföldum verkefnum og leikjum og er bví aðallega ætlað að meta hreyfifærni og skynjun hjá forskólabörnum. Próftími er u.p.b. 40 mínútur. Međ bessari rannsókn á að athuga hvort ađ bandarískar viðmiðanir, sem við höfum notast við til pessa, eru marktækar fyrir íslensk börn.

Ég vil bví leita eftir leyfi pínu til að fá að prófa sem eitt af 90 börnum af höfuðborgarsvæđinu, sem taka betta próf. Prófið verđur lagt fyrir samkvæmt samkomulagi annađ hvort á leikskóla barnsins, eđa hér á Greiningar- og Ráđgjafarstöđ Ríkisins, Digranesvegi 5 í Kópavogi. Ғađ verđur gætt fyllstu nafnleyndar við rannsóknina og nafn barnsins mun hvergi koma fram, hvorki međan á rannsókn stendur né eftir á.

Dáttaka er algerlega frjáls. Ef bú sampykkir páttöku pá mun ég senda bér eftirfarandi gögn til að fylla út:

* Eyđublað til ađ̃ stađfesta ađ pú sampykkir pátttöku.

* Spurningalista um heilsufarssögu barnsins, og um menntun og störf foreldra. 
Dessar upplýsingar eru nauđsynlegar vegna rannsóknarinnar en farið verður með bær sem trúnaðarmál. Pú færð jafnframt sent merkt umslag međ frímerki, pannig að bú getir komið upplýsingunum á sem auđveldastan hátt aftur til mín.

Ef pú vilt fá frekari upplýsingar um rannsóknina, bá veiti ég bær fúslega. 